\title{
Caustic Leaching of SRS Tank 12H Sludge With and Without Chelating Agents
}

\section{April 2003}

Prepared by

B. B. Spencer

J. L. Collins

R. D. Hunt 
This report has been reproduced from the best available copy.

Reports are available to the public from the following source.

National Technical Information Service

5285 Port Royal Road

Springfield, VA 22161

Telephone 703-605-6000 (1-800-553-6847)

TDD 703-487-4639

Fax 703-605-6900

E-mail orders@ntis.fedworld.gov

Web site http://www.ntis.gov/ordering.htm

Reports are available to U.S. Department of Energy (DOE) employees, DOE contractors, Energy

Technology Data Exchange (ETDE) representatives, and International Nuclear Information

System (INIS) representatives from the following source.

Office of Scientific and Technical Information

P.O. Box 62

Oak Ridge, TN 37831

Telephone 865-576-8401

Fax 865-576-5728

E-mail reports@adonis.osti.gov

Web site http://www.osti.gov/products/sources.html

Reports produced after January 1, 1996, are generally available via the DOE Information Bridge. Web site http://www.doe.gov/bridge

This report was prepared as an account of work sponsored by an agency of the United States government. Neither the United States government nor any agency thereof, nor any of their employees, makes any warranty, express or implied, or assumes any legal liability or responsibility for the accuracy, completeness, or usefulness of any information, apparatus, product, or process disclosed, or represents that its use would not infringe privately owned rights. Reference herein to any specific commercial product, process, or service by trade name, trademark, manufacturer, or otherwise, does not necessarily constitute or imply its endorsement, recommendation, or favoring by the United States government or any agency thereof. The views and opinions of authors expressed herein do not necessarily state or reflect those of the United States government or any agency thereof. 
ORNL/TM-2002/195

Nuclear Science and Technology Division

\title{
Caustic Leaching of SRS Tank 12H Sludge With and Without Chelating Agents
}

\author{
Barry B. Spencer \\ Jack L. Collins \\ Rodney D. Hunt
}

Date Published: April 2003

Prepared by the

OAK RIDGE NATIONAL LABORATORY

P.O. Box 2008

Oak Ridge, Tennessee 37831-6254

managed by

UT-Battelle, LLC

for the

U.S. DEPARTMENT OF ENERGY

under contract DE-AC05-00OR22725 


\section{CONTENTS}

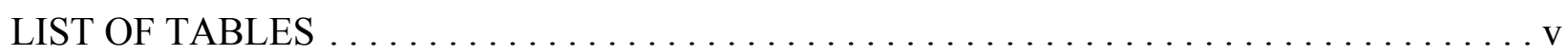

LIST OF FIGURES $\ldots \ldots \ldots \ldots \ldots \ldots \ldots \ldots \ldots \ldots \ldots \ldots \ldots \ldots \ldots$ vii

LIST OF ACRONYMS $\ldots \ldots \ldots \ldots \ldots \ldots \ldots \ldots \ldots \ldots \ldots \ldots \ldots \ldots \ldots \ldots \ldots$

EXECUTIVE SUMMARY $\ldots \ldots \ldots \ldots \ldots \ldots \ldots \ldots \ldots \ldots \ldots \ldots \ldots \ldots \ldots \ldots$

1. INTRODUCTION $\ldots \ldots \ldots \ldots \ldots \ldots \ldots \ldots \ldots \ldots \ldots \ldots \ldots \ldots \ldots \ldots$

1.1 FORMATION OF HIGH-LEVEL WASTE AND THE NEED TO

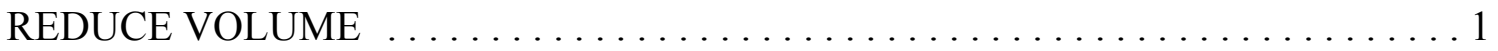

1.2 ENHANCED SLUDGE WASHING $\ldots \ldots \ldots \ldots \ldots \ldots \ldots \ldots \ldots \ldots \ldots \ldots \ldots \ldots \ldots$

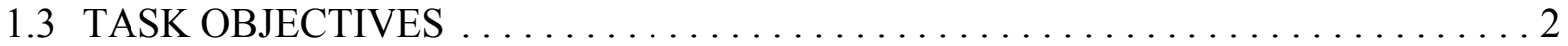

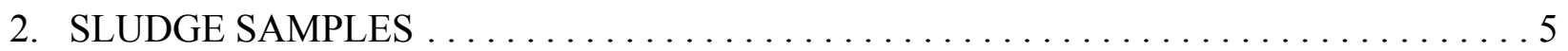

3. EXPERIMENTAL PROCEDURES $\ldots \ldots \ldots \ldots \ldots \ldots \ldots \ldots \ldots \ldots \ldots \ldots$

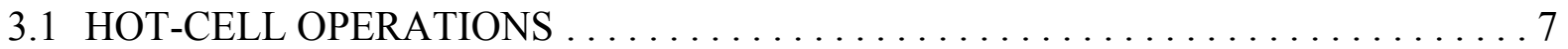

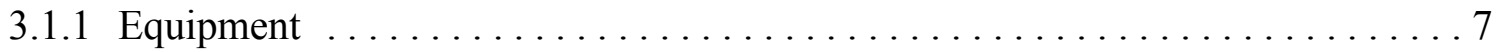

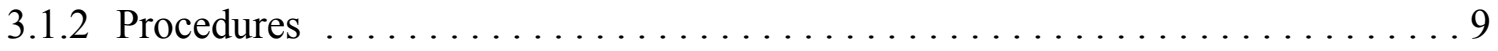

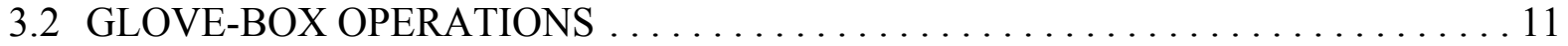

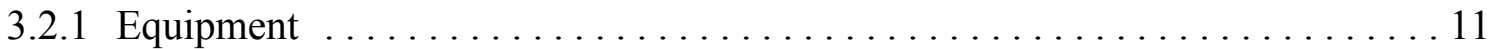

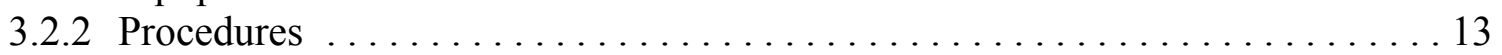

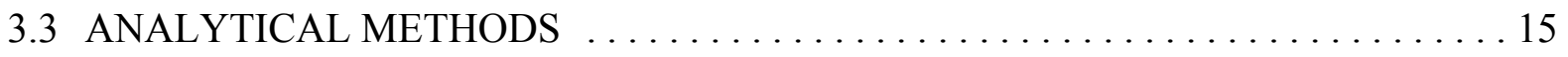

3.3.1 Preliminary Characterization of Sludge Samples $\ldots \ldots \ldots \ldots \ldots \ldots \ldots \ldots 15$

3.3.2 Analysis of Sludge and Leachates . . . . . . . . . . . . . . . 15

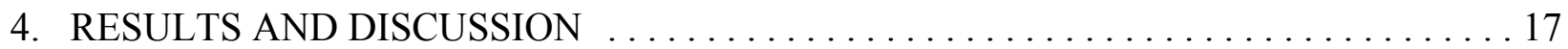

4.1 OBSERVATION AND CHARACTERIZATION OF SLUDGE SAMPLES $\ldots \ldots \ldots 17$

4.2 EFFECT OF WASHING SLUDGE $\ldots \ldots \ldots \ldots \ldots \ldots \ldots \ldots \ldots \ldots \ldots \ldots \ldots$

4.3 LEACHING WITH CAUSTIC AND CAUSTIC-CHELATING AGENTS . . . . . . 20

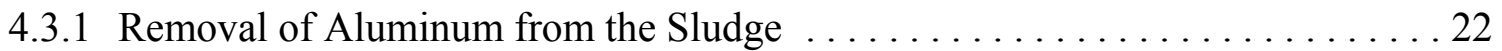

4.3.2 Dissolution of Other Metals . . . . . . . . . . . . . . . . . . . . . 29

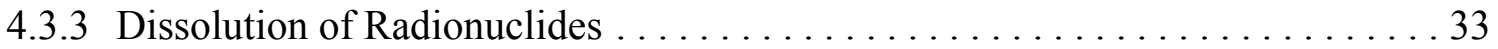

5. CONCLUSIONS AND RECOMMENDATIONS $\ldots \ldots \ldots \ldots \ldots \ldots \ldots \ldots \ldots \ldots$

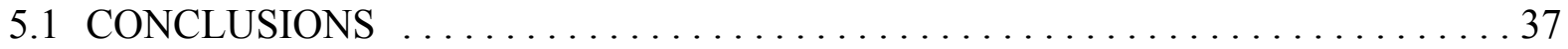

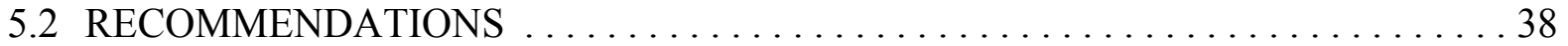

6. ACKNOWLEDGMENTS . . . . . . . . . . . . . . . . . . . . . 39

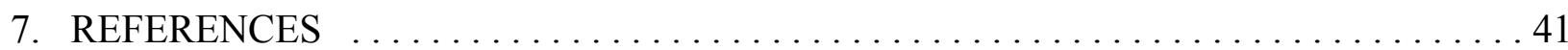




\section{LIST OF TABLES}

\section{Table}

\section{Page}

1.1 Suggested matrix of tests for the sludge washing project $\ldots \ldots \ldots \ldots \ldots \ldots \ldots \ldots$

2.1 SRS analysis of tank $12 \mathrm{H}$ sludge provided for the leaching tests $\ldots \ldots \ldots \ldots \ldots$

3.1 Description of dispensed sludge samples $\ldots \ldots \ldots \ldots \ldots \ldots \ldots \ldots \ldots \ldots \ldots \ldots \ldots$

4.1 Summary characterization of centrifuged wet sludge samples $\ldots \ldots \ldots \ldots \ldots \ldots$

4.2 Analysis of sludge and wash solution and calculated fraction of components

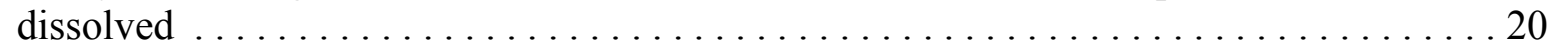

4.3 Comparison of SRS and ORNL analyses of tank $12 \mathrm{H}$ sludge for selected

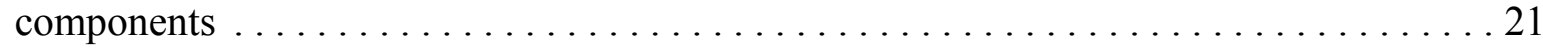

4.4 Actual sludge samples used and the actual conditions of the tests $\ldots \ldots \ldots \ldots \ldots 22$

4.5 Analysis of leachate solution: test at $3.0 \mathrm{~m} \mathrm{NaOH}, 80 \mathrm{EC}$, using sludge sample \#12 . . . 23

4.6 Analysis of leachate solution: test at $3.0 \mathrm{~m} \mathrm{NaOH}, 60 \mathrm{EC}$, using sludge sample \#11 . . . 24

4.7 Analysis of leachate solution: test at $3.0 \mathrm{~m} \mathrm{NaOH}-0.1 \mathrm{~m}$ TEA, 60EC,

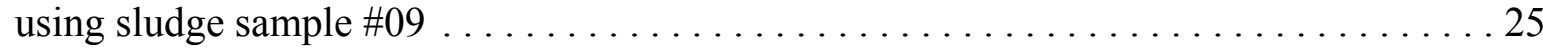

4.8 Analysis of leachate solution: test at $3.0 \mathrm{~m} \mathrm{NaOH}-3.0 \mathrm{~m}$ TEA, 60EC,

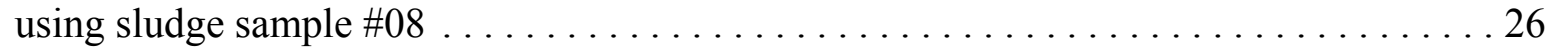

4.9 Analysis of leachate solution: test at $0.1 m \mathrm{NaOH}-2.9 m \mathrm{NaNO}_{3}, 60 \mathrm{EC}$,

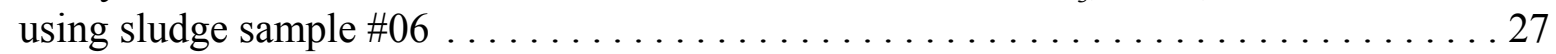

4.10 Analysis of leachate solution: test at $0.1 m \mathrm{NaOH}-2.9 m \mathrm{NaNO}_{3}-0.1 m$ TEA,

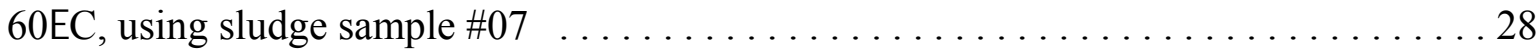




\section{LIST OF FIGURES}

Figure $\quad$ Page

ES.1 Leaching of aluminum in the six tests performed $\ldots \ldots \ldots \ldots \ldots \ldots \ldots$ xii

3.1 Installation of catch pan on in-cell platform as viewed through the cell window $\ldots \ldots 8$

3.2 The mixing vessel, vortex mixer, and electronic balance during installation $\ldots \ldots \ldots 8$

3.3 Dispensing the sludge into uniform volumes of slurry $\ldots \ldots \ldots \ldots \ldots \ldots \ldots \ldots$

3.4 Hot plate/stirrers with aluminum blocks and the high-temperature-limiting controller

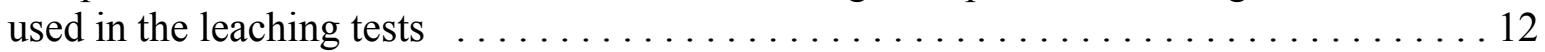

3.5 View of the glove box showing the experimental apparatus $\ldots \ldots \ldots \ldots \ldots$

4.1 Aluminum concentration in the leachates as a function of time $\ldots \ldots \ldots \ldots \ldots \ldots$

4.2 Photographs of leachates showing (a) the typical light-yellow color and (b) the green color produced by high TEA concentration $\ldots \ldots \ldots \ldots \ldots \ldots \ldots \ldots \ldots \ldots \ldots \ldots$

4.3 Leaching of nickel at the higher concentration of TEA $\ldots \ldots \ldots \ldots \ldots \ldots \ldots \ldots$

4.4 Iron concentration in the leachates, showing increases with addition of TEA . . . . . 32

4.5 Leaching of copper in $3.0 \mathrm{~m} \mathrm{NaOH}$, showing increases with addition of TEA . . . . . 33

4.6 Concentration of ${ }^{137} \mathrm{Cs}$ in leachates of all tests $\ldots \ldots \ldots \ldots \ldots \ldots \ldots \ldots \ldots \ldots$

4.7 Leaching of ${ }^{60} \mathrm{Co}$ at the higher concentrations of TEA $\ldots \ldots \ldots \ldots \ldots \ldots \ldots \ldots$

4.8 Minor leaching of ${ }^{154} \mathrm{Eu}$ from the sludge at the higher concentration of TEA . . . . . 36 


\section{LIST OF ACRONYMS}

CSD Chemical Sciences Division

DOE Department of Energy

ESP Extended Sludge Processing

ESW enhanced sludge washing

HLW high-level radioactive waste

HM heavy metal

ICP-AES inductively coupled plasma-atomic emission spectroscopy

LLW low-level radioactive waste

ORNL Oak Ridge National Laboratory

PPCO polypropylene copolymer

PTR platinum temperature resistance

PUREX plutonium-uranium extraction

$\mathrm{RCF}$ relative centrifugal force

SRS Savannah River Site

TEA triethanolamine

US United States 


\section{EXECUTIVE SUMMARY}

The primary objective of this study was to measure the effect of adding triethanolamine (TEA) to caustic leaching solutions to improve the solubility of aluminum in actual tank-waste sludge. High-level radioactive waste sludge that had a high aluminum assay was used for the tests. This waste, which originated with the processing of aluminum-clad/aluminum-alloy fuels, generates high levels of heat because of the high ${ }^{90} \mathrm{Sr}$ concentration and contains hard-to-dissolve boehmite phases. In concept, a chelating agent, such as TEA, can both improve the dissolution rate and increase the concentration in the liquid phase. For this reason, TEA could also increase the solubility of other sludge components that are potentially problematic to downstream processing. Tests were conducted to determine if this were the case. Because of its relatively high vapor pressure, process design should include methods to minimize losses of the TEA.

Sludge was retrieved from tank $12 \mathrm{H}$ at the Savannah River Site by on-site personnel, and then shipped to Oak Ridge National Laboratory for the study. The sludge contained a small quantity of rocky debris. One slate-like flat piece, which had approximate dimensions of $1 \frac{11 / 4}{4} 1 / 2 \times 1 / 8$ in., was recovered. Additional gravel-like fragments with approximate diameters ranging from $1 / 8$ to $1 / 4$ in. were also recovered by sieving the sludge slurry through a $1.4-\mathrm{mm}$ square-pitch stainless steel mesh. These particles ranged from a yellow quartz-like material to grey-colored gravel. Of the $32.50 \mathrm{~g}$ of sludge received, the mass of the debris was only $0.89 \mathrm{~g}$, and the finely divided sludge comprised $-97 \%$ of the mass. The sludge was successfully subdivided into uniform aliquots during hot-cell operations. Analytical measurements confirmed the uniformity of the samples. The smaller sludge samples were then used as needed for leaching experiments conducted in a glove box.

Six tests were performed with leachate concentrations ranging from 0.1 to $3.0 \mathrm{~m} \mathrm{NaOH}$, 0 to $3.0 \mathrm{~m}$ TEA and 0 to $2.9 \mathrm{~m} \mathrm{NaNO}_{3}$. Figure ES.1 illustrates the leaching of aluminum in all six tests. One test was performed at an operating temperature of $80 \mathrm{EC}$ to obtain baseline data, and the remaining five tests were all performed at $60 \mathrm{EC}$. A leaching solution of $3.0 \mathrm{~m} \mathrm{NaOH}$ was used for the test performed at $80 \mathrm{EC}$ and for one of the tests performed at $60 \mathrm{EC}$. These results indicated that more aluminum entered the solution at the higher temperature, though equilibrium was achieved at both temperatures within - 10 days. The addition of TEA significantly increased the concentration of aluminum in the leachate, and the concentration continued to increase even after 11 days of processing. The fraction of aluminum dissolved at $60 \mathrm{EC}$ increased from $-35 \%$ using $3.0 \mathrm{~m} \mathrm{NaOH}$ alone to $-87 \%$ using a combination of $3.0 \mathrm{~m} \mathrm{NaOH}$ and $3.0 \mathrm{~m}$ TEA. The high-nitrate, lowhydroxide solutions did not significantly dissolve the aluminum, because aluminate ion could not be produced. A small addition of TEA had no effect on this process.

The use of TEA also increased the solubility of some other sludge components. The fractions of copper, nickel, and iron that were dissolved increased to 72,13 , and $52 \%$, respectively. However, the original fractions of these metals were only $0.055,0.72$, and $3.1 \%$, respectively, of the dry mass of the sludge and therefore represent minor constituents. The presence of nickel in the leachate did have a dramatic effect on its color, which changed from light yellow to deep green as the nickel concentration increased. By comparison, the baseline leaching with $3.0 \mathrm{~m} \mathrm{NaOH}$ at $60 \mathrm{EC}$ removed $-14 \%$ of the copper; iron and nickel were below the detectable limit. 


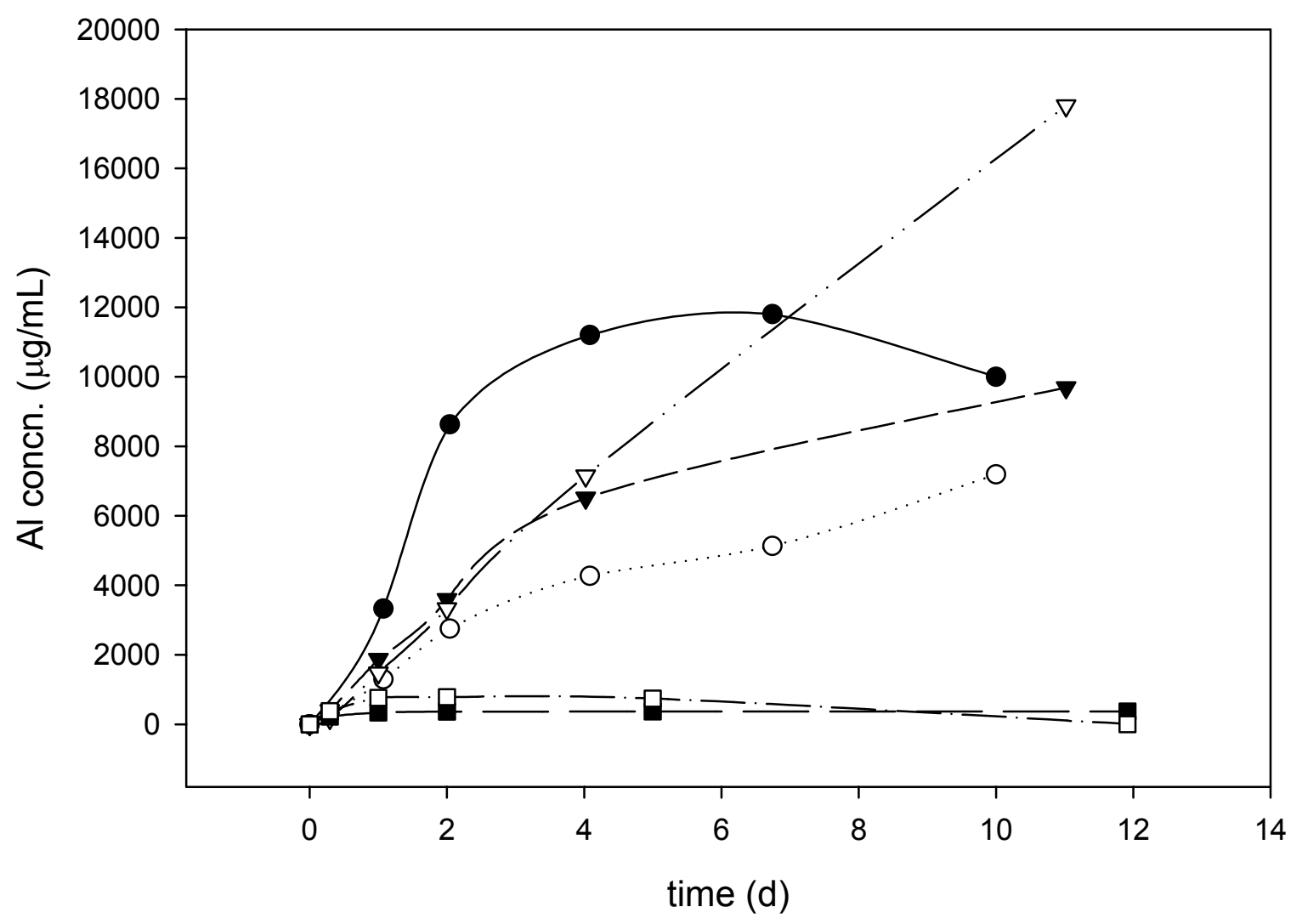

$$
\begin{aligned}
& \longrightarrow 3.0 \mathrm{~m} \mathrm{NaOH} @ 80^{\circ} \mathrm{C} \\
& 3.0 m \mathrm{NaOH} @ 60^{\circ} \mathrm{C} \\
& \rightarrow-3.0 \mathrm{~m} \mathrm{NaOH} \& 0.1 \mathrm{~m} \text { TEA } @ 60^{\circ} \mathrm{C} \\
& \rightarrow \cdots 3.0 \mathrm{~m} \mathrm{NaOH} \& 3.0 \mathrm{~m} \text { TEA } @ 60^{\circ} \mathrm{C} \\
& \longrightarrow 0.1 \mathrm{~m} \mathrm{NaOH} \& 2.9 \mathrm{~m} \mathrm{NaNO}_{3} @ 60^{\circ} \mathrm{C} \\
& \rightarrow 0.1 m \mathrm{NaOH} \& 2.9 m \mathrm{NaNO}_{3} \& 0.1 \mathrm{~m} \text { TEA @60 } 60^{\circ} \mathrm{C}
\end{aligned}
$$

Fig. ES.1. Leaching of aluminum in the six tests performed.

The TEA also had a measurable effect on the solubility of the radionuclides ${ }^{137} \mathrm{Cs},{ }^{60} \mathrm{Co}$, and ${ }^{154} \mathrm{Eu}$. The presence of ${ }^{137} \mathrm{Cs}$ in the leachates was expected because of the ${ }^{137} \mathrm{Cs}$-bearing wash solution retained by the wet washed sludge and because of its high solubility in aqueous media. The high-nitrate leaches, which were the least effective of the leaching solutions, removed $69 \%$ of the ${ }^{137} \mathrm{Cs}$ from the washed sludge, while a combination of $3.0 \mathrm{~m} \mathrm{NaOH}$ and $3.0 \mathrm{~m}$ TEA removed $96 \%$. Very little ${ }^{60} \mathrm{Co}$ was removed from the sludge except with the use of the $3.0 \mathrm{~m} \mathrm{NaOH}-3.0 \mathrm{~m}$ TEA solution, which removed 53\%. This solution was also the only one that dissolved europium; however, only $0.4 \%$ of the ${ }^{154} \mathrm{Eu}$ was removed from the sludge. 


\section{INTRODUCTION}

\subsection{FORMATION OF HIGH-LEVEL WASTE AND THE NEED TO REDUCE VOLUME}

By the end of 1995, the chemical reprocessing of spent reactor fuel and irradiated targets had produced 215,300,000 L of solid high-level waste (HLW) and 158,100,000 L of liquid HLW (U.S. Department of Energy, 1996). Reprocessing of spent fuel produces an acidic liquid waste. At Hanford and the Savannah River Site (SRS), this liquid HLW was transferred to underground storage tanks and neutralized with sodium hydroxide to prevent corrosion of the carbon-steel tanks. The neutralization of the HLW formed hydrated oxides, which precipitated and created a layer of sludge. If the neutralized supernatant liquids were concentrated sufficiently by evaporation, sodium nitrite and sodium nitrate crystallized to form salt cakes. The radioactivity of HLW results primarily from ${ }^{137} \mathrm{Cs}$ in the liquids/supernatants and ${ }^{90} \mathrm{Sr}$ in the solids/sludges. Most of the relatively small amount of transuranics can be found in the solids.

The U.S. Department of Energy (DOE) is required to treat and safely dispose of this HLW. It is expected that separation technologies will be used to divide the tank waste into HLW and lowlevel waste (LLW). After these separation or pretreatment steps are completed, the segregated waste will be immobilized and geologically isolated. After the HLW has been concentrated at Hanford and the SRS, it will be incorporated into borosilicate glass, which will be sent to a geological repository for permanent disposal. The LLW will be immobilized in grout or glass and stored onsite. To illustrate the quantities of waste involved, it has been estimated that pretreatment will generate 78,700,000 kg of LLW and 4,300,000 kg of HLW at Hanford alone (DeMuth, 1996).

Technology development efforts have focused on reducing the volume of the HLW because of the high costs associated with processing, immobilizing, and disposing of it. HLW costs are \$2126 per kilogram of waste oxide, while those for LLW are \$64 (DeMuth, 1996). The primary incentives to reduce the total volume of HLW glass include a lower overall life-cycle cost and the limited availability of repository space.

\subsection{ENHANCED SLUDGE WASHING}

HLW volume can be reduced by separating the more abundant inert constituents, such as sodium and aluminum, from the radionuclides in the sludges. This process would also remove minor components such as chromium, sulfate, and phosphate, which can cause vitrification problems. Hunt et al. (1998) summarize the primary treatment options; simple sludge washing, enhanced sludge washing (ESW), and advanced separations. Simple sludge washing uses only water or inhibited water, which contains $0.01 \mathrm{M}$ sodium nitrite and $0.01 \mathrm{M}$ sodium hydroxide. ESW refers to simple sludge washing that is followed by caustic leaching with 2-3 $M$ sodium hydroxide at an elevated temperature. The leached solids are then washed with the inhibited water to remove the dissolved components and any residual sodium hydroxide. At the SRS, the ESW process is called Extended Sludge Processing (ESP). Advanced separations consist of complete dissolution, if possible, followed by extensive radionuclide separation. ESW, or ESP, was selected as the baseline process to treat the Hanford sludges and high-aluminum sludges. 
The ESW process is expected to solubilize the aluminum in the sludge by converting different forms of aluminum oxides to soluble sodium aluminate (Lumetta et al., 1996).

$$
\begin{array}{ll}
\text { Boehmite } & \mathrm{AlOOH}(\mathrm{s})+\mathrm{OH}^{-}(\mathrm{aq})+\mathrm{H}_{2} \mathrm{O} \rightarrow \mathrm{Al}(\mathrm{OH})_{4}^{-}(\mathrm{aq}) \\
\text { Gibbsite } & \mathrm{Al}(\mathrm{OH})_{3}(\mathrm{~s})+\mathrm{OH}^{-}(\mathrm{aq}) \rightarrow \mathrm{Al}(\mathrm{OH})_{4}^{-}(\mathrm{aq})
\end{array}
$$

A chelating agent, if added to the leaching solution, binds the aluminate ion, thereby removing it from the preceeding equilibria, permitting additional gibbsite or boehmite to dissolve.

In-tank processing may be performed, with the primary obstacle that the entire contents of the tank must be heated. Out-of-tank processes are cumbersome because the rate of dissolution is slow, requiring 10 to 50 days to achieve equilibrium (depending on the temperature and nitrate concentration). It has been proposed that chelating agents could lower the temperature required to achieve the desired dissolution and/or increase the dissolution rate (Palmer 2001). Tests with bayerite, boehmite, and gibbsite indicate that triethanolamine (TEA) is a good candidate for this role. However, its relatively high vapor pressure must be considered in process design to minimize losses. General loss-control methods include sealed and/or pressurized systems (which are inappropriate for in-tank processing) or capture and recycle systems (which involve added process steps).

\subsection{TASK OBJECTIVES}

A quantity of sludge with a high aluminum content was obtained from tank $12 \mathrm{H}$ at the SRS. This sludge was subdivided into several small uniform samples to provide stock material for experiments designed to evaluate the effect of adding a chelating agent to the ESW process.

In previous studies, TEA proved to be the best of the chelating agents (Palmer, 2001). Six tests were planned with the sludge samples to determine the effectiveness of TEA in enhancing the solubility of the aluminum-containing phases in the sludge. Based upon guidance from the Chemical Sciences Division (CSD) at Oak Ridge National Laboratory (ORNL), the test matrix shown in Table 1.1 was developed. The sludge:leachate ratios in the table are the lowest suggested; a greater sludge concentration was considered desirable. A baseline test was conducted in which a sludge sample was heated at $80^{\circ} \mathrm{C}$ with $3 \mathrm{~m} \mathrm{NaOH}$ for $\$ 7$ days to establish equilibrium. All other tests were performed at $60 \mathrm{EC}$, including (1) a repeat of the baseline, except at the lower temperature; (2) two tests with $3.0 \mathrm{~m}$ caustic solutions, one using a concentration of $3.0 \mathrm{~m}$ TEA and one using a concentration of $0.1 \mathrm{~m}$ TEA; and (3) two tests with $0.1 \mathrm{~m} \mathrm{NaOH}$ plus $2.9 m \mathrm{NaNO}_{3}$, one using a concentration of $0.1 \mathrm{~m}$ TEA and one without TEA. The latter tests with high nitrate and low caustic provide an environment with total ionic strength comparable to that of the caustic solutions but without a hydroxide ion to react as in Eqs. (1.1) and (1.2). 
Table 1.1 Suggested matrix of tests for the sludge washing project

\begin{tabular}{cccccc}
\hline & & & \multicolumn{3}{c}{ Concn. in leaching solution $(m)$} \\
\cline { 3 - 6 } Test & Temp. (EC) & Sludge:Leaching solution $(\mathrm{g} / \mathrm{g})^{a}$ & $\mathrm{NaOH}$ & $\mathrm{TEA}^{b}$ & $\mathrm{NaNO}_{3}$ \\
\hline $1^{c}$ & 80 & $1: 20$ & 3.0 & 0 & 0 \\
2 & 60 & $1: 20$ & 3.0 & 0 & 0 \\
3 & 60 & $1: 20$ & 3.0 & 0.1 & 0 \\
4 & 60 & $1: 20$ & 3.0 & 3.0 & 0 \\
5 & 60 & $1: 20$ & 0.1 & 0 & 2.9 \\
6 & 60 & $1: 20$ & 0.1 & 0.1 & 2.9 \\
\hline
\end{tabular}

${ }^{a}$ Minimum value; a higher sludge:leachate ratio is desirable.

${ }^{b}$ Triethanolamine.

${ }^{c}$ Baseline condition.

The primary metric was the fraction of aluminum removed from the sludge. For tests performed at a fixed ratio of solid to liquid, this value is directly reflected in the concentration of aluminum in the wash solution. Success of the process was dependent on the segregation of the aluminum from the long-lived actinides. Measurements of the alpha activity in the leach solution provided insight into the degree of separation. 



\section{SLUDGE SAMPLES}

Sludge samples were obtained from tank $12 \mathrm{H}$ at SRS for use in conducting experiments to determine the effectiveness of TEA in enhancing the solubility of the aluminum-containing phases in the sludge. Based upon inductively coupled plasma-atomic emission spectroscopy (ICP-AES) analysis at SRS, the concentration of aluminum in the wet sludge was determined to be about $31 \mathrm{wt} \%$. The water content of a sludge sample was recently determined by Fondeur's team (2001) at SRS. A sample weighing $0.6 \mathrm{~g}$ was heated to $150^{\circ} \mathrm{C}$ for $\sim 2 \mathrm{~h}$. Weight measurements indicated that the water content was $9 \mathrm{wt} \%$. This represents both free water and water of hydration. Based upon this value and the analyses of the radioactive components, only $7.7 \mathrm{~g}$ of the sludge could be shipped in each Type A container. A total of four shipments were made in Type A containers to provide a total of about $31 \mathrm{~g}$ of sludge. The ORNL shipping department provided two empty Type A containers to SRS. Table 2.1 lists the activity of the radionuclides and the weight percentages of the nonradioactive cations per gram of sludge as determined by the SRS analysis. The sodium concentration was not given.

Table 2.1. SRS analysis of tank $12 \mathrm{H}$ sludge provided for the leaching tests ${ }^{a}$

\begin{tabular}{ll}
\hline \multicolumn{1}{c}{ Component } & Amount/g \\
\cline { 2 - 2 } Process metals & $0.304 \mathrm{~g}$ \\
$\mathrm{Al}$ & $0.0005 \mathrm{~g}$ \\
$\mathrm{Ba}$ & $0.038 \mathrm{~g}$ \\
$\mathrm{Fe}$ & $0.008 \mathrm{~g}$ \\
$\mathrm{Hg}$ & $0.002 \mathrm{~g}$ \\
$\mathrm{~K}$ & $0.002 \mathrm{~g}$ \\
$\mathrm{Mg}$ & $0.018 \mathrm{~g}$ \\
$\mathrm{Mn}$ & $0.005 \mathrm{~g}$ \\
$\mathrm{Ni}$ & \\
$\mathrm{Radionuclides}$ & $0.0014 \mathrm{mCi}$ \\
$\mathrm{Co}-60$ & $14.9 \mathrm{mCi}$ \\
$\mathrm{Sr}-90$ & $0.081 \mathrm{mCi}$ \\
$\mathrm{Cs}-137$ & $0.0623 \mathrm{mCi}$ \\
Eu-154 & $0.0094 \mathrm{mCi}$ \\
Eu-155 & $3.3 \mathrm{mg}$ \\
$\mathrm{U}-\mathrm{all}$ & $0.61 \mathrm{mCi}$ \\
$\mathrm{Pu}-238$ & $0.012 \mathrm{mCi}$ \\
$\mathrm{Pu}-239$ & $0.845 \mathrm{mCi}$ \\
$\mathrm{Pu}-241$ & $0.031 \mathrm{mCi}$ \\
$\mathrm{Am}-241$ &
\end{tabular}

${ }^{a}$ Fondeur, 2001. 



\section{EXPERIMENTAL PROCEDURES}

The overall strategy for performing the leaching tests was to handle the as-received sludge in Hot Cell A of Building 4501 at ORNL, blend the material into a uniform slurry, and subdivide it into small aliquots of 1 to $2 \mathrm{~g}$ for leaching experiments in a glove box located in the 4501 Alpha Facility. Because the total mass of received sludge produced a high radiation field and because the operations to wash, blend, and aliquot the sludge could use relatively simple equipment, hot-cell handling of the sludge was a logical approach. The washing step reduced the activity of the sample by removing soluble ${ }^{137} \mathrm{Cs}$. Once washed and subdivided, the smaller samples could be handled in a glove box, where light shielding would protect the experimentalist while providing better access (dexterity) for handling small laboratory equipment.

Before the experiments began, the hot cell and the glove box were cleaned to minimize the potential for cross-contamination. The contamination level in the cell was low enough to permit cell entry. Most of the equipment in the hot cell was placed in a large stainless steel tray to contain spills. Whenever possible, the controls for the equipment were positioned outside of the hot cell and glove box.

\subsection{HOT-CELL OPERATIONS}

\subsubsection{Equipment}

Support platforms made from clean materials were fabricated and installed in Cell A to provide working surfaces. A stainless steel tray was placed on the higher platform to contain any potential spills during handling of the sludge. Figure 3.1 shows the tray being secured to the platform with large C-clamps. A shorter platform was used to support the tabletop centrifuge, which is shown with the lid open on the far-left side of Fig. 3.1. Because the cell was sufficiently clean to permit entry by personnel, the equipment was installed by a hands-on effort before the sludge was transferred to the cell.

A mixing vessel was fabricated from 304 stainless steel schedule 40 pipe components, specifically a $3 \times 4$-in. concentric reducer and a 3 -in. pipe cap. The bottom of the vessel was bored through and fitted with a $1 / 4-i n$. Swagelok ${ }^{\mathrm{TM}}$ ball valve. The components were joined by welding. The connecting tube and dispensing tube were kept short to minimize holdup of sludge in dead zones. A Plexiglas cover was fabricated to fit over the vessel. An electrically driven mixer with mechanical speed adjustment was mounted with the mixing vessel on a heavy laboratory stand, as illustrated in Fig. 3.2.

Prior to installation in the hot cell, the mixer was tested on an available plutonium-uranium extraction/heavy metal (PUREX/HM) sludge surrogate. The mixer speed was adjusted until the slurry appeared well mixed, but this process was conducted well under the speed that caused splatter. To verify operation, the surrogate was dispensed into 30-mL centrifuge tubes (which had been marked to indicate the 20 -mL level), centrifuged, and decanted. Weighing the samples before centrifugation and after decanting revealed that consistent samples could be produced. Additional methods of verification were used when the real sludge was processed (see Sect. 4.1). 


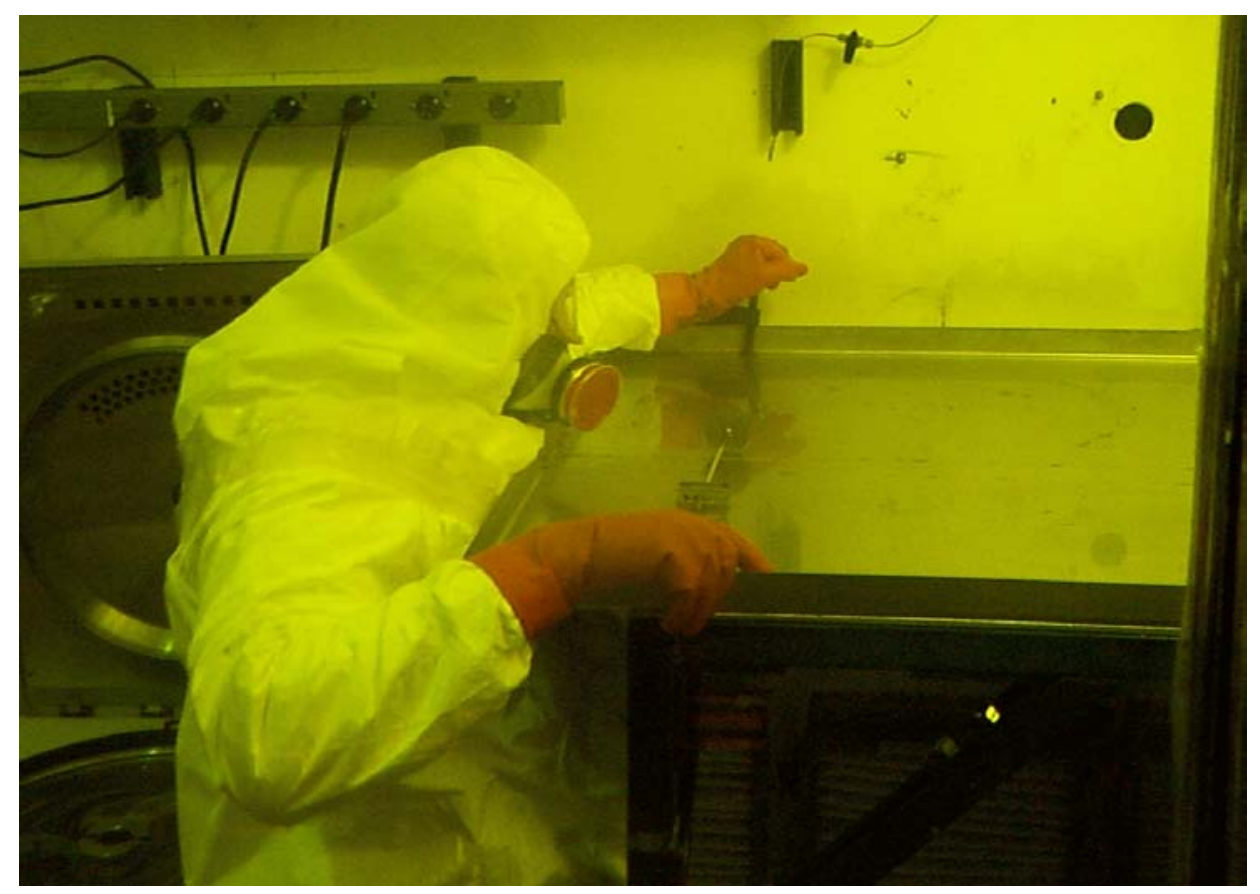

Fig. 3.1. Installation of catch pan on in-cell platform as viewed through the cell window.

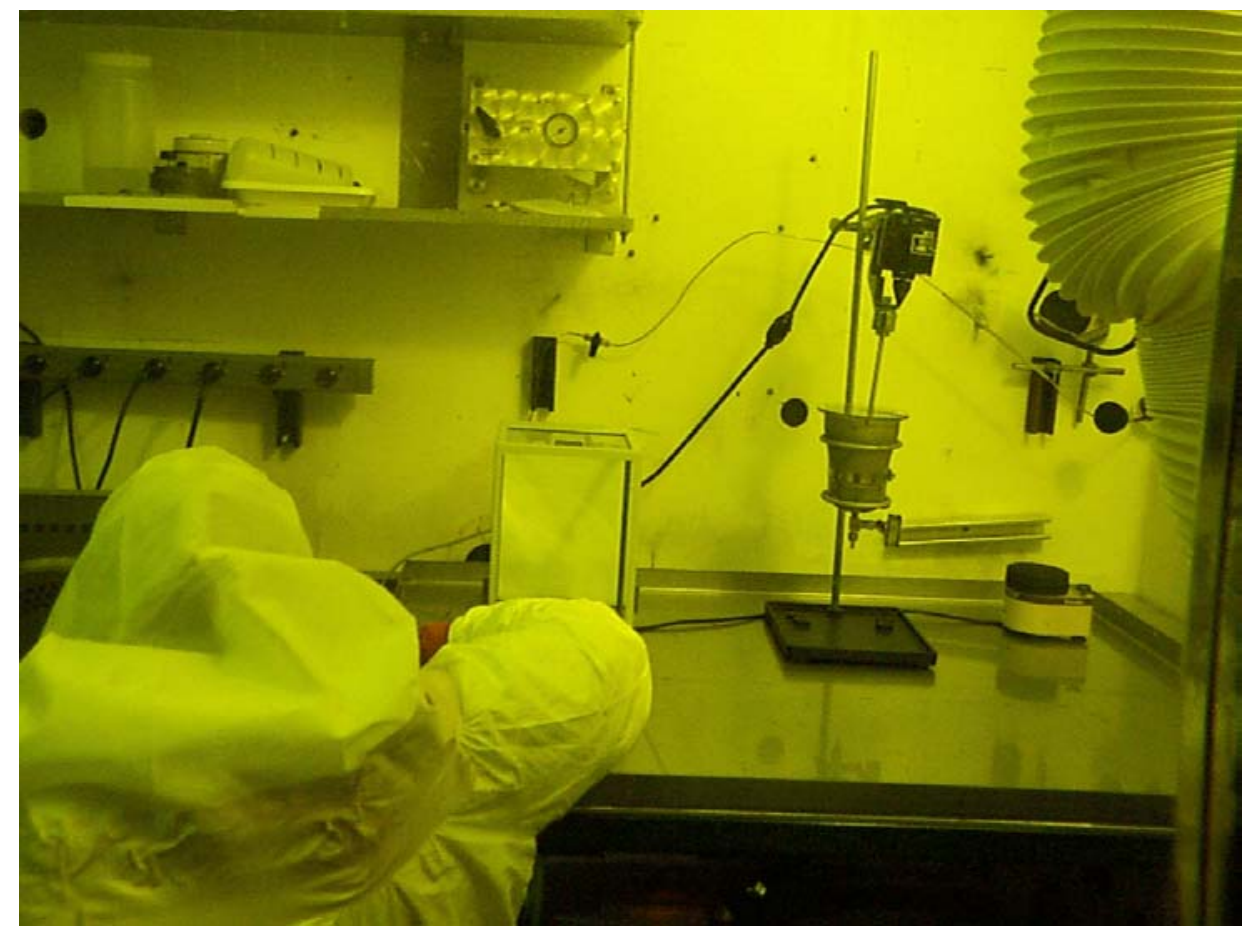

Fig. 3.2. The mixing vessel, vortex mixer, and electronic balance during installation. 
A calibrated Mettler PM4000 top-loading balance, which has a capacity of $4000 \mathrm{~g}$ and a precision of $0.01 \mathrm{~g}$, was used in the hot cell to weigh the shipping bottles, sludge samples, inhibited water, and centrifuge bottles. A Thermolyne Maxi-mix II ${ }^{\mathrm{TM}}$ vortex mixer was used to suspend the sludge samples. An International Equipment Company Centra-GP8 tabletop centrifuge was used to separate the liquid from the solids. The centrifuge was equipped with a four-place swingingbucket rotor (\#269). One pair of opposing buckets was fitted with adapters for 250-mL centrifuge bottles, and the other pair was fitted with holders for $50-\mathrm{mL}$ centrifuge bottles. Because the sludge was dispensed into 30-mL centrifuge bottles, a thick plastic liner was used to adapt the slots for the $50-\mathrm{mL}$ bottles to the smaller-size bottles. The centrifuge bottles were made of Nalgene ${ }^{\mathrm{TM}}$ polypropylene.

A variety of other small implements were designed and fabricated to aid operations: (1) plastic bottle holders for both the 250- and 30-mL centrifuge bottles, (2) a wooden holder for a 1-L polypropylene bottle, (3) a bottle-handling tool, (4) a tool to prevent the centrifuge rotor from turning while the lid clamp was being tightened, and (5) a rubber-tipped push-rod tool for operating the electronic equipment.

\subsubsection{Procedures}

The sludge was received from SRS in four portions, which were packaged separately. Inside each shipping package was a lead "pig," which contained a stainless steel container with screw-top lid and what appeared to be a neoprene seal. The sludge was inside the stainless steel container. The knurled container lid was removed without difficulty using the in-cell manipulators. Nearly all of the sample was transferred from the container directly into a preweighed $250-\mathrm{mL}$ wide-mouthed centrifuge bottle. The sludge was dark brown in color, powdery, and appeared very dry. No visible quantity of sludge remained in the stainless steel container. Both the container and the bottle were weighed with the in-cell balance. Then $-25 \mathrm{~mL}$ of inhibited water, which consisted of $0.01 \mathrm{M}$ sodium hydroxide and $0.01 \mathrm{M}$ sodium nitrite, was added to the stainless steel container and the cap was replaced. After vigorous shaking, the container was reopened, and the liquid, which might contain sludge, was poured into the $250-\mathrm{mL}$ centrifuge bottle. This rinse step was repeated for each shipping container so that all the sludge was accumulated into the one centrifuge bottle. Drying and reweighing of the stainless steel shipping containers revealed that very small additional quantities of sludge were recovered by rinsing the containers. The largest amount of waste that was transferred during a rinse step was $0.03 \mathrm{~g}$. Therefore, nearly all of the sludge was transferred while in the dry state. The total amount of as-received sludge was $32.50 \mathrm{~g}$. The centrifuge bottle with the sludge was sealed and allowed to sit for 11 days at room temperature (-23EC) before additional processing was performed.

To complete an initial washing of the sludge, inhibited water was added to the sludge in the centrifuge bottle in sufficient quantity to result in a 5:1 mass ratio of wash solution to as-received sludge. The mixture was agitated on the vortex mixer and allowed to sit overnight at room temperature. It was then centrifuged for $20 \mathrm{~min}$ at $2000 \mathrm{rpm}$, which produced a relative centrifugal force (RCF) of $850 \mathrm{~g}$ (where $g$ represents a force equivalent to terrestrial gravity). The liquid was decanted to separate it from the settled solids, and the liquid was saved.

A sufficient quantity of inhibited water was added to the sludge to produce a slurry containing $-1.5 \mathrm{~g}$ of sludge per $20-\mathrm{mL}$ mixture. That amount of inhibited water was used in 
aliquots. First it was added to the $250-\mathrm{mL}$ centrifuge bottle containing the sludge, and the vortex mixer was used to suspend the sludge before the slurry was transferred to the stainless steel mixing vessel. Several such rinses were used to ensure complete transfer of the sludge to the mixing vessel. When the transfer was completed, the centrifuge bottle was dried and weighed to verify that the empty tare weight had been restored, thus indicating that all of the sludge was transferred to the mixing vessel.

While mixing the sludge in preparation for dispensing the sample aliquots, the mixer motor stalled. In addition, the dispensing valve plugged while attempting to dispense a test aliquot. Inspection revealed large solid particles in the sludge that had not been observed during the previous transfer processes. The sludge was temporarily stored in two $250-\mathrm{mL}$ centrifuge bottles, and the larger particles were retrieved from the mixing vessel using long forceps. When the sludge was returned to the mixing vessel, the sludge slurry was poured through a stainless steel wire mesh (square pitch with 1.4-mm free space between wires) to remove the large particles. Additional inhibited water was used to rinse the centrifuge bottles and solid particles to recover as much of the fine sludge as practical. The retrieved solid particles included one slate-like piece having approximate dimensions of $1 \frac{1}{4} \times 1 / 2 \times 1 / 8$ in. Smaller gravel-like fragments with approximate diameters ranging from $1 / 8$ to $1 / 4$ in. were also recovered. These solids ranged from a yellow quartzlike material to grey-colored gravel. Probing with a stainless steel rod revealed all these materials to be hard, and the larger slate-like piece was broken into two nearly equal pieces when supported at each end and pressed in the middle. All the large recovered particles were dried at room temperature and weighed; the total mass was $0.89 \mathrm{~g}$. The remaining fine sludge weighed $31.61 \mathrm{~g}$.

Mixing of the sludge then proceeded as expected. Sludge was dispensed into prenumbered $30-\mathrm{mL}$ centrifuge bottles to produce two sizes of samples. When the slurry in the mixing vessel was depleted, the inside surfaces and mixer shaft/propeller were rinsed with inhibited water, and the solid-liquid mixture was transferred to additional bottles. Table 3.1 describes the samples produced. Figure 3.3 shows the samples as they were prepared in the hot cell.

Table 3.1. Description of dispensed sludge samples

\begin{tabular}{lcl}
\hline Sample ID & Target dry sludge mass $(\mathbf{g})^{a}$ & \multicolumn{1}{c}{ Remarks } \\
\hline$\# 01-\# 10$ & 1.5 & Filled each bottle to the 20 -mL mark \\
$\# 11-\# 16$ & 2.0 & Filled each bottle to the neck, $-25-\mathrm{mL}$ \\
$\# 17-\# 18$ & 1.5 & Filled each bottle to the $20-\mathrm{mL}$ mark \\
$\# 19-\# 21$ & $\mathrm{n} / \mathrm{a}^{b}$ & Filled each bottle to the $20-\mathrm{mL}$ mark \\
\hline
\end{tabular}

${ }^{a}$ As used here, "dry" refers to the as-received sludge, which had no free water.

${ }^{b}$ Not applicable, a target could not be achieved because this material is from rinsedown. 


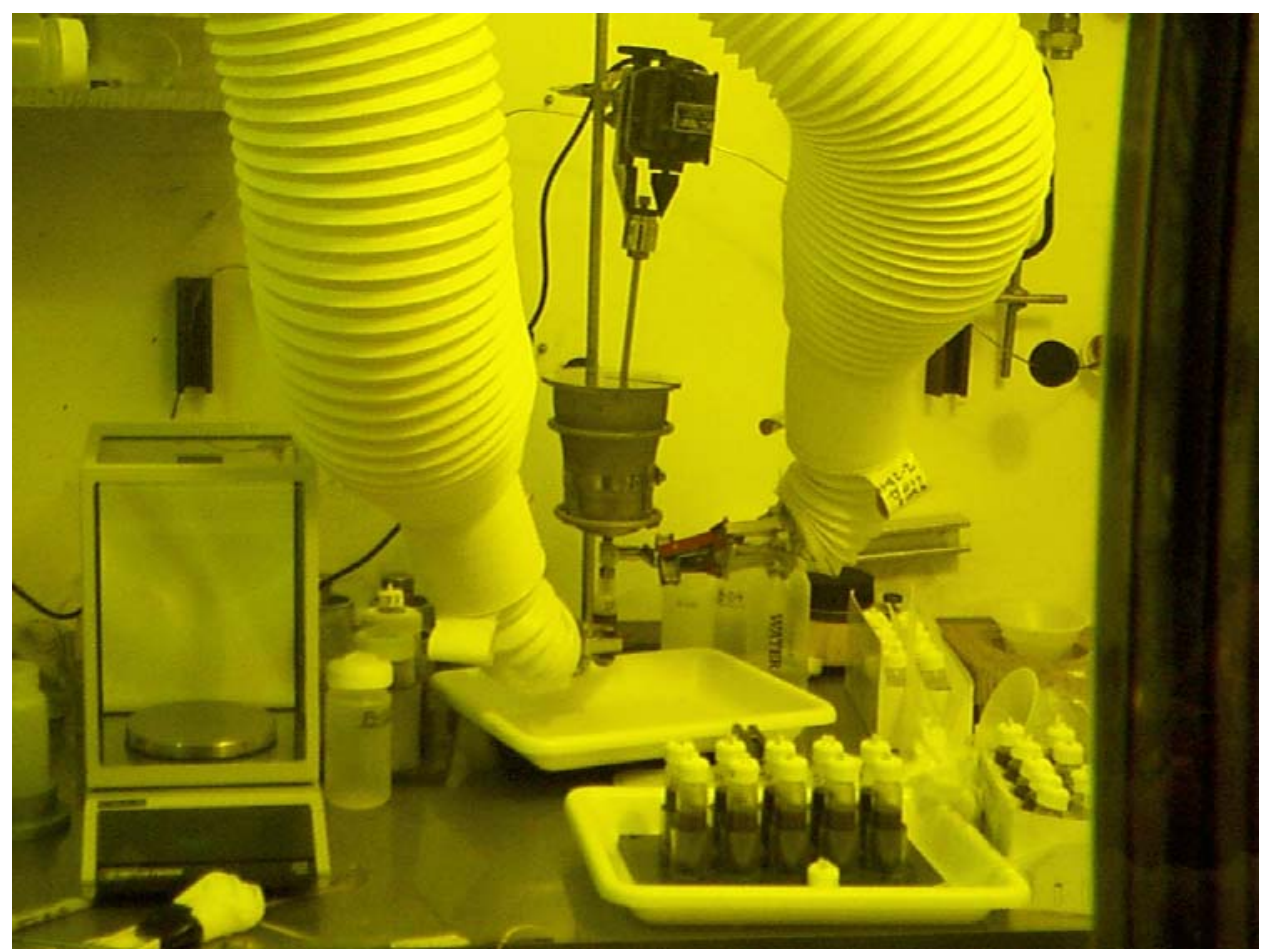

Fig. 3.3. Dispensing the sludge into uniform volumes of slurry.

The samples were allowed to sit overnight before continuing to the centrifugation step. The solids were noted to have settled somewhat; a clear liquid solution occupied about $40 \%$ of the sample volume. The samples were centrifuged for $20 \mathrm{~min}$ at $3000 \mathrm{rpm}$, which produced an RCF of $3600 \mathrm{~g}$, and the clear supernatant was decanted. The samples were weighed before and after decanting to obtain data on the ratio of supernatant to wet sludge. The decanted liquid was added to the previously saved wash solution to produce a composite wash solution having a mass of $518.67 \mathrm{~g}$.

The samples were removed from the cell and placed in a storage vault. The equipment needed to continue the experiment was removed from the hot cell and reinstalled in the glove box.

\subsection{GLOVE-BOX OPERATIONS}

\subsubsection{Equipment}

Two new systems were designed and built to leach the sludge samples. Figure 3.4 shows the two units on the bench top before they were moved to the glove box located in the Building 4501 Alpha Facility. Each unit consists of a Jenway Model 1103 hot plate/stirrer equipped with an external platinum temperature resistance (PTR) sensor. These hot plate/stirrers have built-in electronics to control both the sample temperature (from 0 to 200EC) and the stirring speed (from 0 to $1200 \mathrm{rpm})$. The sample holder for the hot plate/stirrer was made from a 
$8.625 \times 8.625 \times 3.063$-in. $(21.9 \times 21.9 \times 7.8$-cm $)$ aluminum block. Screws were used to attach small aluminum tabs to the block to hold it centered on the hot plate. Two holes were drilled into the aluminum block to serve as sample holders. One hole made in the center of the block, which has a diameter of 1.255 in. $(3.188 \mathrm{~cm})$ to accept a liner made from a section of 304 stainless steel tubing (BWG gage 11 with OD of 1.250 in. and ID of 1.010 in.), was the primary sample holder. A stainless steel liner was used so that the sample could be recovered if a centrifuge tube failed. An auxiliary hole in-line with a diagonal line across the block has a diameter of $1.010 \mathrm{in}$. Both of these locations were designed to accept the sludge samples as contained in the $30-\mathrm{mL}$ centrifuge bottles. Two holes were also drilled into the aluminum block adjacent to, and between, the sample holes to accept temperature sensors. One of these holes has a diameter of $0.106 \mathrm{in}$. to accept the PTR, and the other has a diameter of 0.042 in. to accept a thermocouple.
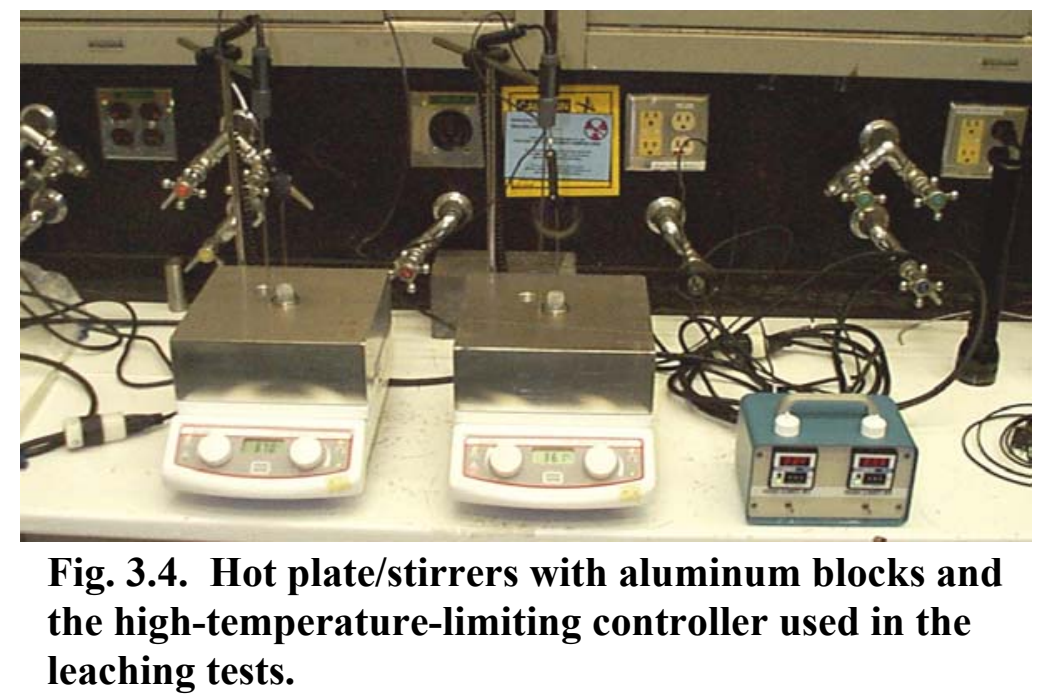

The massive aluminum blocks perform two functions. Their high thermal conductivity maintains a uniform temperature around the sample, while the nearly $4 \mathrm{in}$. of aluminum between the sample and the operator completely shields the beta radiation and significantly attenuates the gamma radiation emanating from the sample.

Each thermocouple was monitored with an OMEGA high-temperature controller with temperature indicator (Model CN-375, operating range 0 to 399EC). The apparatus cuts the power when the block temperature exceeds a specified value. Type-J thermocouples were used in this application. Both sets of apparatus were set up on the bench top and tested. Temperature readings from the thermocouple on the temperature-limiting controller and from the PTR probes used by the hot plate temperature controller, were calibrated with respect to a mercury thermometer using water as a working fluid.

The calibrated Mettler PM4000 top-loading balance used in the hot cell was recovered for use in the glove box. As previously mentioned, it has a capacity of $4000 \mathrm{~g}$ and a precision of $0.01 \mathrm{~g}$. It was used in the glove box to weigh the sludge sample, the leaching solutions, the stir bars, and both the tare and gross mass of the leachate sample bottles. 
A Thermolyne Maxi-mix $\mathrm{II}^{\mathrm{TM}}$ vortex mixer was used to mix the sludge samples with the leaching solutions. It was also used periodically throughout the leaching tests to ensure that the sludge samples were well mixed.

The major components were installed in the glove box, as shown in Fig. 3.5. The cylinders with the central hole shown between the hot plates are tungsten "inserts." These were used as shielding for the sludge samples whenever the samples were removed from the aluminum blocks.

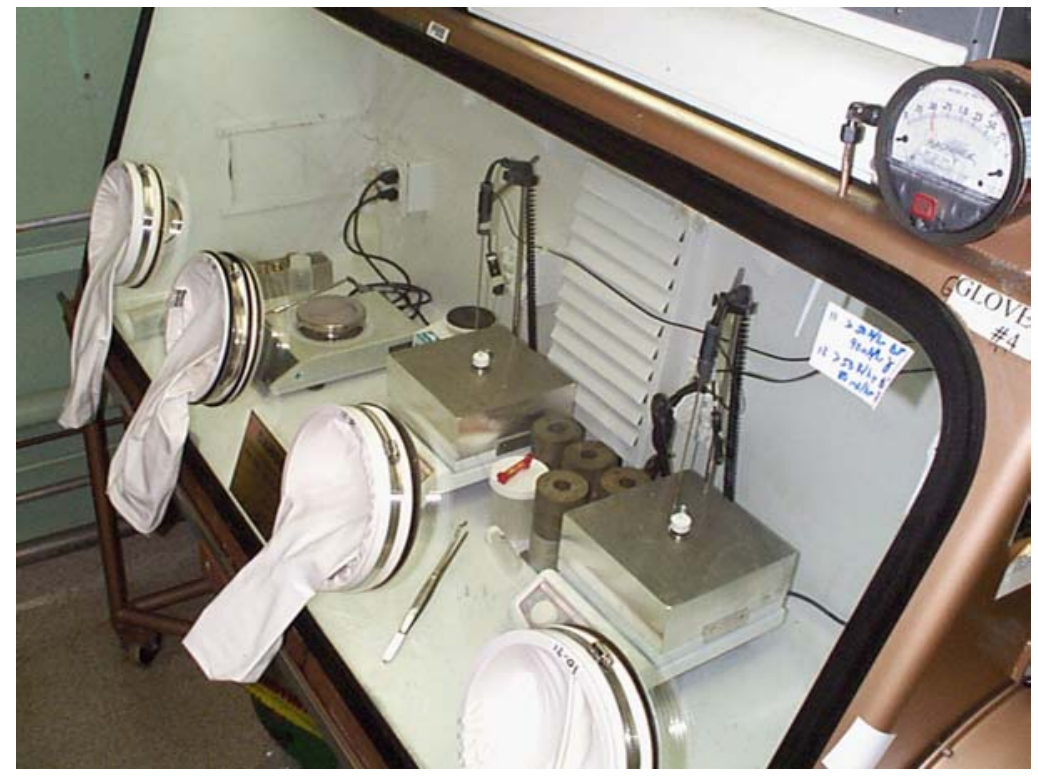

Fig. 3.5. View of the glove box showing the experimental apparatus.

Additional small-equipment items included long-handled tweezers/forceps for handling bottles, lead foil to provide hand shielding from beta radiation, plastic labware to store small items, syringes, and syringe filters.

\subsubsection{Procedures}

Leaching solutions were prepared in a clean lab and transferred to the glove box in plastic bottles. Solutions were prepared by weight using one of two balances: a calibrated Mettler PR8002 balance, which has a capacity of $8000 \mathrm{~g}$ and a precision of $0.01 \mathrm{~g}$, or a calibrated Mettler AE163, which has a capacity of $160 \mathrm{~g}$ and a precision of $0.0001 \mathrm{~g}$. The amount of water in the sludge samples was estimated from data obtained during the hot-cell portion of the work. The quantity of reagents prepared was adjusted so that both the desired solids:liquid ratio and the desired reagent concentrations would be achieved following mixing. Reagents used for preparation of leaching solutions included deionized water, 4.0 $\mathrm{M} \mathrm{NaOH}$ (Baker Analyzed reagent, lot V29501), solid $\mathrm{NaNO}_{3}\left(\mathrm{EM}\right.$ Science, lot 41227), and TEA [ $\left(\mathrm{HOCH}_{2} \mathrm{CH}_{2}\right)_{3} \mathrm{~N}$, Aldrich Chemical Co. $)$. 
Because the glove-box apparatus supported simultaneous leaching of two sludge samples, the samples were retrieved from the storage vault in pairs. Preweighed stir bars were added to the bottle containing the sludge. The reagents were transferred from a preweighed transfer bottle to be mixed with the sludge, which had previously been weighed during hot-cell operations. The lid on the sludge-containing bottle was then sealed, and both it and the transfer bottle were weighed to verify transfer of the proper amount of reagent. The sludge was then well mixed with the aid of the vortex mixer, and the bottle was placed in the sample-receiving slot of the preheated aluminum block.

The sludge samples were checked at least twice per day to verify that sludge was mixed and that the system was operating properly. It was noted that the rotational speed of the magnetic stir was dampened when the aluminum blocks were in place on the hot plate/stirrer. To ensure that the sludge made good contact with the leach solution, the sludge was mixed manually each time the samples were checked. Each sample was leached for at least 10 days. In the first day or two of processing, it was noted that the sludge would partially settle, producing a clarified layer of solution at the top of the sample. After that time, the settling rate seemed to decrease, because the solution did not clarify. However, there did appear to be settling of sludge at the bottom of the bottle. This change in settling character may be indicative of a decreasing particle size.

Sampling frequency for the first two sludge samples was at 1, 2, 4, 6.7, and 10 days. The remaining sludge samples were obtained at $0.3,1,2,4$, and $11+$ days. Initially sampling was accomplished by withdrawing a portion of the clarified liquid with a mechanical pipettor. This appeared to work well, with very little carryover of visible particles. Only the first four liquid samples from the first two sludge leaching tests were obtained in this manner. When it was observed that the solids settling rate slowed, the sampling method was changed to support filtering of the leachate. Liquid samples were withdrawn with $5 \mathrm{~cm}^{3}$ syringes fitted with an - 3-in. length of 1/8-in. ID Tygon ${ }^{\circledR}$ tubing to reach down to the liquid in the centrifuge bottle. Approximate liquid volumes withdrawn were $1.4 \mathrm{~mL}$ for each sample. While the liquid was in the syringe, the tubing was removed and replaced with a 0.22-Fm-porosity filter (Millipore Millex ${ }^{\circledR}-\mathrm{GS}$ ). All but one of the samples were filtered with ease. In each case the filtered sample was collected in preweighed polyethylene bottles. A final weighing was performed to verify that $1 \mathrm{~g}$ or more of leachate was obtained.

Prior to each sample withdrawal, the centrifuge bottle was removed from the hot plate and placed in a tungsten holder. Cooling was necessary to prevent loss of the TEA through evaporation when the centrifuge bottle was opened. The holder provided shielding while the leachate was sampled. At the end of sampling, the lid of the centrifuge bottle was securely replaced. The sludge was then mixed vigorously with manual shaking before the test specimen was returned to the hot plate/stirrer.

One sludge sample was dried at $60 \mathrm{EC}$ to ascertain the moisture content by successive weighings. It reached a constant weight after less than 1 day. The temperature was increased successively to 80,90 , and $105 \mathrm{EC}$ with no further weight loss. After drying at the highest temperature, the polypropylene copolymer (PPCO) centrifuge bottle was observed to crack, which was presumably due to both intense beta exposure and the high temperature. Deterioration was not visually evident on any of the other sludge samples, which all remained well wetted with free water and were not heated above $80 \mathrm{EC}$. 


\subsection{ANALYTICAL METHODS}

\subsubsection{Preliminary Characterization of Sludge Samples}

Obtaining uniform aliquots of sludge during the hot-cell operations was very important to the subsequent analysis of the sludge and to the leaching tests: that is, analysis of one sludge sample would suffice to determine concentrations of various components in the sludge, leaving all the other samples for use in the leaching study. Uniform aliquots were verified by weighing the wet sludge after the supernatant was decanted (see Sect. 3.1) and with on-site measurement of the ${ }^{60} \mathrm{Co},{ }^{137} \mathrm{Cs}$, ${ }^{154} \mathrm{Eu}$, and ${ }^{155} \mathrm{Eu}$ content in each sample. The gamma-counting system consisted of an ORTEC model GMX-45220-P-S intrinsic germanium detector, an ORTEC model 672 counting system amplifier, a Canberra Accuspec-A MCA card, and Canberra Genie-2000 spectroscopy software running on an IBM personal computer.

\subsubsection{Analysis of Sludge and Leachates}

Because the targeted species for the leaching studies was aluminum, it was the most important component for which to analyze. The methods used also provided data on other metal species with little additional effort. It was also decided that information on the extent of the solubilization of the radionuclides would be important to verify that the aluminum was selectively leached and separated from the high-level sludge.

Analytical methods that were used by the CSD personnel for this study were similar to those previously described in an ORNL report (Keller et al., 1996). Samples of sludge solids were solubilized by a microwave digestion with nitric acid, based on SW-846 Method 3051, Microwave Assisted Acid Digestion of Sediments, Sludges, Soils, and Oils. This method is considered by regulatory agencies to be a total digestion for metals and radionuclides. However, a simple nitric acid treatment will not dissolve most siliceous materials. Therefore, the residue after the microwave-assisted acid digestion was assumed to be silicon dioxide.

The leachates and wash solutions were filtered, if not already filtered when obtained from the test. Each sample was analyzed by gamma spectrometry for most of the radionuclides and by ICP-AES for metals. Gross alpha and total activity analyses were also performed on the last sample taken from each leaching experiment to ascertain the overall separation of the aluminum from the radionuclides. The analytical error for the metal measurements depends upon the analytical method, the concentration level and dilution factors, and the sample matrix. ICP-AES is a multiple-element measurement technique designed for the best average performance for all elements and is not optimized for any single component. Analysis for anions was not performed.

The standard radiochemical methods for radioactive waste characterization are EPA Method 600/900.0, Gross Alpha and Beta Radioactivity in Drinking Water, and EPA Method 600/901.1, Gamma Emitting Radionuclides in Drinking Water. EPA Method 901.1 was used to determine ${ }^{60} \mathrm{Co}$, ${ }^{134} \mathrm{Cs},{ }^{137} \mathrm{Cs},{ }^{152} \mathrm{Eu},{ }^{154} \mathrm{Eu},{ }^{155} \mathrm{Eu}$, and ${ }^{241} \mathrm{Am}$. Gross beta measurements were obtained by liquid scintillation counting. 



\section{RESULTS AND DISCUSSION}

\subsection{OBSERVATION AND CHARACTERIZATION OF SLUDGE SAMPLES}

A total of 21 samples were prepared from the $32.50 \mathrm{~g}$ of as-received dry sludge that SRS sent to ORNL. Sample aliquots of - $20 \mathrm{~mL}$ and $-30 \mathrm{~mL}$ were prepared with target sludge contents of approximately 1.5 and $2.0 \mathrm{~g}$ of dry (i.e., as-received) sludge, respectively. Samples \#01-\#10 and \#17-\#18 were prepared with aliquots of - $20 \mathrm{~mL}$ of sludge slurry. After these 12 samples were centrifuged and the supernatant decanted, each sample contained $4.37 \mathrm{~g}( \pm 0.07 \mathrm{~g})$ of wet sludge. Samples \#11-\#16 were prepared with aliquots of - $30 \mathrm{~mL}$ of sludge slurry. These six samples were centrifuged, and the supernatant decanted to obtain samples containing $5.69 \mathrm{~g}( \pm 0.14 \mathrm{~g})$ of wet sludge. Three additional odd-sized samples were produced when the final amounts of sludge were dispensed and the mixing vessel was rinsed. The dried rocky debris described in Sect. 3.1.2, which had a total dry mass of $0.81 \mathrm{~g}$, was saved as an additional sample for potential further analysis. Table 4.1 summarizes the wet mass of each sample produced.

The amount of water retained by the centrifuged wet sludge can be estimated. The density of the inhibited water is very close to that of water, and the masses of the solutes $(\mathrm{NaOH}$ and $\mathrm{NaNO}_{2}$ ) are negligible at the concentrations and volumes involved. The assumptions made are that (1) no sludge was lost during the transfers between containers and the sludge was completely recovered by rinsing of the mixing vessel; (2) the inhibited water dissolved a negligible amount of the sludge; and (3) after drying at room temperature, the rocky debris had the same moisture content as it did when it arrived with the sludge. Consequently, the 21 wet sludge samples contained $31.69 \mathrm{~g}$ of the $32.50 \mathrm{~g}$ of sludge received. The total mass of the wet sludge samples was $89.21 \mathrm{~g}$. Thus, the ratio of dry sludge to wet sludge was $0.3552 \mathrm{~g} / \mathrm{g}$, which is equivalent to a water content of $64.48 \mathrm{wt} \%$. The dry sludge contents of the two different-sized samples were thus $1.55 \mathrm{~g}( \pm 0.03 \mathrm{~g})$ and $2.02 \mathrm{~g} \mathrm{(} \pm 0.05 \mathrm{~g})$, which were very close to the target values.

Results of the gamma-counting analysis performed with the on-site ORTEC/Canberra system (described in Sect. 3.3.2) are also summarized in Table 4.1. The primary radionuclides detected were ${ }^{60} \mathrm{Co},{ }^{137} \mathrm{Cs},{ }^{154} \mathrm{Eu}$, and ${ }^{155} \mathrm{Eu}$. Because of its low concentration, ${ }^{155} \mathrm{Eu}$ was not always detected. Strong peaks were observed for ${ }^{137} \mathrm{Cs}$ and ${ }^{154} \mathrm{Eu}$. Consistency in the measured activity for similarsized samples indicated that the samples were very uniform after processing through the mixing equipment. A sample of the composite wash solution was also analyzed and the result is also listed in Table 4.1.

\subsection{EFFECT OF WASHING SLUDGE}

As discussed in Sect. 3.1.2, inhibited water (aqueous solution of $0.01 \mathrm{MNaOH}$ and $0.01 \mathrm{M}$ $\mathrm{NaNO}_{2}$ ) was used to transfer the sludge from the shipping containers and to provide a medium for producing a slurry of sludge suitable for subdividing into several uniform aliquots. The equivalent of two washing operations was performed. During the transfer operation - $150 \mathrm{~mL}$ of inhibited water was used. The sludge was well contacted with the solution and allowed to sit for - 11 days before separation. During the sample preparation $-400 \mathrm{~mL}$ of inhibited water was used, and the 
solution was in contact with the sludge for $>16 \mathrm{~h}$. In each case, most of the liquid was separated from the sludge by centrifugation and decantation. The clarified liquids were accumulated in one large sample bottle (referred to as the composite wash solution) and mixed well before sampling and analysis. The total mass of wash solution collected was $518.67 \mathrm{~g}$.

Table 4.1. Summary characterization of centrifuged wet sludge samples

\begin{tabular}{|c|c|c|c|c|c|c|c|c|c|}
\hline \multirow{3}{*}{$\begin{array}{c}\text { Sample } \\
\text { ID }\end{array}$} & \multirow{3}{*}{$\begin{array}{l}\text { Mass wet } \\
\text { sludge (g) }\end{array}$} & \multicolumn{8}{|c|}{ Measured activity (FCi/g) } \\
\hline & & \multicolumn{2}{|c|}{${ }^{60} \mathrm{Co}$} & \multicolumn{2}{|c|}{${ }^{137} \mathrm{Cs}$} & \multicolumn{2}{|c|}{${ }^{154} \mathrm{Eu}$} & \multicolumn{2}{|c|}{${ }^{155} \mathrm{Eu}$} \\
\hline & & Value & $\%$ Error & Value & $\%$ Error & Value & $\%$ Error & Value & $\%$ Error \\
\hline 01 & 4.45 & 0.209 & 6.56 & 11.6 & 5.08 & 12.6 & 1.17 & 1.76 & 5.76 \\
\hline 02 & 4.34 & 0.233 & 5.90 & 10.6 & 5.07 & 12.9 & 1.13 & $a$ & $a$ \\
\hline 03 & 4.50 & 0.212 & 6.16 & 10.2 & 5.08 & 12.5 & 1.13 & 1.54 & 5.77 \\
\hline 04 & 4.46 & 0.190 & 7.05 & 10.1 & 5.08 & 12.6 & 1.13 & $a$ & $a$ \\
\hline 05 & 4.31 & 0.203 & 6.48 & 10.3 & 5.08 & 12.5 & 1.15 & 1.58 & 5.77 \\
\hline 06 & 4.33 & 0.222 & 6.49 & 10.4 & 5.09 & 12.6 & 1.13 & 1.70 & 5.61 \\
\hline 07 & 4.39 & 0.224 & 6.63 & 9.98 & 5.09 & 12.5 & 1.20 & $a$ & $a$ \\
\hline 08 & 4.37 & 0.207 & 6.05 & 10.1 & 5.07 & 12.6 & 1.12 & 1.55 & 5.72 \\
\hline 09 & 4.34 & 0.191 & 7.90 & 10.2 & 5.09 & 12.8 & 1.15 & $a$ & $a$ \\
\hline 10 & 4.39 & 0.212 & 6.12 & 10.4 & 5.08 & 13.0 & 1.12 & 1.69 & 5.70 \\
\hline 11 & 5.65 & 0.193 & 7.28 & 9.84 & 5.08 & 12.0 & 1.15 & 1.68 & 5.57 \\
\hline 12 & 5.71 & 0.197 & 8.46 & 9.51 & 5.08 & 11.8 & 1.19 & $a$ & $a$ \\
\hline 13 & 5.87 & 0.215 & 6.86 & 9.18 & 5.08 & 11.4 & 1.15 & $a$ & $a$ \\
\hline 14 & 5.75 & 0.186 & 7.60 & 9.48 & 5.08 & 11.8 & 1.16 & $a$ & $a$ \\
\hline 15 & 5.70 & 0.221 & 6.18 & 9.69 & 5.08 & 12.0 & 1.14 & 1.46 & 5.91 \\
\hline 16 & 5.45 & 0.176 & 7.53 & 9.72 & 5.08 & 12.1 & 1.16 & $a$ & $a$ \\
\hline 17 & 4.24 & $b$ & $b$ & $b$ & $b$ & $b$ & $b$ & $b$ & $b$ \\
\hline 18 & 4.30 & $b$ & $b$ & $b$ & $b$ & $b$ & $b$ & $b$ & $b$ \\
\hline 19 & 2.26 & $b$ & $b$ & $b$ & $b$ & $b$ & $b$ & $b$ & $b$ \\
\hline 20 & 0.22 & $b$ & $b$ & $b$ & $b$ & $b$ & $b$ & $b$ & $b$ \\
\hline 21 & 0.18 & $b$ & $b$ & $b$ & $b$ & $b$ & $b$ & $b$ & $b$ \\
\hline $33^{c}$ & 0.81 & $a$ & $a$ & 20.9 & 5.08 & 3.54 & 2.18 & $a$ & $a$ \\
\hline COMP-1-S & $25^{d}$ & $a$ & $a$ & 1.59 & 5.05 & $a$ & $a$ & $a$ & $a$ \\
\hline
\end{tabular}

${ }^{a}$ Amount detected not statistically significant.

${ }^{b}$ Not measured.

${ }^{c}$ Sample 33 is rocky material screened from the sludge.

${ }^{d}$ COMP-1-S is a composite supernatant sample of $-25 \mathrm{~mL}$.

Analysis of the composite wash solution was used to identify those components that were removed from the sludge. This information may be combined with an analysis of the sludge to 
estimate the composition of the original as-received sludge and to calculate the fraction of each component removed. Table 4.2 provides the analysis of the sludge and wash solution and includes values calculated from Eqs. (4.1)-(4.3). In Sect. 4.1, the ratio of dry sludge to wet sludge was estimated at $0.3552 \mathrm{~g} / \mathrm{g}$, under the assumption that a negligible amount of sludge dissolved during washing. The concentration of each component in the dry sludge was calculated from

$$
c_{i, d r y}=c_{i, w e t} / \chi / 10^{6} \text {, }
$$

where $c_{i, d r y}=$ concentration of component $i$ in the dry solids, $\mathrm{g} / \mathrm{g}$;

$c_{i, w e t}=$ concentration of component $i$ in the wet solids, $\mathrm{Fg} / \mathrm{g}$;

$\chi=$ ratio of dry sludge mass to wet sludge mass, $0.3552 \mathrm{~g} / \mathrm{g}$.

All metals in the wash solution, other than sodium, originated from the sludge. Therefore, the total amount of each component was calculated by

$$
m_{i}=m_{s} c_{i, d r y}+V_{l} c_{i, l} / 10^{6}
$$

where $m_{i}=$ total mass of component $i$ in the original sludge, $\mathrm{g}$;

$m_{s}=$ total mass of dry sludge solids, g;

$V_{l}=$ volume of decanted wash liquid, $\mathrm{mL}$;

$c_{i, l}=$ concentration of component $i$ in the wash liquid, $\mathrm{Fg} / \mathrm{mL}$.

The fraction of each component dissolved in the wash solution was calculated with

$$
f_{i}=\left(V_{l} c_{i, l} / 10^{6}\right) / m_{i},
$$

where $f_{i}=$ the fraction of each component dissolved by the wash solution.

Calculated values of the composition of the washed sludge on a dry basis and the fraction of the original sludge dissolved by the wash solution are also listed in Table 4.2. (The composition of the original sludge is not given separately in this table.)

Except for two metals, the concentrations of all process metals in the wash solution were below the detectable limit. The calculated values indicate that $-0.027 \%$ of the aluminum and $-11 \%$ of the calcium dissolved in the wash solution. Both values are insignificant, because only a small amount of aluminum was removed and because calcium was a minor constituent in the original sludge. Cesium-137 was the only radionuclide significantly washed from the sludge; $-42.2 \%$ of the ${ }^{137} \mathrm{Cs}$ was removed. Because of the high activity of ${ }^{137} \mathrm{Cs}$, its total mass is a negligible fraction of the mass of the sludge. The original assumption, that the mass of material dissolved by the wash solution is negligible, is thus confirmed. Table 4.3 compares the concentration of selected sludge components estimated by SRS and ORNL.

The composition obtained by SRS is from a direct analysis of the sludge. Values estimated in this study are calculated from analyses of the washed wet sludge and wash solution using Eq. (4.2) and knowledge of the total mass of dry sludge received. The two analyses compared very well when the measurements were within the range of the instruments. The large dilution ratios needed to obtain good results on the target metals caused difficulties with the minor constituents. For example, at the limits of detection, there would be $1.7 \mathrm{mg}$ of uranium per gram of dry sludge. Analysis indicates less than this amount, which disagrees with results of the analysis performed by SRS. 
Table 4.2. Analysis of sludge and wash solution and calculated fraction of components dissolved

\begin{tabular}{|c|c|c|c|c|c|c|}
\hline \multirow[b]{2}{*}{ Analyte } & \multicolumn{3}{|c|}{ Sludge $^{a}$} & \multicolumn{2}{|c|}{ Wash solution $^{b}$} & \multirow[b]{2}{*}{ Fraction dissolved $^{d}$} \\
\hline & Result & Error & Dry basis $^{c}$ & Result & Error & \\
\hline Metals & $\mathrm{Fg} / \mathrm{g}$ & $\mathrm{Fg} / \mathrm{g}$ & $\mathrm{g} / \mathrm{g}$ & $\mathrm{Fg} / \mathrm{mL}$ & $\mathrm{Fg} / \mathrm{mL}$ & $\mathrm{g} / \mathrm{g}$ \\
\hline $\mathrm{Ag}$ & $2.51 \mathrm{E}+01$ & $5.00 \mathrm{E}+00$ & $7.07 \mathrm{E}-05$ & $<1.70 \mathrm{E}+00$ & $e$ & $f$ \\
\hline $\mathrm{Al}$ & $1.08 \mathrm{E}+05$ & $1.10 \mathrm{E}+04$ & $3.04 \mathrm{E}-01$ & $5.00 \mathrm{E}+00$ & $1.00 \mathrm{E}+00$ & $2.69 \mathrm{E}-04$ \\
\hline $\mathrm{Ba}$ & $2.74 \mathrm{E}+02$ & $2.70 \mathrm{E}+01$ & 7.71E-04 & $<2.00 \mathrm{E}-01$ & $e$ & $f$ \\
\hline $\mathrm{Be}$ & $<1.14 \mathrm{E}+00$ & $e$ & $f$ & $<1.00 \mathrm{E}-01$ & $e$ & $f$ \\
\hline $\mathrm{Ca}$ & $1.66 \mathrm{E}+03$ & $1.70 \mathrm{E}+02$ & $4.67 \mathrm{E}-03$ & $3.54 \mathrm{E}+01$ & $3.50 \mathrm{E}+00$ & $1.10 \mathrm{E}-01$ \\
\hline $\mathrm{Cd}$ & $<1.85 \mathrm{E}+02$ & $e$ & $f$ & $<1.62 \mathrm{E}+01$ & $e$ & $f$ \\
\hline $\mathrm{Co}$ & $<1.14 \mathrm{E}+02$ & $e$ & $f$ & $<1.00 \mathrm{E}+01$ & $e$ & $f$ \\
\hline $\mathrm{Cr}$ & $3.31 \mathrm{E}+01$ & $6.60 \mathrm{E}+00$ & $9.32 \mathrm{E}-05$ & $<2.10 \mathrm{E}+00$ & $e$ & $f$ \\
\hline $\mathrm{Cu}$ & $1.96 \mathrm{E}+02$ & $2.00 \mathrm{E}+01$ & $5.52 \mathrm{E}-04$ & $<7.00 \mathrm{E}-01$ & $e$ & $f$ \\
\hline $\mathrm{Fe}$ & $1.12 \mathrm{E}+04$ & $1.10 \mathrm{E}+03$ & $3.15 \mathrm{E}-02$ & $<1.05 \mathrm{E}+01$ & $e$ & $f$ \\
\hline $\mathrm{K}$ & $<2.85 \mathrm{E}+02$ & $e$ & $f$ & $<2.50 \mathrm{E}+01$ & $e$ & $f$ \\
\hline $\mathrm{Mg}$ & $5.59 \mathrm{E}+02$ & $1.12 \mathrm{E}+02$ & $1.57 \mathrm{E}-03$ & $<1.06 \mathrm{E}+01$ & $e$ & $f$ \\
\hline $\mathrm{Mn}$ & $7.07 \mathrm{E}+03$ & $7.10 \mathrm{E}+02$ & 1.99E-02 & $<2.00 \mathrm{E}-01$ & $e$ & $f$ \\
\hline $\mathrm{Ni}$ & $2.57 \mathrm{E}+03$ & $2.60 \mathrm{E}+02$ & 7.23E-03 & $<5.00 \mathrm{E}+00$ & $e$ & $f$ \\
\hline $\mathrm{Sb}$ & $<7.07 \mathrm{E}+01$ & $e$ & $f$ & $<6.20 \mathrm{E}+00$ & $e$ & $f$ \\
\hline $\mathrm{Th}$ & $1.88 \mathrm{E}+03$ & $1.90 \mathrm{E}+02$ & $5.29 \mathrm{E}-03$ & $<2.51 \mathrm{E}+01$ & $e$ & $f$ \\
\hline $\mathrm{U}$ & $<3.86 \mathrm{E}+02$ & $e$ & $f$ & $<3.39 \mathrm{E}+01$ & $e$ & $f$ \\
\hline $\mathrm{V}$ & $<7.07 \mathrm{E}+01$ & $e$ & $f$ & $<6.20 \mathrm{E}+00$ & $e$ & $f$ \\
\hline $\mathrm{Zn}$ & $<6.58 \mathrm{E}+02$ & $e$ & $f$ & $<5.77 \mathrm{E}+01$ & $e$ & $f$ \\
\hline Radionuclides & $\mathrm{Bq} / \mathrm{g}$ & $\mathrm{Bq} / \mathrm{g}$ & $\mathrm{Bq} / \mathrm{g}$ & $\mathrm{Bq} / \mathrm{mL}$ & $\mathrm{Bq} / \mathrm{mL}$ & $\mathrm{Bq} / \mathrm{Bq}$ \\
\hline Co-60 & $1.20 \mathrm{E}+04$ & $2.00 \mathrm{E}+03$ & $3.38 \mathrm{E}+04$ & $e$ & $e$ & $f$ \\
\hline Cs-137 & $5.50 \mathrm{E}+05$ & $1.00 \mathrm{E}+04$ & $1.55 \mathrm{E}+06$ & $6.90 \mathrm{E}+04$ & $1.00 \mathrm{E}+03$ & $4.22 \mathrm{E}-01$ \\
\hline $\mathrm{Eu}-152$ & $3.70 \mathrm{E}+04$ & $9.00 \mathrm{E}+03$ & $1.04 \mathrm{E}+05$ & $e$ & $e$ & $f$ \\
\hline Eu-154 & $6.90 \mathrm{E}+05$ & $2.00 \mathrm{E}+04$ & $1.94 \mathrm{E}+06$ & $e$ & $e$ & $f$ \\
\hline Eu-155 & $6.70 \mathrm{E}+04$ & $1.80 \mathrm{E}+04$ & $1.89 \mathrm{E}+05$ & $e$ & $e$ & $f$ \\
\hline Gross alpha & $1.00 \mathrm{E}+07$ & $1.00 \mathrm{E}+06$ & $2.82 \mathrm{E}+07$ & $2.60 \mathrm{E}+03$ & $1.00 \mathrm{E}+02$ & $1.51 \mathrm{E}-03$ \\
\hline Total activity & $3.90 \mathrm{E}+08$ & $1.00 \mathrm{E}+07$ & $1.10 \mathrm{E}+09$ & $8.80 \mathrm{E}+04$ & $1.00 \mathrm{E}+03$ & $1.31 \mathrm{E}-03$ \\
\hline
\end{tabular}

${ }^{a}$ Sludge sample \#10, analysis is on basis of washed wet sludge.

${ }^{b}$ Composite wash solution sample COMP-1-S.

${ }^{c}$ Concentration corrected to dry mass of sludge (assuming washing dissolved a negligible amount of the as-received sludge).

${ }^{d}$ Based on total mass of dry (as-received) sludge of $31.69 \mathrm{~g}$ and a total wash solution mass of $518.67 \mathrm{~g}$ that has an assumed density of $1.0 \mathrm{~g} / \mathrm{mL}$.

${ }^{e}$ Not applicable because value is below detectable limit.

${ }^{f}$ Not computed because required measured values are below detection limit.

\subsection{LEACHING WITH CAUSTIC AND CAUSTIC-CHELATING AGENTS}

Six leaching tests were performed with the sludge aliquots described in Sect. 4.1. The ratio of sludge to liquid leaching solution was selected so the leachate concentration would not be the limiting factor for the aluminum. Two sizes of sludge aliquots were available for the tests. The first 
Table 4.3. Comparison of SRS and ORNL analyses of tank 12H sludge for selected components

\begin{tabular}{|c|c|c|}
\hline Component & Amount $/ \mathbf{g}^{a}$ & Amount $/ \mathbf{g}^{b}$ \\
\hline \multicolumn{3}{|l|}{ Process metals } \\
\hline $\mathrm{Al}$ & $0.304 \mathrm{~g}$ & $0.304 \mathrm{~g}$ \\
\hline $\mathrm{Ba}$ & $0.0005 \mathrm{~g}$ & $0.000771 \mathrm{~g}$ \\
\hline $\mathrm{Fe}$ & $0.038 \mathrm{~g}$ & $0.0315 \mathrm{~g}$ \\
\hline $\mathrm{Hg}$ & $0.008 \mathrm{~g}$ & $c$ \\
\hline $\mathrm{K}$ & $0.002 \mathrm{~g}$ & $c$ \\
\hline $\mathrm{Mg}$ & $0.002 \mathrm{~g}$ & $0.00157 \mathrm{~g}$ \\
\hline $\mathrm{Mn}$ & $0.018 \mathrm{~g}$ & $0.0199 \mathrm{~g}$ \\
\hline $\mathrm{Ni}$ & $0.005 \mathrm{~g}$ & $0.00723 \mathrm{~g}$ \\
\hline \multicolumn{3}{|l|}{ Radionuclides } \\
\hline Сo-60 & $0.0014 \mathrm{mCi}$ & $0.000914 \mathrm{mCi}$ \\
\hline Sr-90 & $14.9 \mathrm{mCi}$ & $c$ \\
\hline Cs- 137 & $0.081 \mathrm{mCi}$ & $0.0724 \mathrm{mCi}$ \\
\hline Eu-154 & $0.0623 \mathrm{mCi}$ & $0.0524 \mathrm{mCi}$ \\
\hline Eu-155 & $0.0094 \mathrm{mCi}$ & $0.00511 \mathrm{mCi}$ \\
\hline U-all & $3.3 \mathrm{mg}$ & $c$ \\
\hline $\mathrm{Pu}-238$ & $0.61 \mathrm{mCi}$ & $c$ \\
\hline $\mathrm{Pu}-239$ & $0.012 \mathrm{mCi}$ & $c$ \\
\hline $\mathrm{Pu}-241$ & $0.845 \mathrm{mCi}$ & $c$ \\
\hline Am-241 & $0.031 \mathrm{mCi}$ & $c$ \\
\hline
\end{tabular}

${ }^{a}$ Fondeur, 2001.

${ }^{b}$ This work, in which measured units of becquerels were converted to millicuries by dividing by $3.7 \times 10^{4}$.

${ }^{c}$ Not measured or below detectable limit.

two tests were performed with the larger aliquot size (e.g., those containing the equivalent of $2.02 \mathrm{~g}$ of dry sludge). With the volume available in the test equipment, the maximum permitted ratio of sludge to leaching solution was $-1: 15$. The same ratio was used for leaching tests using the smaller sludge aliquot size (e.g., those containing the equivalent of $1.55 \mathrm{~g}$ of dry sludge). Each sample was leached for a period of at least 10 days with samples taken at intervals throughout that period. Table 4.4 summarizes the actual conditions of the six tests and identifies the sludge sample used in each test.

The liquid leaching-solution samples were analyzed for metal cations with ICP-AES, and radionuclides were determined with gamma spectrum, gross alpha, and total activity counting methods. The results are shown in Tables 4.5 through 4.10. A review of the data reveals that many of the analytes were below the detectable limit. Aluminum and cesium are detected in all leachates. Other metals and radionuclides appear in some of the tests in which TEA was present. 
Table 4.4. Actual sludge samples used and the actual conditions of the tests

\begin{tabular}{|c|c|c|c|c|c|c|}
\hline \multirow[b]{2}{*}{ Test } & \multirow{2}{*}{$\begin{array}{c}\text { Temp. } \\
\text { (EC) }\end{array}$} & \multirow{2}{*}{$\begin{array}{c}\text { Sludge } \\
\text { sample ID }^{a}\end{array}$} & \multirow{2}{*}{$\begin{array}{c}\text { Sludge:Leaching } \\
\text { solution } \\
(\mathrm{g} / \mathrm{g}) \\
\end{array}$} & \multicolumn{3}{|c|}{ Concn. in leaching solution (m) } \\
\hline & & & & $\mathrm{NaOH}$ & TEA $^{b}$ & $\mathrm{NaNO}_{3}$ \\
\hline 1 & 80 & 12 & $1: 14.9$ & 3.0 & 0 & 0 \\
\hline 2 & 60 & 11 & $1: 14.9$ & 3.0 & 0 & 0 \\
\hline 3 & 60 & 9 & $1: 14.9$ & 3.0 & 0.1 & 0 \\
\hline 4 & 60 & 8 & $1: 14.9$ & 3.0 & 3.0 & 0 \\
\hline 5 & 60 & 6 & $1: 14.9$ & 0.1 & 0 & 2.9 \\
\hline 6 & 60 & 7 & $1: 14.9$ & 0.1 & 0.1 & 2.9 \\
\hline
\end{tabular}

${ }^{a}$ Sludge sample numbers as defined in Table 4.1 .

${ }^{b}$ Triethanolamine.

\subsubsection{Removal of Aluminum from the Sludge}

The concentration of aluminum in all the leachates from all six experiments is shown in Fig. 4.1 as a function of time. Experiments using $3.0 \mathrm{~m} \mathrm{NaOH}$ as the leaching solution at $60 \mathrm{EC}$ and 80EC (using samples \#11 and \#12, respectively) were performed to observe the effect of temperature. At the higher temperature the aluminum concentration rises more rapidly and achieves a higher final concentration. The decrease in concentration at the last point on the curve for the $80 \mathrm{EC}$ test is likely an artifact of analytical error. In both cases, it appears that the solubility limit of aluminum is approached. At $60 \mathrm{EC}$ the maximum concentration is reached in - 8-10 days, while at $80 \mathrm{EC}$ the maximum is achieved in - 6 days.

Two leaching tests with $3.0 \mathrm{~m} \mathrm{NaOH}$ were performed at a temperature of $60 \mathrm{EC}$ using $0.1 \mathrm{~m}$ TEA and $3.0 \mathrm{~m}$ TEA. As shown in Fig. 4.1, the leaching power of the $3.0 \mathrm{~m} \mathrm{NaOH}-0.1 \mathrm{~m}$ TEA solution lies between the results obtained at $60 \mathrm{EC}$ and $80 \mathrm{EC}$ using $3.0 \mathrm{~m} \mathrm{NaOH}$ alone. At the end of the 10-day test, the rate of rise in aluminum concentration had decreased, but the limiting value had not yet been reached. The concentration of aluminum in the leachate using the $3.0 \mathrm{~m}$ $\mathrm{NaOH}-3.0 m$ TEA solution continued to rise rapidly even after 10 days. The aluminum concentration clearly exceeded the values obtained in all the other tests. The fraction of aluminum dissolved at $60 \mathrm{EC}$ increased from - $35 \%$ using $3.0 \mathrm{~m} \mathrm{NaOH}$ alone to $-87 \%$ using a combination of $3.0 \mathrm{~m} \mathrm{NaOH}$ and $3.0 \mathrm{~m}$ TEA.

The last two tests with $0.1 \mathrm{~m} \mathrm{NaOH}-2.9 m \mathrm{NaNO}_{3}$ were performed at a temperature of $60 \mathrm{EC}$; one was conducted using no TEA, and $0.1 \mathrm{~m}$ TEA was used in the other. As shown in Fig. 4.1, the aluminum concentration in the leachate increased slowly and reached its limiting value in - 2 days. More aluminum dissolved when the TEA was used than when it was not present. However, in either case the aluminum concentration was lower than in the other tests performed with a higher $\mathrm{NaOH}$ concentration. 
Table 4.5. Analysis of leachate solution: test at 3.0 $\mathrm{m} \mathrm{NaOH}, 80 \mathrm{EC}$, using sludge sample \#12 (results obtained at five run times)

\begin{tabular}{|c|c|c|c|c|c|c|c|c|c|c|}
\hline \multirow[b]{2}{*}{ Analyte } & \multicolumn{2}{|c|}{$\begin{array}{c}\text { Sample 12-1: } \\
1.073 \mathrm{~d}\end{array}$} & \multicolumn{2}{|c|}{$\begin{array}{c}\text { Sample 12-2: } \\
2.042 \mathrm{~d}\end{array}$} & \multicolumn{2}{|c|}{$\begin{array}{c}\text { Sample 12-3: } \\
4.083 \mathrm{~d}\end{array}$} & \multicolumn{2}{|c|}{$\begin{array}{c}\text { Sample 12-4: } \\
6.743 \mathrm{~d}\end{array}$} & \multicolumn{2}{|c|}{$\begin{array}{c}\text { Sample 12-5: } \\
10.000 \mathrm{~d}\end{array}$} \\
\hline & Result & Error & Result & Error & Result & Error & Result & Error & Result & Error \\
\hline Metals & $\mathrm{Fg} / \mathrm{mL}$ & $\mathrm{Fg} / \mathrm{mL}$ & $\mathrm{Fg} / \mathrm{mL}$ & $\mathrm{Fg} / \mathrm{mL}$ & $\mathrm{Fg} / \mathrm{mL}$ & $\mathrm{Fg} / \mathrm{mL}$ & $\mathrm{Fg} / \mathrm{mL}$ & $\mathrm{Fg} / \mathrm{mL}$ & $\mathrm{Fg} / \mathrm{mL}$ & $\mathrm{Fg} / \mathrm{mL}$ \\
\hline $\mathrm{Ag}$ & $<1.70 \mathrm{E}+00$ & $a$ & $<1.70 \mathrm{E}+00$ & $a$ & $<1.70 \mathrm{E}+00$ & $a$ & $<1.70 \mathrm{E}+00$ & $a$ & $<1.70 \mathrm{E}+00$ & $a$ \\
\hline $\mathrm{Al}$ & $3.33 \mathrm{E}+03$ & $3.30 \mathrm{E}+02$ & $8.63 \mathrm{E}+03$ & $8.60 \mathrm{E}+02$ & $1.12 \mathrm{E}+04$ & $1.10 \mathrm{E}+03$ & $1.18 \mathrm{E}+04$ & $1.20 \mathrm{E}+03$ & $1.00 \mathrm{E}+04$ & $1.00 \mathrm{E}+03$ \\
\hline $\mathrm{Ba}$ & $1.00 \mathrm{E}+00$ & $2.00 \mathrm{E}-02$ & $1.00 \mathrm{E}+00$ & $2.00 \mathrm{E}-01$ & $8.00 \mathrm{E}-01$ & $1.60 \mathrm{E}-01$ & $8.00 \mathrm{E}-01$ & $1.60 \mathrm{E}-01$ & $8.00 \mathrm{E}-01$ & $1.60 \mathrm{E}-01$ \\
\hline $\mathrm{Be}$ & $<1.00 \mathrm{E}-01$ & $a$ & $<1.00 \mathrm{E}-01$ & $a$ & $<1.00 \mathrm{E}-01$ & $a$ & $<1.00 \mathrm{E}-01$ & $a$ & $<1.00 \mathrm{E}-01$ & $a$ \\
\hline $\mathrm{Ca}$ & $4.97 \mathrm{E}+01$ & $5.00 \mathrm{E}+00$ & $1.55 \mathrm{E}+01$ & $1.60 \mathrm{E}+00$ & $<3.00 \mathrm{E}+00$ & $a$ & $1.25 \mathrm{E}+01$ & $2.50 \mathrm{E}+00$ & $6.40 \mathrm{E}+00$ & $1.28 \mathrm{E}+00$ \\
\hline $\mathrm{Cd}$ & $<1.62 \mathrm{E}+01$ & $a$ & $<1.62 \mathrm{E}+01$ & $a$ & $<1.62 \mathrm{E}+01$ & $a$ & $<1.62 \mathrm{E}+01$ & $a$ & $<1.62 \mathrm{E}+01$ & $a$ \\
\hline $\mathrm{Co}$ & $<1.00 \mathrm{E}+01$ & $a$ & $<1.00 \mathrm{E}+01$ & $a$ & $<1.00 \mathrm{E}+01$ & $a$ & $<1.00 \mathrm{E}+01$ & $a$ & $<1.00 \mathrm{E}+01$ & $a$ \\
\hline $\mathrm{Cr}$ & $<2.10 \mathrm{E}+00$ & $a$ & $<2.10 \mathrm{E}+00$ & $a$ & $<2.10 \mathrm{E}+00$ & $a$ & $<2.10 \mathrm{E}+00$ & $a$ & $<2.10 \mathrm{E}+00$ & $a$ \\
\hline $\mathrm{Cu}$ & $2.30 \mathrm{E}+00$ & $4.60 \mathrm{E}-01$ & $2.90 \mathrm{E}+00$ & $5.80 \mathrm{E}-01$ & $1.50 \mathrm{E}+00$ & $a$ & $<7.00 \mathrm{E}-01$ & $a$ & $8.00 \mathrm{E}-01$ & $1.60 \mathrm{E}-01$ \\
\hline $\mathrm{Fe}$ & $<1.05 \mathrm{E}+01$ & $a$ & $<1.05 \mathrm{E}+01$ & $a$ & $<1.05 \mathrm{E}+01$ & $a$ & $<1.05 \mathrm{E}+01$ & $a$ & $<1.05 \mathrm{E}+01$ & $a$ \\
\hline $\mathrm{K}$ & $3.26 \mathrm{E}+01$ & $6.50 \mathrm{E}+00$ & $3.04 \mathrm{E}+01$ & $6.10 \mathrm{E}+00$ & $<2.50 \mathrm{E}+01$ & $a$ & $<2.50 \mathrm{E}+01$ & $a$ & $<2.50 \mathrm{E}+01$ & $a$ \\
\hline $\mathrm{Mg}$ & $<1.06 \mathrm{E}+01$ & $a$ & $<1.06 \mathrm{E}+01$ & $a$ & $<1.06 \mathrm{E}+01$ & $a$ & $<1.06 \mathrm{E}+01$ & $a$ & $<1.06 \mathrm{E}+01$ & $a$ \\
\hline $\mathrm{Mn}$ & $<2.00 \mathrm{E}-01$ & $a$ & $<2.00 \mathrm{E}-01$ & $a$ & $<2.00 \mathrm{E}-01$ & $a$ & $<2.00 \mathrm{E}-01$ & $a$ & $<2.00 \mathrm{E}-01$ & $a$ \\
\hline $\mathrm{Ni}$ & $<5.00 \mathrm{E}+00$ & $a$ & $<5.00 \mathrm{E}+00$ & $a$ & $<5.00 \mathrm{E}+00$ & $a$ & $<5.00 \mathrm{E}+00$ & $a$ & $<5.00 \mathrm{E}+00$ & $a$ \\
\hline $\mathrm{Sb}$ & $<6.20 \mathrm{E}+00$ & $a$ & $<6.20 \mathrm{E}+00$ & $a$ & $<6.20 \mathrm{E}+00$ & $a$ & $<6.20 \mathrm{E}+00$ & $a$ & $<6.20 \mathrm{E}+00$ & $a$ \\
\hline $\mathrm{Th}$ & $<2.51 \mathrm{E}+01$ & $a$ & $<2.51 \mathrm{E}+01$ & $a$ & $<2.51 \mathrm{E}+01$ & $a$ & $<2.51 \mathrm{E}+01$ & $a$ & $<2.51 \mathrm{E}+01$ & $a$ \\
\hline $\mathrm{U}$ & $<3.39 \mathrm{E}+01$ & $a$ & $<3.39 \mathrm{E}+01$ & $a$ & $<3.39 \mathrm{E}+01$ & $a$ & $<3.39 \mathrm{E}+01$ & $a$ & $<3.39 \mathrm{E}+01$ & $a$ \\
\hline $\mathrm{V}$ & $<6.20 \mathrm{E}+00$ & $a$ & $<6.20 \mathrm{E}+00$ & $a$ & $<6.20 \mathrm{E}+00$ & $a$ & $<6.20 \mathrm{E}+00$ & $a$ & $<6.20 \mathrm{E}+00$ & $a$ \\
\hline $\mathrm{Zn}$ & $<5.77 \mathrm{E}+01$ & $a$ & $6.95 \mathrm{E}+01$ & $1.39 \mathrm{E}+01$ & $<5.77 \mathrm{E}+01$ & $a$ & $<5.77 \mathrm{E}+01$ & $a$ & $<5.77 \mathrm{E}+01$ & $a$ \\
\hline Radionuclides & $\mathrm{Bq} / \mathrm{mL}$ & $\mathrm{Bq} / \mathrm{mL}$ & $\mathrm{Bq} / \mathrm{mL}$ & $\mathrm{Bq} / \mathrm{mL}$ & $\mathrm{Bq} / \mathrm{mL}$ & $\mathrm{Bq} / \mathrm{mL}$ & $\mathrm{Bq} / \mathrm{mL}$ & $\mathrm{Bq} / \mathrm{mL}$ & $\mathrm{Bq} / \mathrm{mL}$ & $\mathrm{Bq} / \mathrm{mL}$ \\
\hline Co-60 & $b$ & $b$ & $b$ & $b$ & $b$ & $b$ & $b$ & $b$ & $b$ & $b$ \\
\hline Cs-137 & $7.40 \mathrm{E}+04$ & $1.00 \mathrm{E}+03$ & $8.50 \mathrm{E}+04$ & $1.00 \mathrm{E}+03$ & $8.30 \mathrm{E}+04$ & $1.00 \mathrm{E}+03$ & $8.60 \mathrm{E}+04$ & $1.00 \mathrm{E}+03$ & $7.90 \mathrm{E}+04$ & $1.00 \mathrm{E}+03$ \\
\hline Eu-152 & $b$ & $b$ & $b$ & $b$ & $b$ & $b$ & $b$ & $b$ & $b$ & $b$ \\
\hline Eu-154 & $b$ & $b$ & $b$ & $b$ & $b$ & $b$ & $b$ & $b$ & $b$ & $b$ \\
\hline Eu-155 & $b$ & $b$ & $b$ & $b$ & $b$ & $b$ & $b$ & $b$ & $b$ & $b$ \\
\hline Gross alpha & $b$ & $b$ & $b$ & $b$ & $b$ & $b$ & $b$ & $b$ & $4.00 \mathrm{E}+03$ & $2.00 \mathrm{E}+02$ \\
\hline Total activity & $b$ & $b$ & $b$ & $b$ & $b$ & $b$ & $b$ & $b$ & $1.40 \mathrm{E}+05$ & $1.00 \mathrm{E}+04$ \\
\hline
\end{tabular}

${ }^{a}$ Not applicable because result is below indicated detection limit.

${ }^{b}$ Either the measurement was not attempted or the specie was not detected. 
Table 4.6. Analysis of leachate solution: test at $3.0 \mathrm{~m} \mathrm{NaOH}, 60 \mathrm{EC}$, using sludge sample \#11 (results obtained at five run times)

\begin{tabular}{|c|c|c|c|c|c|c|c|c|c|c|}
\hline \multirow[b]{2}{*}{ Analyte } & \multicolumn{2}{|c|}{$\begin{array}{c}\text { Sample 11-1: } \\
1.073 \mathrm{~d} \\
\end{array}$} & \multicolumn{2}{|c|}{$\begin{array}{c}\text { Sample 11-2: } \\
2.042 \mathrm{~d} \\
\end{array}$} & \multicolumn{2}{|c|}{$\begin{array}{c}\text { Sample 11-3: } \\
4.083 \mathrm{~d} \\
\end{array}$} & \multicolumn{2}{|c|}{$\begin{array}{c}\text { Sample 11-4: } \\
6.743 \mathrm{~d} \\
\end{array}$} & \multicolumn{2}{|c|}{$\begin{array}{c}\text { Sample 11-5: } \\
10.000 \mathrm{~d}\end{array}$} \\
\hline & Result & Error & Result & Error & Result & Error & Result & Error & Result & Error \\
\hline Metals & $\mathrm{Fg} / \mathrm{mL}$ & $\mathrm{Fg} / \mathrm{mL}$ & $\mathrm{Fg} / \mathrm{mL}$ & $\mathrm{Fg} / \mathrm{mL}$ & $\mathrm{Fg} / \mathrm{mL}$ & $\mathrm{Fg} / \mathrm{mL}$ & $\mathrm{Fg} / \mathrm{mL}$ & $\mathrm{Fg} / \mathrm{mL}$ & $\mathrm{Fg} / \mathrm{mL}$ & $\mathrm{Fg} / \mathrm{mL}$ \\
\hline $\mathrm{Ag}$ & $<1.70 \mathrm{E}+00$ & $a$ & $<1.70 \mathrm{E}+00$ & $a$ & $<1.70 \mathrm{E}+00$ & $a$ & $<1.70 \mathrm{E}+00$ & $a$ & $<1.70 \mathrm{E}+00$ & $a$ \\
\hline $\mathrm{Al}$ & $1.29 \mathrm{E}+03$ & $1.30 \mathrm{E}+02$ & $2.75 \mathrm{E}+03$ & $2.80 \mathrm{E}+02$ & $4.27 \mathrm{E}+03$ & $4.30 \mathrm{E}+02$ & $5.13 \mathrm{E}+03$ & $5.10 \mathrm{E}+02$ & $7.19 \mathrm{E}+03$ & $7.20 \mathrm{E}+02$ \\
\hline $\mathrm{Ba}$ & $9.00 \mathrm{E}-01$ & $1.80 \mathrm{E}-01$ & $9.00 \mathrm{E}-01$ & $1.80 \mathrm{E}-01$ & $9.00 \mathrm{E}-01$ & $1.80 \mathrm{E}-01$ & $9.00 \mathrm{E}-01$ & $1.80 \mathrm{E}-01$ & $9.00 \mathrm{E}-01$ & $1.8 \mathrm{E}-01$ \\
\hline $\mathrm{Be}$ & $<1.00 \mathrm{E}-01$ & $a$ & $<1.00 \mathrm{E}-01$ & $a$ & $<1.00 \mathrm{E}-01$ & $a$ & $<1.00 \mathrm{E}-01$ & $a$ & $<1.00 \mathrm{E}-01$ & $a$ \\
\hline $\mathrm{Ca}$ & $1.81 \mathrm{E}+01$ & $1.80 \mathrm{E}+00$ & $1.20 \mathrm{E}+01$ & $2.40 \mathrm{E}+00$ & $1.14 \mathrm{E}+01$ & $2.30 \mathrm{E}+00$ & $2.37 \mathrm{E}+01$ & $2.4 \mathrm{E}+00$ & $2.99 \mathrm{E}+01$ & $3.00 \mathrm{E}+00$ \\
\hline $\mathrm{Cd}$ & $<1.62 \mathrm{E}+01$ & $a$ & $<1.62 \mathrm{E}+01$ & $a$ & $<1.62 \mathrm{E}+01$ & $a$ & $<1.62 \mathrm{E}+01$ & $a$ & $<1.62 \mathrm{E}+01$ & $a$ \\
\hline $\mathrm{Co}$ & $<1.00 \mathrm{E}+01$ & $a$ & $<1.00 \mathrm{E}+01$ & $a$ & $<1.00 \mathrm{E}+01$ & $a$ & $<1.00 \mathrm{E}+01$ & $a$ & $<1.00 \mathrm{E}+01$ & $a$ \\
\hline $\mathrm{Cr}$ & $<2.10 \mathrm{E}+00$ & $a$ & $<2.10 \mathrm{E}+00$ & $a$ & $<2.10 \mathrm{E}+00$ & $a$ & $<2.10 \mathrm{E}+00$ & $a$ & $<2.10 \mathrm{E}+00$ & $a$ \\
\hline $\mathrm{Cu}$ & $1.40 \mathrm{E}+00$ & $2.80 \mathrm{E}-01$ & $1.40 \mathrm{E}+00$ & $2.80 \mathrm{E}-01$ & $1.00 \mathrm{E}+00$ & $2.00 \mathrm{E}-01$ & $1.80 \mathrm{E}+00$ & $3.6 \mathrm{E}-01$ & $1.30 \mathrm{E}+00$ & $2.6 \mathrm{E}-01$ \\
\hline $\mathrm{Fe}$ & $<1.05 \mathrm{E}+01$ & $a$ & $<1.05 \mathrm{E}+01$ & $a$ & $<1.05 \mathrm{E}+01$ & $a$ & $<1.05 \mathrm{E}+01$ & $a$ & $<1.05 \mathrm{E}+01$ & $a$ \\
\hline $\mathrm{K}$ & $<2.50 \mathrm{E}+01$ & $a$ & $<2.50 \mathrm{E}+01$ & $a$ & $3.08 \mathrm{E}+01$ & $6.20 \mathrm{E}+00$ & $2.84 \mathrm{E}+01$ & $5.7 \mathrm{E}+00$ & $<2.50 \mathrm{E}+01$ & $a$ \\
\hline $\mathrm{Mg}$ & $<1.06 \mathrm{E}+01$ & $a$ & $<1.06 \mathrm{E}+01$ & $a$ & $<1.06 \mathrm{E}+01$ & $a$ & $<1.06 \mathrm{E}+01$ & $a$ & $<1.06 \mathrm{E}+01$ & $a$ \\
\hline $\mathrm{Mn}$ & $<2.00 \mathrm{E}-01$ & $a$ & $<2.00 \mathrm{E}-01$ & $a$ & $<2.00 \mathrm{E}-01$ & $a$ & $<2.00 \mathrm{E}-01$ & $a$ & $<2.00 \mathrm{E}-01$ & $a$ \\
\hline $\mathrm{Ni}$ & $<5.00 \mathrm{E}+00$ & $a$ & $<5.00 \mathrm{E}+00$ & $a$ & $<5.00 \mathrm{E}+00$ & $a$ & $<5.00 \mathrm{E}+00$ & $a$ & $<5.00 \mathrm{E}+00$ & $a$ \\
\hline $\mathrm{Sb}$ & $<6.20 \mathrm{E}+00$ & $a$ & $<6.20 \mathrm{E}+00$ & $a$ & $<6.20 \mathrm{E}+00$ & $a$ & $<6.20 \mathrm{E}+00$ & $a$ & $<6.20 \mathrm{E}+00$ & $a$ \\
\hline $\mathrm{Th}$ & $<2.51 \mathrm{E}+01$ & $a$ & $<2.51 \mathrm{E}+01$ & $a$ & $<2.51 \mathrm{E}+01$ & $a$ & $<2.51 \mathrm{E}+01$ & $a$ & $<2.51 \mathrm{E}+01$ & $a$ \\
\hline $\mathrm{U}$ & $<3.39 \mathrm{E}+01$ & $a$ & $<3.39 \mathrm{E}+01$ & $a$ & $<3.39 \mathrm{E}+01$ & $a$ & $<3.39 \mathrm{E}+01$ & $a$ & $<3.39 \mathrm{E}+01$ & $a$ \\
\hline $\mathrm{V}$ & $<6.20 \mathrm{E}+00$ & $a$ & $<6.20 \mathrm{E}+00$ & $a$ & $<6.20 \mathrm{E}+00$ & $a$ & $<6.20 \mathrm{E}+00$ & $a$ & $<6.20 \mathrm{E}+00$ & $a$ \\
\hline $\mathrm{Zn}$ & $7.72 \mathrm{E}+01$ & $1.54 \mathrm{E}+01$ & $<5.77 \mathrm{E}+01$ & $a$ & $<5.77 \mathrm{E}+01$ & $a$ & $<5.77 \mathrm{E}+01$ & $a$ & $<5.77 \mathrm{E}+01$ & $a$ \\
\hline Radionuclides & $\mathrm{Bq} / \mathrm{mL}$ & $\mathrm{Bq} / \mathrm{mL}$ & $\mathrm{Bq} / \mathrm{mL}$ & $\mathrm{Bq} / \mathrm{mL}$ & $\mathrm{Bq} / \mathrm{mL}$ & $\mathrm{Bq} / \mathrm{mL}$ & $\mathrm{Bq} / \mathrm{mL}$ & $\mathrm{Bq} / \mathrm{mL}$ & $\mathrm{Bq} / \mathrm{mL}$ & $\mathrm{Bq} / \mathrm{mL}$ \\
\hline Co-60 & $b$ & $b$ & $b$ & $b$ & $b$ & $b$ & $b$ & $b$ & $b$ & $b$ \\
\hline Cs-137 & $9.10 \mathrm{E}+04$ & $1.00 \mathrm{E}+03$ & $9.50 \mathrm{E}+04$ & $1.00 \mathrm{E}+03$ & $9.20 \mathrm{E}+04$ & $1.00 \mathrm{E}+03$ & $9.10 \mathrm{E}+04$ & $1.00 \mathrm{E}+03$ & $8.70 \mathrm{E}+04$ & $1.00 \mathrm{E}+03$ \\
\hline Eu-152 & $b$ & $b$ & $b$ & $b$ & $b$ & $b$ & $b$ & $b$ & $b$ & $b$ \\
\hline Eu-154 & $b$ & $b$ & $b$ & $b$ & $b$ & $b$ & $b$ & $b$ & $b$ & $b$ \\
\hline Eu-155 & $b$ & $b$ & $b$ & $b$ & $b$ & $b$ & $b$ & $b$ & $b$ & $b$ \\
\hline Gross alpha & $b$ & $b$ & $b$ & $b$ & $b$ & $b$ & $b$ & $b$ & $1.10 \mathrm{E}+04$ & $1.00 \mathrm{E}+03$ \\
\hline Total activity & $b$ & $b$ & $b$ & $b$ & $b$ & $b$ & $b$ & $b$ & $1.60 \mathrm{E}+05$ & $1.00 \mathrm{E}+04$ \\
\hline
\end{tabular}

${ }^{a}$ Not applicable because result is below indicated detection limit.

${ }^{b}$ Either the measurement was not attempted or the specie was not detected. 
Table 4.7. Analysis of leachate solution: test at $3.0 \mathrm{~m} \mathrm{NaOH}-0.1 \mathrm{~m}$ TEA, 60EC, using sludge sample \#09 (results obtained at five run times)

\begin{tabular}{|c|c|c|c|c|c|c|c|c|c|c|}
\hline \multirow[b]{2}{*}{ Analyte } & \multicolumn{2}{|c|}{$\begin{array}{c}\text { Sample 9-1: } \\
0.292 \mathrm{~d}\end{array}$} & \multicolumn{2}{|c|}{$\begin{array}{c}\text { Sample 9-2: } \\
1.000 \mathrm{~d}\end{array}$} & \multicolumn{2}{|c|}{$\begin{array}{c}\text { Sample 9-3: } \\
2.000 \mathrm{~d} \\
\end{array}$} & \multicolumn{2}{|c|}{$\begin{array}{c}\text { Sample 9-4: } \\
4.021 \mathrm{~d}\end{array}$} & \multicolumn{2}{|c|}{$\begin{array}{c}\text { Sample 9-5: } \\
11.021 \mathrm{~d} \\
\end{array}$} \\
\hline & Result & Error & Result & Error & Result & Error & Result & Error & Result & Error \\
\hline Metals & $\mathrm{Fg} / \mathrm{mL}$ & $\mathrm{Fg} / \mathrm{mL}$ & $\mathrm{Fg} / \mathrm{mL}$ & $\mathrm{Fg} / \mathrm{mL}$ & $\mathrm{Fg} / \mathrm{mL}$ & $\mathrm{Fg} / \mathrm{mL}$ & $\mathrm{Fg} / \mathrm{mL}$ & $\mathrm{Fg} / \mathrm{mL}$ & $\mathrm{Fg} / \mathrm{mL}$ & $\mathrm{Fg} / \mathrm{mL}$ \\
\hline $\mathrm{Ag}$ & $<1.05 \mathrm{E}+01$ & $a$ & $<1.15 \mathrm{E}+01$ & $a$ & $<1.20 \mathrm{E}+01$ & $a$ & $<1.15 \mathrm{E}+01$ & $a$ & $<1.15 \mathrm{E}+01$ & $a$ \\
\hline $\mathrm{Al}$ & $3.97 \mathrm{E}+02$ & $4.00 \mathrm{E}+01$ & $1.87 \mathrm{E}+03$ & $1.90 \mathrm{E}+02$ & $3.59 \mathrm{E}+03$ & $3.60 \mathrm{E}+02$ & $6.51 \mathrm{E}+03$ & $6.50 \mathrm{E}+02$ & $9.69 \mathrm{E}+03$ & $9.70 \mathrm{E}+02$ \\
\hline $\mathrm{Ba}$ & $<8.50 \mathrm{E}+00$ & $a$ & $<8.50 \mathrm{E}+00$ & $a$ & $<8.50 \mathrm{E}+01$ & $a$ & $<8.50 \mathrm{E}+00$ & $a$ & $<8.50 \mathrm{E}+00$ & $a$ \\
\hline $\mathrm{Be}$ & $<2.00 \mathrm{E}+00$ & $a$ & $<2.00 \mathrm{E}+00$ & $a$ & $<2.00 \mathrm{E}+00$ & $a$ & $<2.00 \mathrm{E}+00$ & $a$ & $<2.00 \mathrm{E}+00$ & $a$ \\
\hline $\mathrm{Ca}$ & $8.95 \mathrm{E}+01$ & $9.00 \mathrm{E}+00$ & $8.05 \mathrm{E}+01$ & $8.10 \mathrm{E}+00$ & $8.00 \mathrm{E}+01$ & $8.00 \mathrm{E}+00$ & $7.70 \mathrm{E}+01$ & $7.70 \mathrm{E}+00$ & $8.15 \mathrm{E}+01$ & $8.20 \mathrm{E}+00$ \\
\hline $\mathrm{Cd}$ & $<8.01 \mathrm{E}+01$ & $a$ & $<8.10 \mathrm{E}+01$ & $a$ & $<8.10 \mathrm{E}+01$ & $a$ & $<8.10 \mathrm{E}+01$ & $a$ & $<8.10 \mathrm{E}+01$ & $a$ \\
\hline Co & $<5.00 \mathrm{E}+01$ & $a$ & $<5.00 \mathrm{E}+01$ & $a$ & $<5.00 \mathrm{E}+01$ & $a$ & $<5.00 \mathrm{E}+01$ & $a$ & $<5.00 \mathrm{E}+01$ & $a$ \\
\hline $\mathrm{Cr}$ & $<1.25 \mathrm{E}+01$ & $a$ & $<1.45 \mathrm{E}+01$ & $a$ & $<1.65 \mathrm{E}+01$ & $a$ & $<1.55 \mathrm{E}+01$ & $a$ & $<1.50 \mathrm{E}+01$ & $a$ \\
\hline $\mathrm{Cu}$ & $9.00 \mathrm{E}+00$ & $1.80 \mathrm{E}+00$ & $1.45 \mathrm{E}+01$ & $2.90 \mathrm{E}+00$ & $1.45 \mathrm{E}+01$ & $2.90 \mathrm{E}+00$ & $1.50 \mathrm{E}+01$ & $3.00 \mathrm{E}+00$ & $1.65 \mathrm{E}+01$ & $3.30 \mathrm{E}+00$ \\
\hline $\mathrm{Fe}$ & $<5.25 \mathrm{E}+01$ & $a$ & $2.99 \mathrm{E}+02$ & $3.00 \mathrm{E}+01$ & $3.93 \mathrm{E}+02$ & $3.90 \mathrm{E}+01$ & $3.95 \mathrm{E}+02$ & $4.00 \mathrm{E}+01$ & $4.50 \mathrm{E}+02$ & $4.50 \mathrm{E}+01$ \\
\hline $\mathrm{K}$ & $<1.25 \mathrm{E}+02$ & $a$ & $<1.25 \mathrm{E}+02$ & $a$ & $<1.25 \mathrm{E}+02$ & $a$ & $<1.25 \mathrm{E}+02$ & $a$ & $<1.25 \mathrm{E}+02$ & $a$ \\
\hline $\mathrm{Mg}$ & $<5.30 \mathrm{E}+01$ & $a$ & $<5.30 \mathrm{E}+01$ & $a$ & $<5.30 \mathrm{E}+01$ & $a$ & $<5.30 \mathrm{E}+01$ & $a$ & $<5.30 \mathrm{E}+01$ & $a$ \\
\hline $\mathrm{Mn}$ & $1.25 \mathrm{E}+01$ & $1.30 \mathrm{E}+00$ & $1.15 \mathrm{E}+01$ & $1.20 \mathrm{E}+00$ & $1.15 \mathrm{E}+01$ & $1.20 \mathrm{E}+00$ & $1.15 \mathrm{E}+01$ & $1.20 \mathrm{E}+00$ & $1.30 \mathrm{E}+01$ & $a$ \\
\hline $\mathrm{Ni}$ & $<2.50 \mathrm{E}+01$ & $a$ & $<2.50 \mathrm{E}+01$ & $a$ & $<2.50 \mathrm{E}+01$ & $a$ & $<2.50 \mathrm{E}+01$ & $a$ & $<2.50 \mathrm{E}+01$ & $a$ \\
\hline $\mathrm{Sb}$ & $<3.10 \mathrm{E}+01$ & $a$ & $<3.10 \mathrm{E}+01$ & $a$ & $<3.10 \mathrm{E}+01$ & $a$ & $<3.10 \mathrm{E}+01$ & $a$ & $<3.10 \mathrm{E}+01$ & $a$ \\
\hline $\mathrm{Th}$ & $<1.26 \mathrm{E}+02$ & $a$ & $1.28 \mathrm{E}+02$ & $2.60 \mathrm{E}+01$ & $<1.26 \mathrm{E}+02$ & $a$ & $<1.26 \mathrm{E}+02$ & $a$ & $1.59 \mathrm{E}+02$ & $3.20 \mathrm{E}+01$ \\
\hline $\mathrm{U}$ & $<1.70 \mathrm{E}+02$ & $a$ & $<1.70 \mathrm{E}+02$ & $a$ & $<1.70 \mathrm{E}+02$ & $a$ & $<1.70 \mathrm{E}+02$ & $a$ & $<1.70 \mathrm{E}+02$ & $a$ \\
\hline $\mathrm{V}$ & $<3.10 \mathrm{E}+01$ & $a$ & $<3.10 \mathrm{E}+01$ & $a$ & $<3.10 \mathrm{E}+01$ & $a$ & $<3.10 \mathrm{E}+01$ & $a$ & $<3.10 \mathrm{E}+01$ & $a$ \\
\hline $\mathrm{Zn}$ & $<2.89 \mathrm{E}+02$ & $a$ & $<2.89 \mathrm{E}+02$ & $a$ & $<2.89 \mathrm{E}+02$ & $a$ & $<2.89 \mathrm{E}+02$ & $a$ & $<2.89 \mathrm{E}+02$ & $a$ \\
\hline Radionuclides & $\mathrm{Bq} / \mathrm{mL}$ & $\mathrm{Bq} / \mathrm{mL}$ & $\mathrm{Bq} / \mathrm{mL}$ & $\mathrm{Bq} / \mathrm{mL}$ & $\mathrm{Bq} / \mathrm{mL}$ & $\mathrm{Bq} / \mathrm{mL}$ & $\mathrm{Bq} / \mathrm{mL}$ & $\mathrm{Bq} / \mathrm{mL}$ & $\mathrm{Bq} / \mathrm{mL}$ & $\mathrm{Bq} / \mathrm{mL}$ \\
\hline Co-60 & $b$ & $b$ & $b$ & $b$ & $b$ & $b$ & $b$ & $b$ & $b$ & $b$ \\
\hline Cs-137 & $4.60 \mathrm{E}+04$ & $1.00 \mathrm{E}+03$ & $8.70 \mathrm{E}+04$ & $1.00 \mathrm{E}+03$ & $9.20 \mathrm{E}+04$ & $1.00 \mathrm{E}+03$ & $8.90 \mathrm{E}+04$ & $1.00 \mathrm{E}+03$ & $9.30 \mathrm{E}+04$ & $1.00 \mathrm{E}+03$ \\
\hline Eu-152 & $b$ & $b$ & $b$ & $b$ & $b$ & $b$ & $b$ & $b$ & $b$ & $b$ \\
\hline Eu-154 & $4.40 \mathrm{E}+01$ & $2.10 \mathrm{E}+01$ & $b$ & $b$ & $b$ & $b$ & $b$ & $b$ & $b$ & $b$ \\
\hline Eu-155 & $b$ & $b$ & $b$ & $b$ & $b$ & $b$ & $b$ & $b$ & $b$ & $b$ \\
\hline Gross alpha & $b$ & $b$ & $b$ & $b$ & $b$ & $b$ & $b$ & $b$ & $1.40 \mathrm{E}+03$ & $1.00 \mathrm{E}+02$ \\
\hline Total activity & $b$ & $b$ & $b$ & $b$ & $b$ & $b$ & $b$ & $b$ & $1.70 \mathrm{E}+05$ & $1.00 \mathrm{E}+04$ \\
\hline
\end{tabular}

${ }^{a}$ Not applicable because result is below indicated detection limit.

${ }^{b}$ Either the measurement was not attempted or the specie was not detected. 
Table 4.8. Analysis of leachate solution: test at 3.0 $\mathrm{m}$ NaOH-3.0 $\mathrm{m}$ TEA, 60EC, using sludge sample \#08 (results obtained at five run times)

\begin{tabular}{|c|c|c|c|c|c|c|c|c|c|c|}
\hline \multirow[b]{2}{*}{ Analyte } & \multicolumn{2}{|c|}{$\begin{array}{c}\text { Sample 8-1: } \\
0.292 \mathrm{~d} \\
\end{array}$} & \multicolumn{2}{|c|}{$\begin{array}{c}\text { Sample 8-2: } \\
1.000 \mathrm{~d} \\
\end{array}$} & \multicolumn{2}{|c|}{$\begin{array}{c}\text { Sample 8-3: } \\
2.000 \mathrm{~d} \\
\end{array}$} & \multicolumn{2}{|c|}{$\begin{array}{c}\text { Sample 8-4: } \\
4.021 \mathrm{~d} \\
\end{array}$} & \multicolumn{2}{|c|}{$\begin{array}{c}\text { Sample 8-5: } \\
11.021 \mathrm{~d} \\
\end{array}$} \\
\hline & Result & Error & Result & Error & Result & Error & Result & Error & Result & Error \\
\hline Metals & $\mathrm{Fg} / \mathrm{mL}$ & $\mathrm{Fg} / \mathrm{mL}$ & $\mathrm{Fg} / \mathrm{mL}$ & $\mathrm{Fg} / \mathrm{mL}$ & $\mathrm{Fg} / \mathrm{mL}$ & $\mathrm{Fg} / \mathrm{mL}$ & $\mathrm{Fg} / \mathrm{mL}$ & $\mathrm{Fg} / \mathrm{mL}$ & $\mathrm{Fg} / \mathrm{mL}$ & $\mathrm{Fg} / \mathrm{mL}$ \\
\hline $\mathrm{Ag}$ & $<1.25 \mathrm{E}+01$ & $a$ & $<1.15 \mathrm{E}+01$ & $a$ & $<1.15 \mathrm{E}+01$ & $a$ & $<1.00 \mathrm{E}+01$ & $a$ & $<1.15 \mathrm{E}+01$ & $a$ \\
\hline $\mathrm{Al}$ & $1.72 \mathrm{E}+02$ & $1.70 \mathrm{E}+01$ & $1.48 \mathrm{E}+03$ & $1.40 \mathrm{E}+02$ & $3.33 \mathrm{E}+03$ & $3.30 \mathrm{E}+02$ & $7.15 \mathrm{E}+03$ & $7.20 \mathrm{E}+02$ & $1.78 \mathrm{E}+04$ & $1.80 \mathrm{E}+04$ \\
\hline $\mathrm{Ba}$ & $<8.50 \mathrm{E}+00$ & $a$ & $<8.50 \mathrm{E}+00$ & $a$ & $<8.00 \mathrm{E}+00$ & $a$ & $<8.00 \mathrm{E}+00$ & $a$ & $<8.00 \mathrm{E}+00$ & $a$ \\
\hline $\mathrm{Be}$ & $<2.00 \mathrm{E}+00$ & $a$ & $<2.00 \mathrm{E}+00$ & $a$ & $<2.00 \mathrm{E}+00$ & $a$ & $<2.00 \mathrm{E}+00$ & $a$ & $<2.00 \mathrm{E}+00$ & $a$ \\
\hline $\mathrm{Ca}$ & $1.05 \mathrm{E}+02$ & $1.10 \mathrm{E}+01$ & $8.55 \mathrm{E}+01$ & $8.50 \mathrm{E}+00$ & $9.10 \mathrm{E}+01$ & $9.10 \mathrm{E}+00$ & $9.00 \mathrm{E}+01$ & $9.00 \mathrm{E}+00$ & $1.02 \mathrm{E}+02$ & $1.00 \mathrm{E}+01$ \\
\hline $\mathrm{Cd}$ & $<8.10 \mathrm{E}+01$ & $a$ & $<8.10 \mathrm{E}+01$ & $a$ & $<8.10 \mathrm{E}+01$ & $a$ & $<8.10 \mathrm{E}+01$ & $a$ & $<8.10 \mathrm{E}+01$ & $a$ \\
\hline $\mathrm{Co}$ & $<5.00 \mathrm{E}+01$ & $a$ & $<5.00 \mathrm{E}+01$ & $a$ & $<5.00 \mathrm{E}+01$ & $a$ & $<5.00 \mathrm{E}+01$ & $a$ & $<5.00 \mathrm{E}+01$ & $a$ \\
\hline $\mathrm{Cr}$ & $<1.65 \mathrm{E}+01$ & $a$ & $<1.85 \mathrm{E}+01$ & $a$ & $<2.00 \mathrm{E}+01$ & $a$ & $<1.75 \mathrm{E}+01$ & $a$ & $<1.15 \mathrm{E}+01$ & $a$ \\
\hline $\mathrm{Cu}$ & $9.00 \mathrm{E}+00$ & $1.8 \mathrm{E}+00$ & $1.45 \mathrm{E}+01$ & $2.90 \mathrm{E}+00$ & $1.95 \mathrm{E}+01$ & $2.00 \mathrm{E}+00$ & $2.10 \mathrm{E}+01$ & $2.10 \mathrm{E}+00$ & $2.65 \mathrm{E}+01$ & $2.70 \mathrm{E}+00$ \\
\hline $\mathrm{Fe}$ & $8.25 \mathrm{E}+01$ & $1.65 \mathrm{E}+01$ & $3.08 \mathrm{E}+02$ & $3.10 \mathrm{E}+01$ & $5.60 \mathrm{E}+02$ & $5.60 \mathrm{E}+01$ & $6.95 \mathrm{E}+02$ & $7.00 \mathrm{E}+01$ & $1.09 \mathrm{E}+03$ & $1.10 \mathrm{E}+02$ \\
\hline $\mathrm{K}$ & $<1.25 \mathrm{E}+02$ & $a$ & $<1.25 \mathrm{E}+02$ & $a$ & $<1.25 \mathrm{E}+02$ & $a$ & $<1.25 \mathrm{E}+02$ & $a$ & $<1.25 \mathrm{E}+02$ & $a$ \\
\hline $\mathrm{Mg}$ & $<5.30 \mathrm{E}+01$ & $a$ & $<5.30 \mathrm{E}+01$ & $a$ & $<5.30 \mathrm{E}+01$ & $a$ & $<5.30 \mathrm{E}+01$ & $a$ & $<5.30 \mathrm{E}+01$ & $a$ \\
\hline $\mathrm{Mn}$ & $5.10 \mathrm{E}+01$ & $5.10 \mathrm{E}+00$ & $1.81 \mathrm{E}+02$ & $1.80 \mathrm{E}+01$ & $3.20 \mathrm{E}+02$ & $3.20 \mathrm{E}+01$ & $3.93 \mathrm{E}+02$ & $3.90 \mathrm{E}+01$ & $2.62 \mathrm{E}+02$ & $2.60 \mathrm{E}+01$ \\
\hline $\mathrm{Ni}$ & $<2.50 \mathrm{E}+01$ & $a$ & $2.70 \mathrm{E}+01$ & $5.40 \mathrm{E}+00$ & $4.30 \mathrm{E}+01$ & $8.60 \mathrm{E}+00$ & $6.40 \mathrm{E}+01$ & $1.28 \mathrm{E}+01$ & $5.95 \mathrm{E}+01$ & $1.19 \mathrm{E}+01$ \\
\hline $\mathrm{Sb}$ & $<3.10 \mathrm{E}+01$ & $a$ & $<3.10 \mathrm{E}+01$ & $a$ & $<3.10 \mathrm{E}+01$ & $a$ & $<3.10 \mathrm{E}+01$ & $a$ & $<3.10 \mathrm{E}+01$ & $a$ \\
\hline Th & $<1.26 \mathrm{E}+02$ & $a$ & $<1.26 \mathrm{E}+02$ & $a$ & $<1.26 \mathrm{E}+02$ & $a$ & $<1.26 \mathrm{E}+02$ & $a$ & $<1.26 \mathrm{E}+02$ & $a$ \\
\hline $\mathrm{U}$ & $<1.70 \mathrm{E}+02$ & $a$ & $<1.70 \mathrm{E}+02$ & $a$ & $<1.70 \mathrm{E}+02$ & $a$ & $<1.70 \mathrm{E}+02$ & $a$ & $<1.70 \mathrm{E}+02$ & $a$ \\
\hline V & $<3.10 \mathrm{E}+01$ & $a$ & $<3.10 \mathrm{E}+01$ & $a$ & $<3.10 \mathrm{E}+01$ & $a$ & $<3.10 \mathrm{E}+01$ & $a$ & $<3.10 \mathrm{E}+01$ & $a$ \\
\hline $\mathrm{Zn}$ & $<2.89 \mathrm{E}+02$ & $a$ & $<2.89 \mathrm{E}+02$ & $a$ & $<2.89 \mathrm{E}+02$ & $a$ & $<2.89 \mathrm{E}+02$ & $a$ & $<2.89 \mathrm{E}+02$ & $a$ \\
\hline Radionuclides & $\mathrm{Bq} / \mathrm{mL}$ & $\mathrm{Bq} / \mathrm{mL}$ & $\mathrm{Bq} / \mathrm{mL}$ & $\mathrm{Bq} / \mathrm{mL}$ & $\mathrm{Bq} / \mathrm{mL}$ & $\mathrm{Bq} / \mathrm{mL}$ & $\mathrm{Bq} / \mathrm{mL}$ & $\mathrm{Bq} / \mathrm{mL}$ & $\mathrm{Bq} / \mathrm{mL}$ & $\mathrm{Bq} / \mathrm{mL}$ \\
\hline Co-60 & $4.90 \mathrm{E}+01$ & $-1.60 \mathrm{E}+01$ & $2.70 \mathrm{E}+02$ & $4.00 \mathrm{E}+01$ & $6.20 \mathrm{E}+02$ & $5.00 \mathrm{E}+01$ & $8.90 \mathrm{E}+02$ & $6.00 \mathrm{E}+01$ & $1.20 \mathrm{E}+03$ & $1.00 \mathrm{E}+02$ \\
\hline Cs-137 & $2.70 \mathrm{E}+04$ & $1.00 \mathrm{E}+03$ & $9.10 \mathrm{E}+04$ & $1.00 \mathrm{E}+03$ & $1.00 \mathrm{E}+05$ & $1.00 \mathrm{E}+04$ & $1.00 \mathrm{E}+05$ & $1.00 \mathrm{E}+04$ & $1.00 \mathrm{E}+05$ & $1.00 \mathrm{E}+04$ \\
\hline Eu-152 & $b$ & $b$ & $b$ & $b$ & $b$ & $b$ & $b$ & $b$ & $b$ & $b$ \\
\hline Eu-154 & $6.50 \mathrm{E}+02$ & $8.00 \mathrm{E}+01$ & $6.50 \mathrm{E}+02$ & $9.00 \mathrm{E}+01$ & $4.80 \mathrm{E}+02$ & $8.00 \mathrm{E}+01$ & $4.70 \mathrm{E}+02$ & $9.00 \mathrm{E}+01$ & $5.00 \mathrm{E}+02$ & $8.00 \mathrm{E}+01$ \\
\hline Eu-155 & $1.60 \mathrm{E}+02$ & $1.10 \mathrm{E}+02$ & $b$ & $b$ & $2.80 \mathrm{E}+02$ & $1.80 \mathrm{E}+02$ & $b$ & $b$ & $b$ & $b$ \\
\hline Gross alpha & $b$ & $b$ & $b$ & $b$ & $b$ & $b$ & $b$ & $b$ & $5.30 \mathrm{E}+04$ & $1.00 \mathrm{E}+03$ \\
\hline Total activity & $b$ & $b$ & $b$ & $b$ & $b$ & $b$ & $b$ & $b$ & $1.60 \mathrm{E}+06$ & $1.00 \mathrm{E}+05$ \\
\hline
\end{tabular}

${ }^{a}$ Not applicable because result is below indicated detection limit.

${ }^{b}$ Either the measurement was not attempted or the specie was not detected. 
Table 4.9. Analysis of leachate solution: test at $0.1 \mathrm{~m} \mathrm{NaOH}-2.9 \mathrm{~m} \mathrm{NaNO}, 60 \mathrm{EC}$, using sludge sample \#06 (results obtained at five run times)

\begin{tabular}{|c|c|c|c|c|c|c|c|c|c|c|}
\hline \multirow[b]{2}{*}{ Analyte } & \multicolumn{2}{|c|}{$\begin{array}{c}\text { Sample 6-1: } \\
0.292 \mathrm{~d} \\
\end{array}$} & \multicolumn{2}{|c|}{$\begin{array}{c}\text { Sample 6-2: } \\
1.000 \mathrm{~d} \\
\end{array}$} & \multicolumn{2}{|c|}{$\begin{array}{c}\text { Sample 6-3: } \\
2.000 \mathrm{~d} \\
\end{array}$} & \multicolumn{2}{|c|}{$\begin{array}{c}\text { Sample 6-4: } \\
5.000 \mathrm{~d} \\
\end{array}$} & \multicolumn{2}{|c|}{$\begin{array}{c}\text { Sample 6-5: } \\
11.917 \mathrm{~d} \\
\end{array}$} \\
\hline & Result & Error & Result & Error & Result & Error & Result & Error & Result & Error \\
\hline Metals & $\mathrm{Fg} / \mathrm{mL}$ & $\mathrm{Fg} / \mathrm{mL}$ & $\mathrm{Fg} / \mathrm{mL}$ & $\mathrm{Fg} / \mathrm{mL}$ & $\mathrm{Fg} / \mathrm{mL}$ & $\mathrm{Fg} / \mathrm{mL}$ & $\mathrm{Fg} / \mathrm{mL}$ & $\mathrm{Fg} / \mathrm{mL}$ & $\mathrm{Fg} / \mathrm{mL}$ & $\mathrm{Fg} / \mathrm{mL}$ \\
\hline $\mathrm{Ag}$ & $<1.70 \mathrm{E}+00$ & $a$ & $<1.70 \mathrm{E}+00$ & $a$ & $<1.70 \mathrm{E}+00$ & $a$ & $<1.70 \mathrm{E}+00$ & $a$ & $<1.70 \mathrm{E}+00$ & $a$ \\
\hline $\mathrm{Al}$ & $2.22 \mathrm{E}+02$ & $2.20 \mathrm{E}+01$ & $3.37 \mathrm{E}+02$ & $3.40 \mathrm{E}+01$ & $3.65 \mathrm{E}+02$ & $3.70 \mathrm{E}+01$ & $3.69 \mathrm{E}+02$ & $3.70 \mathrm{E}+01$ & $3.70 \mathrm{E}+02$ & $3.70 \mathrm{E}+01$ \\
\hline $\mathrm{Ba}$ & $<2.00 \mathrm{E}-01$ & $a$ & $<2.00 \mathrm{E}-01$ & $a$ & $<2.00 \mathrm{E}-01$ & $a$ & $<2.00 \mathrm{E}-01$ & $a$ & $<2.00 \mathrm{E}-01$ & $a$ \\
\hline $\mathrm{Be}$ & $<1.00 \mathrm{E}-01$ & $a$ & $<1.00 \mathrm{E}-01$ & $a$ & $<1.00 \mathrm{E}-01$ & $a$ & $<1.00 \mathrm{E}-01$ & $a$ & $<1.00 \mathrm{E}-01$ & $a$ \\
\hline $\mathrm{Ca}$ & $<3.00 \mathrm{E}+00$ & $a$ & $<3.00 \mathrm{E}+00$ & $a$ & $<3.00 \mathrm{E}+00$ & $a$ & $<3.00 \mathrm{E}+00$ & $a$ & $<3.00 \mathrm{E}+00$ & $a$ \\
\hline $\mathrm{Cd}$ & $<1.62 \mathrm{E}+01$ & $a$ & $<1.62 \mathrm{E}+01$ & $a$ & $<1.62 \mathrm{E}+01$ & $a$ & $<1.62 \mathrm{E}+01$ & $a$ & $<1.62 \mathrm{E}+01$ & $a$ \\
\hline $\mathrm{Co}$ & $<1.00 \mathrm{E}+01$ & $a$ & $<1.00 \mathrm{E}+01$ & $a$ & $<1.00 \mathrm{E}+01$ & $a$ & $<1.00 \mathrm{E}+01$ & $a$ & $<1.00 \mathrm{E}+01$ & $a$ \\
\hline $\mathrm{Cr}$ & $<2.10 \mathrm{E}+00$ & $a$ & $<2.10 \mathrm{E}+00$ & $a$ & $<2.10 \mathrm{E}+00$ & $a$ & $<2.10 \mathrm{E}+00$ & $a$ & $<2.10 \mathrm{E}+00$ & $a$ \\
\hline $\mathrm{Cu}$ & $<7.00 \mathrm{E}-01$ & $a$ & $<7.00 \mathrm{E}-01$ & $a$ & $<7.00 \mathrm{E}-01$ & $a$ & $<7.00 \mathrm{E}-01$ & $a$ & $<7.00 \mathrm{E}-01$ & $a$ \\
\hline $\mathrm{Fe}$ & $1.30 \mathrm{E}+01$ & $2.60 \mathrm{E}+00$ & $<1.05 \mathrm{E}+01$ & $a$ & $<1.05 \mathrm{E}+01$ & $a$ & $<1.05 \mathrm{E}+01$ & $a$ & $<1.05 \mathrm{E}+01$ & $a$ \\
\hline $\mathrm{K}$ & $<2.50 \mathrm{E}+01$ & $a$ & $<2.50 \mathrm{E}+01$ & $a$ & $<2.50 \mathrm{E}+01$ & $a$ & $<2.50 \mathrm{E}+01$ & $a$ & $<2.50 \mathrm{E}+01$ & $a$ \\
\hline $\mathrm{Mg}$ & $<1.06 \mathrm{E}+01$ & $a$ & $<1.06 \mathrm{E}+01$ & $a$ & $<1.06 \mathrm{E}+01$ & $a$ & $<1.06 \mathrm{E}+01$ & $a$ & $<1.06 \mathrm{E}+01$ & $a$ \\
\hline $\mathrm{Mn}$ & $<2.00 \mathrm{E}-01$ & $a$ & $<2.00 \mathrm{E}-01$ & $a$ & $<2.00 \mathrm{E}-01$ & $a$ & $<2.00 \mathrm{E}-01$ & $a$ & $<2.00 \mathrm{E}-01$ & $a$ \\
\hline $\mathrm{Ni}$ & $<5.00 \mathrm{E}+00$ & $a$ & $<5.00 \mathrm{E}+00$ & $a$ & $<5.00 \mathrm{E}+00$ & $a$ & $<5.00 \mathrm{E}+00$ & $a$ & $<5.00 \mathrm{E}+00$ & $a$ \\
\hline $\mathrm{Sb}$ & $<5.79 \mathrm{E}+01$ & $a$ & $<2.84 \mathrm{E}+01$ & $a$ & $<9.60 \mathrm{E}+01$ & $a$ & $<6.83 \mathrm{E}+01$ & $a$ & $<2.49 \mathrm{E}+01$ & $a$ \\
\hline $\mathrm{Th}$ & $<2.51 \mathrm{E}+01$ & $a$ & $<2.51 \mathrm{E}+01$ & $a$ & $<2.51 \mathrm{E}+01$ & $a$ & $<2.51 \mathrm{E}+01$ & $a$ & $<2.51 \mathrm{E}+01$ & $a$ \\
\hline $\mathrm{U}$ & $<3.39 \mathrm{E}+01$ & $a$ & $<3.39 \mathrm{E}+01$ & $a$ & $<3.39 \mathrm{E}+01$ & $a$ & $<3.39 \mathrm{E}+01$ & $a$ & $<3.39 \mathrm{E}+01$ & $a$ \\
\hline $\mathrm{V}$ & $<6.20 \mathrm{E}+00$ & $a$ & $<6.20 \mathrm{E}+00$ & $a$ & $<6.20 \mathrm{E}+00$ & $a$ & $<6.20 \mathrm{E}+00$ & $a$ & $<6.20 \mathrm{E}+00$ & $a$ \\
\hline $\mathrm{Zn}$ & $<5.77 \mathrm{E}+01$ & $a$ & $<5.77 \mathrm{E}+01$ & $a$ & $<5.77 \mathrm{E}+01$ & $a$ & $<5.77 \mathrm{E}+01$ & $a$ & $<5.77 \mathrm{E}+01$ & $a$ \\
\hline Radionuclides & $\mathrm{Bq} / \mathrm{mL}$ & $\mathrm{Bq} / \mathrm{mL}$ & $\mathrm{Bq} / \mathrm{mL}$ & $\mathrm{Bq} / \mathrm{mL}$ & $\mathrm{Bq} / \mathrm{mL}$ & $\mathrm{Bq} / \mathrm{mL}$ & $\mathrm{Bq} / \mathrm{mL}$ & $\mathrm{Bq} / \mathrm{mL}$ & $\mathrm{Bq} / \mathrm{mL}$ & $\mathrm{Bq} / \mathrm{mL}$ \\
\hline Co-60 & $b$ & $b$ & $b$ & $b$ & $b$ & $b$ & $b$ & $b$ & $b$ & $b$ \\
\hline Cs-137 & $6.90 \mathrm{E}+04$ & $1.00 \mathrm{E}+03$ & $7.00 \mathrm{E}+04$ & $1.00 \mathrm{E}+03$ & $6.90 \mathrm{E}+04$ & $1.00 \mathrm{E}+03$ & $7.20 \mathrm{E}+04$ & $1.00 \mathrm{E}+03$ & $7.10 \mathrm{E}+04$ & $1.00 \mathrm{E}+03$ \\
\hline Eu-152 & $b$ & $b$ & $b$ & $b$ & $b$ & $b$ & $b$ & $b$ & $b$ & $b$ \\
\hline Eu-154 & $b$ & $b$ & $b$ & $b$ & $b$ & $b$ & $b$ & $b$ & $b$ & $b$ \\
\hline Eu-155 & $b$ & $b$ & $b$ & $b$ & $b$ & $b$ & $b$ & $b$ & $b$ & $b$ \\
\hline Gross alpha & $b$ & $b$ & $b$ & $b$ & $b$ & $b$ & $b$ & $b$ & $1.10 \mathrm{E}+02$ & $2.00 \mathrm{E}+01$ \\
\hline Total activity & $b$ & $b$ & $b$ & $b$ & $b$ & $b$ & $b$ & $b$ & $1.00 \mathrm{E}+05$ & $1.00 \mathrm{E}+04$ \\
\hline
\end{tabular}

${ }^{a}$ Not applicable because result is below indicated detection limit.

${ }^{b}$ Either the measurement was not attempted or the specie was not detected. 
Table 4.10. Analysis of leachate solution: test at $0.1 \mathrm{~m} \mathrm{NaOH}-2.9 \mathrm{~m} \mathrm{NaNO}_{3}-0.1 \mathrm{~m}$ TEA, 60EC, using sludge sample \#07 (results obtained at five run times)

\begin{tabular}{|c|c|c|c|c|c|c|c|c|c|c|}
\hline \multirow[b]{2}{*}{ Analyte } & \multicolumn{2}{|c|}{$\begin{array}{c}\text { Sample 7-1: } \\
0.292 \mathrm{~d}\end{array}$} & \multicolumn{2}{|c|}{$\begin{array}{c}\text { Sample 7-2: } \\
1.000 \mathrm{~d} \\
\end{array}$} & \multicolumn{2}{|c|}{$\begin{array}{c}\text { Sample 7-3: } \\
2.000 \mathrm{~d}\end{array}$} & \multicolumn{2}{|c|}{$\begin{array}{c}\text { Sample 7-4: } \\
5.000 \mathrm{~d} \\
\end{array}$} & \multicolumn{2}{|c|}{$\begin{array}{c}\text { Sample 7-5: } \\
11.917 \mathrm{~d} \\
\end{array}$} \\
\hline & Result & Error & Result & Error & Result & Error & Result & Error & Result & Error \\
\hline Metals & $\mathrm{Fg} / \mathrm{mL}$ & $\mathrm{Fg} / \mathrm{mL}$ & $\mathrm{Fg} / \mathrm{mL}$ & $\mathrm{Fg} / \mathrm{mL}$ & $\mathrm{Fg} / \mathrm{mL}$ & $\mathrm{Fg} / \mathrm{mL}$ & $\mathrm{Fg} / \mathrm{mL}$ & $\mathrm{Fg} / \mathrm{mL}$ & $\mathrm{Fg} / \mathrm{mL}$ & $\mathrm{Fg} / \mathrm{mL}$ \\
\hline $\mathrm{Ag}$ & $<1.70 \mathrm{E}+00$ & $a$ & $<1.70 \mathrm{E}+00$ & $a$ & $<1.70 \mathrm{E}+00$ & $a$ & $<1.70 \mathrm{E}+00$ & $a$ & $<1.70 \mathrm{E}+00$ & $a$ \\
\hline $\mathrm{Al}$ & $3.76 \mathrm{E}+02$ & $3.80 \mathrm{E}+01$ & $7.62 \mathrm{E}+02$ & $7.60 \mathrm{E}+01$ & $7.84 \mathrm{E}+02$ & $7.80 \mathrm{E}+01$ & $7.40 \mathrm{E}+02$ & $7.40 \mathrm{E}+01$ & $<4.95 \mathrm{E}+00$ & $a$ \\
\hline $\mathrm{Ba}$ & $<2.00 \mathrm{E}-01$ & $a$ & $<2.00 \mathrm{E}-01$ & $a$ & $<2.00 \mathrm{E}-01$ & $a$ & $<2.00 \mathrm{E}-01$ & $a$ & $<2.00 \mathrm{E}-01$ & $a$ \\
\hline $\mathrm{Be}$ & $<1.00 \mathrm{E}-01$ & $a$ & $<1.00 \mathrm{E}-01$ & $a$ & $<1.00 \mathrm{E}-01$ & $a$ & $<1.00 \mathrm{E}-01$ & $a$ & $<1.00 \mathrm{E}-01$ & $a$ \\
\hline $\mathrm{Ca}$ & $<3.00 \mathrm{E}+00$ & $a$ & $<3.00 \mathrm{E}+00$ & $a$ & $3.60 \mathrm{E}+00$ & $7.20 \mathrm{E}-01$ & $<3.00 \mathrm{E}+00$ & $a$ & $<3.00 \mathrm{E}+00$ & $a$ \\
\hline $\mathrm{Cd}$ & $<1.62 \mathrm{E}+01$ & $a$ & $<1.62 \mathrm{E}+01$ & $a$ & $<1.62 \mathrm{E}+01$ & $a$ & $<1.62 \mathrm{E}+01$ & $a$ & $<1.62 \mathrm{E}+01$ & $a$ \\
\hline $\mathrm{Co}$ & $<1.00 \mathrm{E}+01$ & $a$ & $<1.00 \mathrm{E}+01$ & $a$ & $<1.00 \mathrm{E}+01$ & $a$ & $<1.00 \mathrm{E}+01$ & $a$ & $<1.00 \mathrm{E}+01$ & $a$ \\
\hline $\mathrm{Cr}$ & $<2.10 \mathrm{E}+00$ & $a$ & $<2.10 \mathrm{E}+00$ & $a$ & $<2.10 \mathrm{E}+00$ & $a$ & $<2.10 \mathrm{E}+00$ & $a$ & $<2.10 \mathrm{E}+00$ & $a$ \\
\hline $\mathrm{Cu}$ & $<7.00 \mathrm{E}-01$ & $a$ & $<7.00 \mathrm{E}-01$ & $a$ & $<7.00 \mathrm{E}-01$ & $a$ & $<7.00 \mathrm{E}-01$ & $a$ & $<7.00 \mathrm{E}-01$ & $a$ \\
\hline $\mathrm{Fe}$ & $5.08 \mathrm{E}+01$ & $1.02 \mathrm{E}+01$ & $8.64 \mathrm{E}+01$ & $8.60 \mathrm{E}+00$ & $1.00 \mathrm{E}+02$ & $1.00 \mathrm{E}+01$ & $1.21 \mathrm{E}+02$ & $1.20 \mathrm{E}+01$ & $<1.05 \mathrm{E}+01$ & $a$ \\
\hline $\mathrm{K}$ & $<2.50 \mathrm{E}+01$ & $a$ & $<2.50 \mathrm{E}+01$ & $a$ & $<2.50 \mathrm{E}+01$ & $a$ & $<2.50 \mathrm{E}+01$ & $a$ & $<2.50 \mathrm{E}+01$ & $a$ \\
\hline $\mathrm{Mg}$ & $<1.06 \mathrm{E}+01$ & $a$ & $<1.06 \mathrm{E}+01$ & $a$ & $<1.06 \mathrm{E}+01$ & $a$ & $<1.06 \mathrm{E}+01$ & $a$ & $<1.06 \mathrm{E}+01$ & $a$ \\
\hline $\mathrm{Mn}$ & $<2.00 \mathrm{E}-01$ & $a$ & $<2.00 \mathrm{E}-01$ & $a$ & $<2.00 \mathrm{E}-01$ & $a$ & $<2.00 \mathrm{E}-01$ & $a$ & $<2.00 \mathrm{E}-01$ & $a$ \\
\hline $\mathrm{Ni}$ & $<5.00 \mathrm{E}+00$ & $a$ & $<5.00 \mathrm{E}+00$ & $a$ & $<5.00 \mathrm{E}+00$ & $a$ & $<5.00 \mathrm{E}+00$ & $a$ & $<5.00 \mathrm{E}+00$ & $a$ \\
\hline $\mathrm{Sb}$ & $<7.43 \mathrm{E}+01$ & $a$ & $<3.79 \mathrm{E}+01$ & $a$ & $<6.57 \mathrm{E}+01$ & $a$ & $<7.09 \mathrm{E}+01$ & $a$ & $<9.60 \mathrm{E}+01$ & $a$ \\
\hline $\mathrm{Th}$ & $<2.51 \mathrm{E}+01$ & $a$ & $<2.51 \mathrm{E}+01$ & $a$ & $<2.51 \mathrm{E}+01$ & $a$ & $<2.51 \mathrm{E}+01$ & $a$ & $<2.51 \mathrm{E}+01$ & $a$ \\
\hline $\mathrm{U}$ & $<3.39 \mathrm{E}+01$ & $a$ & $<3.39 \mathrm{E}+01$ & $a$ & $<3.39 \mathrm{E}+01$ & $a$ & $<3.39 \mathrm{E}+01$ & $a$ & $<3.39 \mathrm{E}+01$ & $a$ \\
\hline $\mathrm{V}$ & $<6.20 \mathrm{E}+00$ & $a$ & $<6.20 \mathrm{E}+00$ & $a$ & $<6.20 \mathrm{E}+00$ & $a$ & $<6.20 \mathrm{E}+00$ & $a$ & $<6.20 \mathrm{E}+00$ & $a$ \\
\hline $\mathrm{Zn}$ & $<5.77 \mathrm{E}+01$ & $a$ & $<5.77 \mathrm{E}+01$ & $a$ & $1.08 \mathrm{E}+02$ & $2.20 \mathrm{E}+01$ & $<5.77 \mathrm{E}+01$ & $a$ & $<5.77 \mathrm{E}+01$ & $a$ \\
\hline Radionuclides & $\mathrm{Bq} / \mathrm{mL}$ & $\mathrm{Bq} / \mathrm{mL}$ & $\mathrm{Bq} / \mathrm{mL}$ & $\mathrm{Bq} / \mathrm{mL}$ & $\mathrm{Bq} / \mathrm{mL}$ & $\mathrm{Bq} / \mathrm{mL}$ & $\mathrm{Bq} / \mathrm{mL}$ & $\mathrm{Bq} / \mathrm{mL}$ & $\mathrm{Bq} / \mathrm{mL}$ & $\mathrm{Bq} / \mathrm{mL}$ \\
\hline Co-60 & $b$ & $b$ & $2.10 \mathrm{E}+01$ & $9.00 \mathrm{E}+00$ & $2.20 \mathrm{E}+01$ & $1.20 \mathrm{E}+01$ & $3.30 \mathrm{E}+01$ & $1.40 \mathrm{E}+01$ & $5.10 \mathrm{E}+01$ & $1.30 \mathrm{E}+01$ \\
\hline Cs-137 & $6.80 \mathrm{E}+04$ & $1.00 \mathrm{E}+03$ & $7.00 \mathrm{E}+04$ & $1.00 \mathrm{E}+03$ & $6.90 \mathrm{E}+04$ & $1.00 \mathrm{E}+03$ & $6.80 \mathrm{E}+04$ & $1.00 \mathrm{E}+03$ & $7.20 \mathrm{E}+04$ & $1.00 \mathrm{E}+03$ \\
\hline Eu-152 & $b$ & $b$ & $b$ & $b$ & $b$ & $b$ & $b$ & $b$ & $b$ & $b$ \\
\hline Eu-154 & $b$ & $b$ & $b$ & $b$ & $b$ & $b$ & $b$ & $b$ & $b$ & $b$ \\
\hline Eu-155 & $b$ & $b$ & $b$ & $b$ & $b$ & $b$ & $b$ & $b$ & $b$ & $b$ \\
\hline Gross alpha & $b$ & $b$ & $b$ & $b$ & $b$ & $b$ & $b$ & $b$ & $1.20 \mathrm{E}+01$ & $6.00 \mathrm{E}+00$ \\
\hline Total activity & $b$ & $b$ & $b$ & $b$ & $b$ & $b$ & $b$ & $b$ & $1.30 \mathrm{E}+05$ & $1.00 \mathrm{E}+04$ \\
\hline
\end{tabular}

${ }^{a}$ Not applicable because result is below indicated detection limit.

${ }^{b}$ Either the measurement was not attempted or the specie was not detected. 


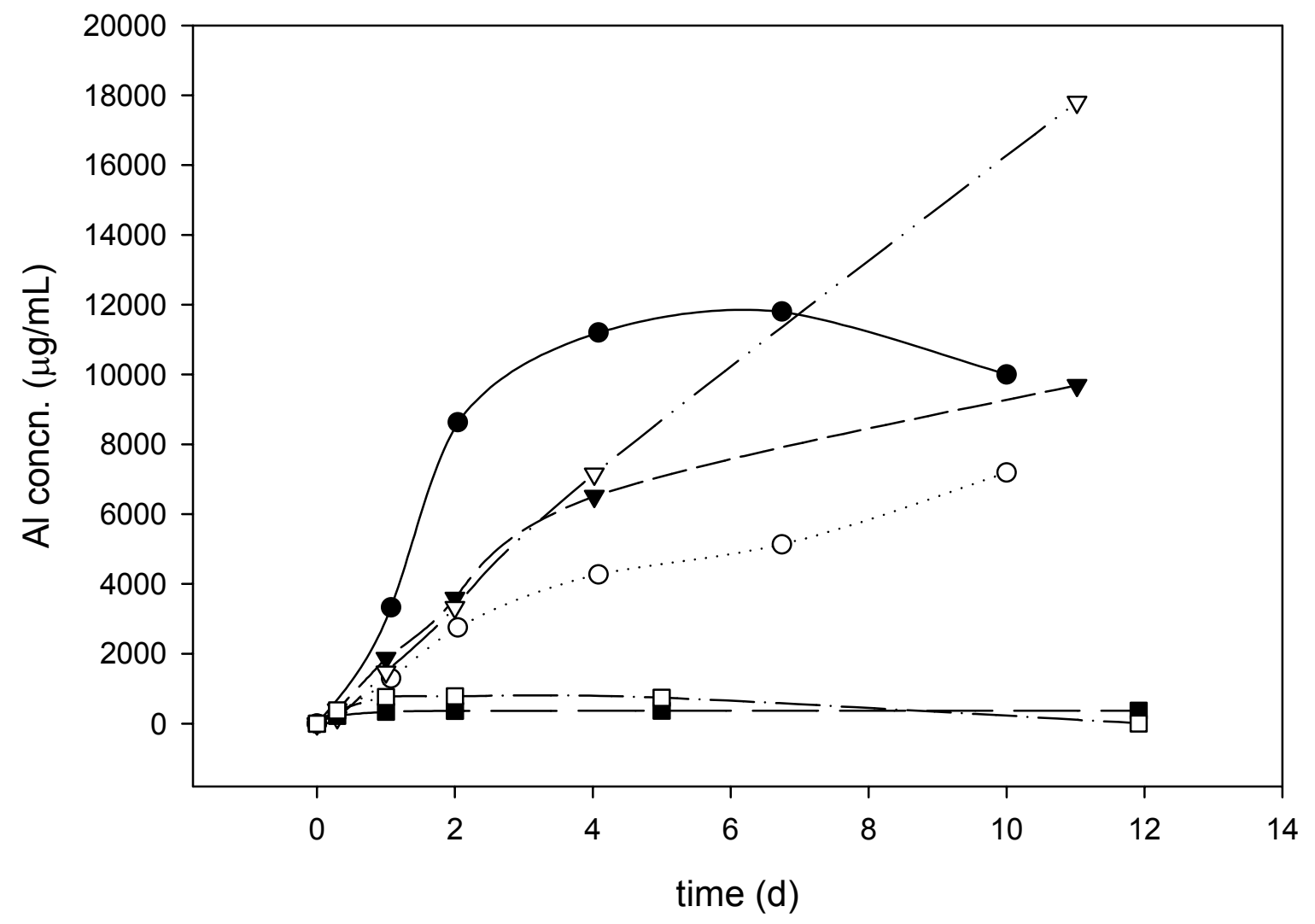

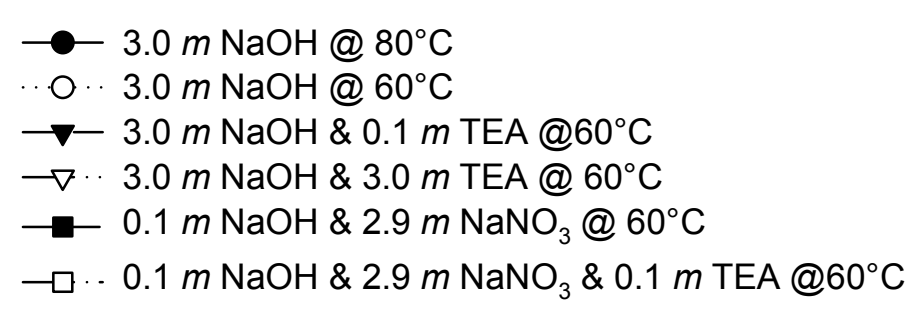

Fig. 4.1. Aluminum concentration in the leachates as a function of time.

\subsubsection{Dissolution of Other Metals}

Generally the filtered leaching solutions appeared as clear, light-yellow liquids. One exception was the leachate in sample \#8, which contained the high TEA-NaOH concentrations. This solution had a distinct green color, which deepened as the leaching time increased. Photographs of the liquid samples obtained in tests with $3.0 \mathrm{~m} \mathrm{NaOH}-0.1 \mathrm{~m}$ TEA and $3.0 \mathrm{~m}$ $\mathrm{NaOH}-3.0 \mathrm{~m}$ TEA (samples $\# 9$ and \#8, respectively) are shown in Fig 4.2. 
Small amounts of process metals were dissolved by the leaching solutions. Their concentrations were generally three or four orders of magnitude smaller than the concentration of

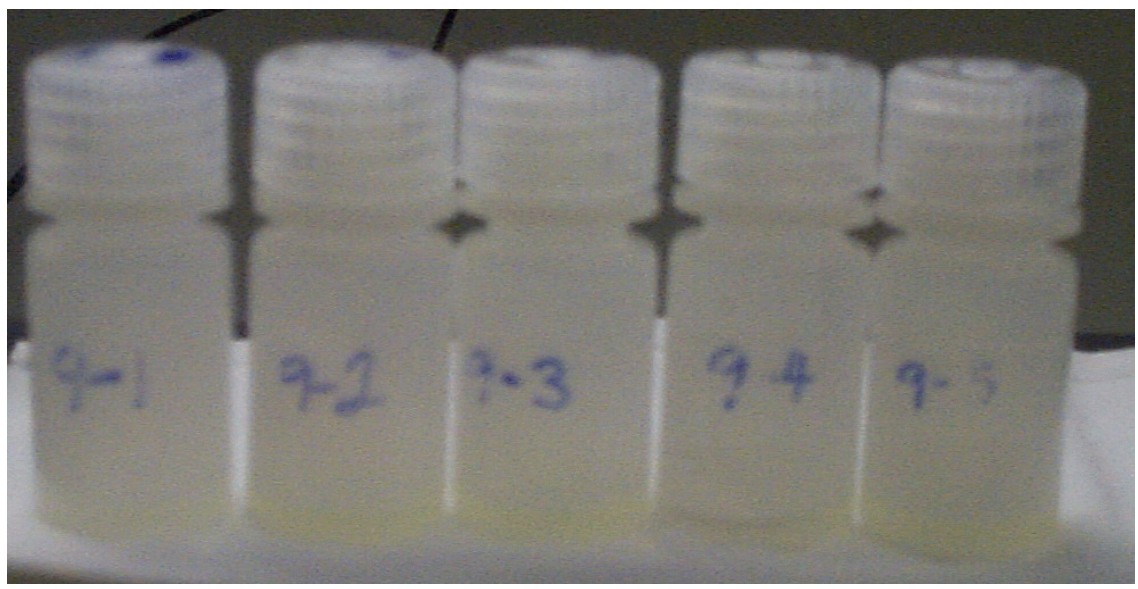

(a) Using $3.0 \mathrm{~m} \mathrm{NaOH}-0.1 \mathrm{~m}$ TEA

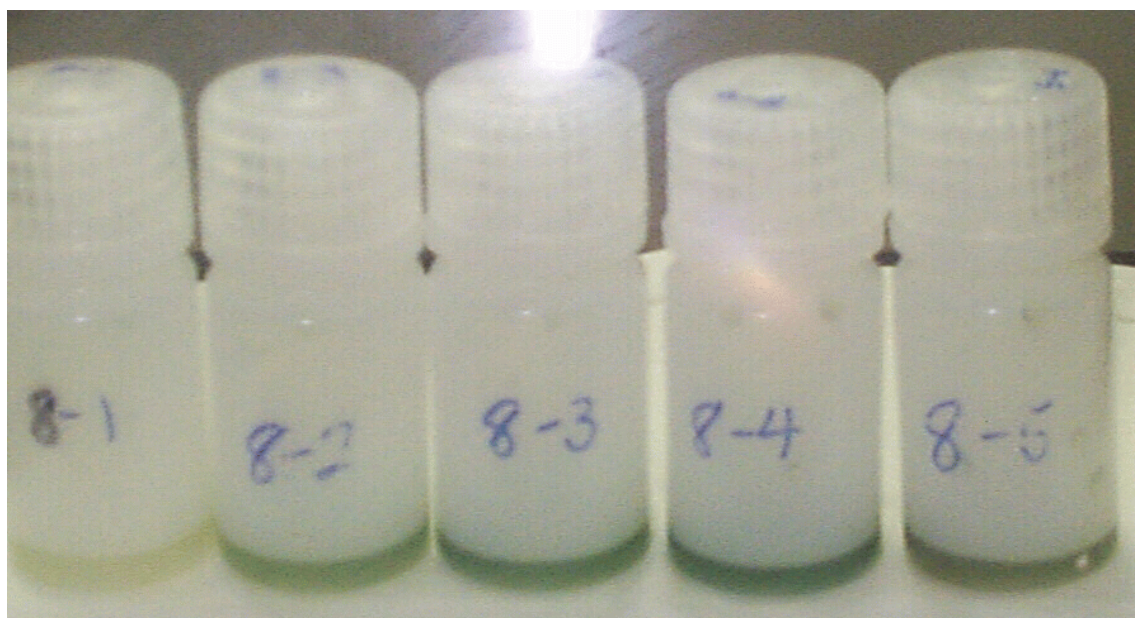

(b) Using $3.0 \mathrm{~m}$ NaOH$-3.0 m$ TEA

Fig. 4.2. Photographs of leachates showing (a) the typical lightyellow color and (b) the green color produced by high TEA concentration.

aluminum. The concentrations of the metals iron, nickel, and copper showed a correlation with TEA concentration. Because chromium did not dissolve to any appreciable extent, it was thought that the green color arose from dissolution of nickel. Figure 4.3 shows how the nickel concentration increased during the leaching of sludge (sample \#8) using a solution of $3.0 \mathrm{~m} \mathrm{NaOH}-3.0 \mathrm{~m}$ TEA. The nickel concentration saturated at - 4 days. Although - $13 \%$ of the nickel was removed from the sludge, nickel represents only $-0.72 \%$ of the mass of the dry sludge. There is independent direct evidence that TEA greatly enhances dissolution of nickel and copper oxides (Palmer 2002). 
The iron in the sludge was dissolved only when TEA was present. Figure 4.4 shows that the concentration of iron in the leachate increased with both the $\mathrm{NaOH}$ and TEA concentrations at a fixed temperature of $60 \mathrm{EC}$. Iron concentration reached a limiting value within - 2 days when the TEA concentration was $0.1 \mathrm{~m}$, but it continued to rise throughout the 11-day experiment when the

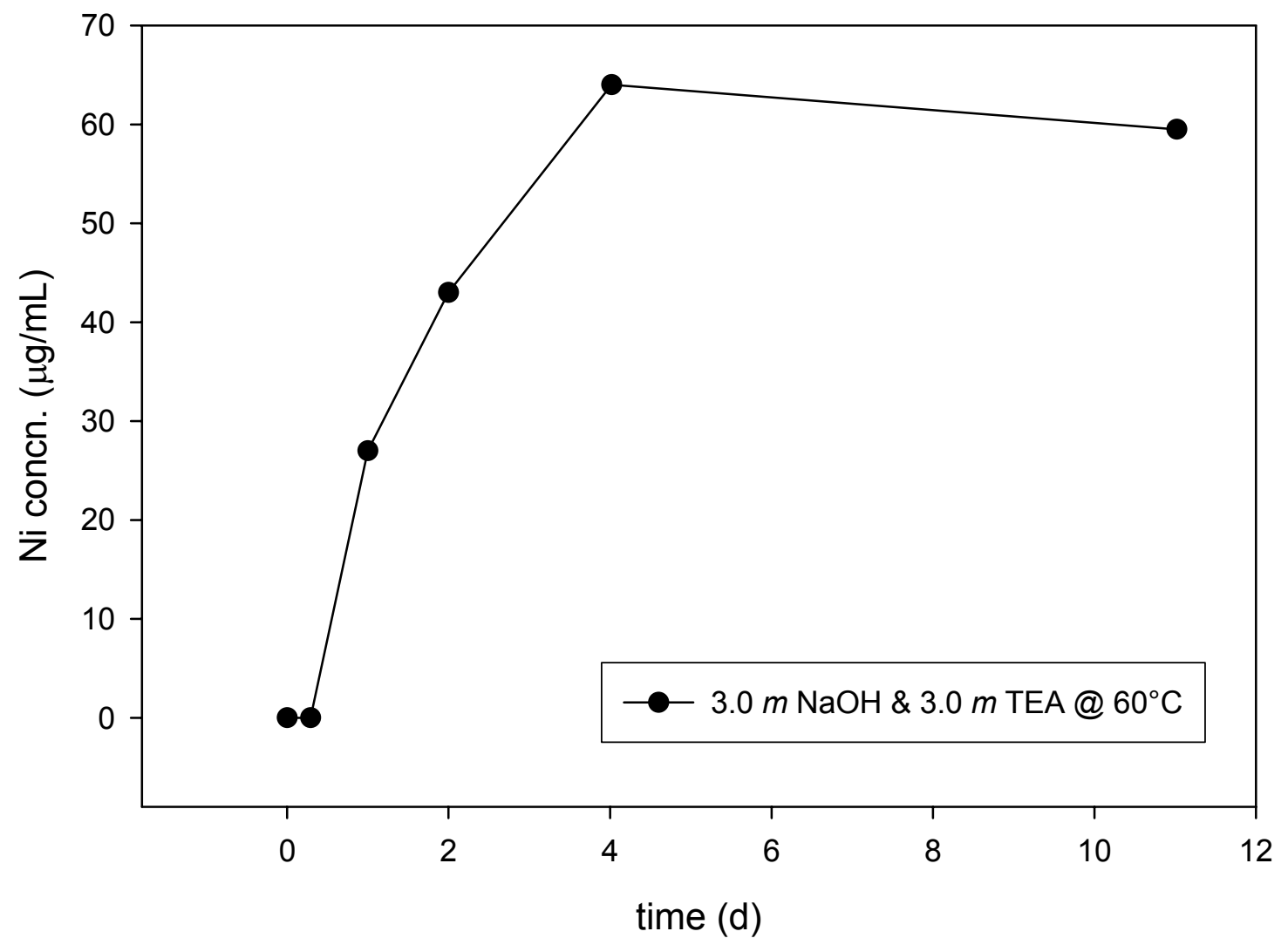

Fig. 4.3. Leaching of nickel at the higher concentration of TEA.

TEA concentration was $3.0 \mathrm{~m}$. Iron represents $-3.1 \%$ of the mass of dry sludge. When $3.0 \mathrm{~m}$ $\mathrm{NaOH}-0.1 \mathrm{~m}$ TEA was used, $-21 \%$ of the iron dissolved; however, no detectable amount of iron dissolved when $3.0 \mathrm{~m} \mathrm{NaOH}$ was used alone. The solution containing $0.1 \mathrm{~m} \mathrm{NaOH}-2.9 m \mathrm{NaNO}_{3}$ dissolved $-5 \%$ of the iron when the TEA was present at $0.1 \mathrm{~m}$. The solution containing $3.0 \mathrm{~m}$ $\mathrm{NaOH}-3.0 \mathrm{~m}$ TEA dissolved $52 \%$ of the iron in the sludge in 11 days, with the expectation that even more iron would dissolve with additional time. 


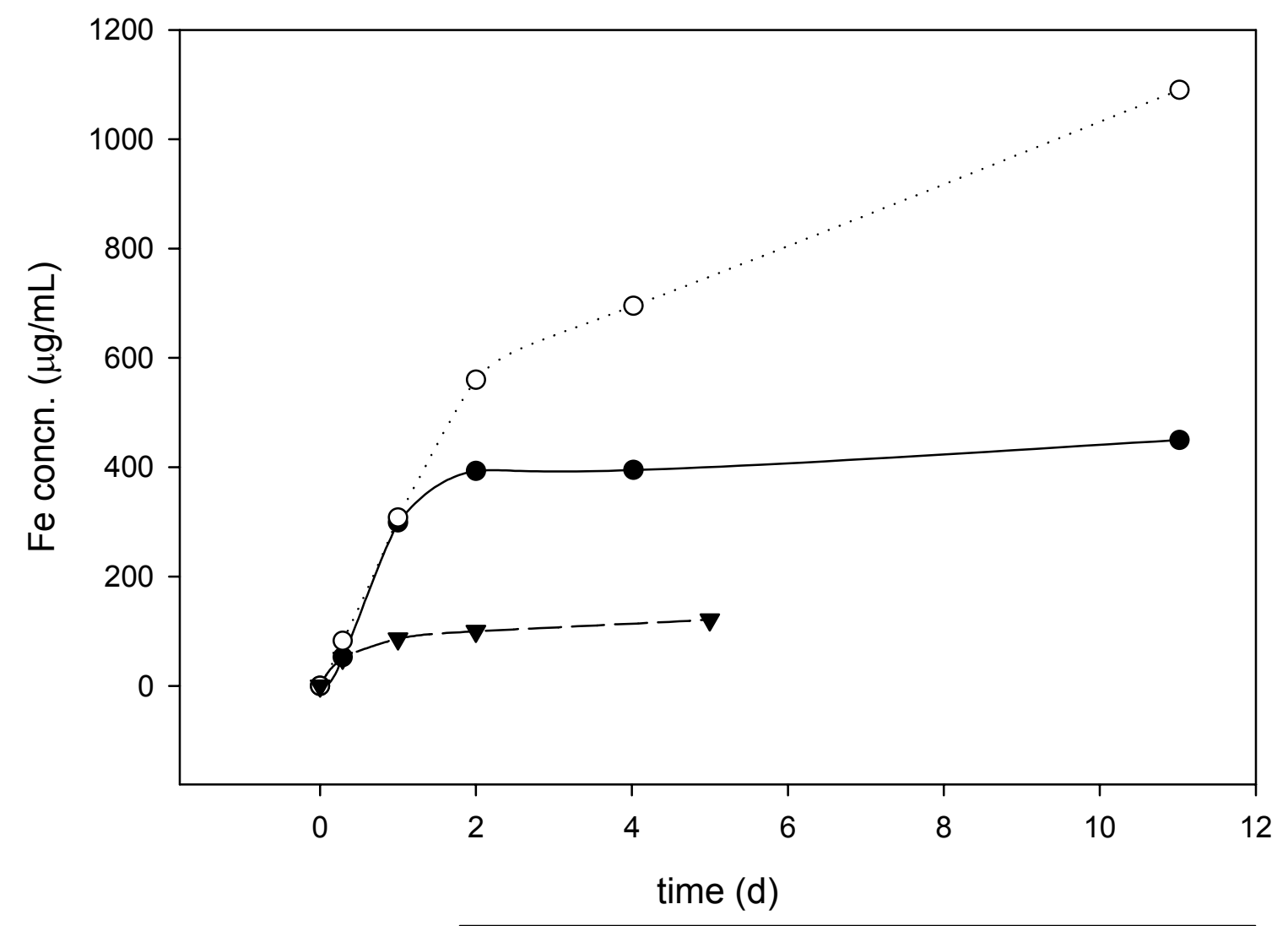

- $3.0 \mathrm{~m} \mathrm{NaOH} \& 0.1 \mathrm{~m}$ TEA @ $60^{\circ} \mathrm{C}$

$3.0 m \mathrm{NaOH} \& 3.0 \mathrm{~m}$ TEA @ $60^{\circ} \mathrm{C}$

$\rightarrow-0.1 m \mathrm{NaOH} \& 2.9 m \mathrm{NaNO}_{3} \& 0.1 \mathrm{~m}$ TEA @ $60^{\circ} \mathrm{C}$

Fig. 4.4. Iron concentration in the leachates, showing increases with addition of TEA.

Copper was leached from the sludge at the higher concentrations of $\mathrm{NaOH}$ (i.e., $3.0 \mathrm{~m}$ ) and when TEA was present. Figure 4.5 shows the results from the tests in which copper was measured in the leachates. Concentrations of copper were just above the limits of detection in those tests in which the leaching solution was caustic alone. At the baseline condition of $3.0 \mathrm{~m} \mathrm{NaOH}$ and $60 \mathrm{EC}$, - $14 \%$ of the copper was removed. In the experiment in which $0.1 \mathrm{~m}$ TEA was used with a highnitrate leach solution (i.e., $0.1 \mathrm{~m} \mathrm{NaOH}$ and $2.9 \mathrm{~m} \mathrm{NaNO}_{3}$ ), copper was not detected in the leachate. At $\mathrm{NaOH}$ concentrations of $3.0 \mathrm{~m}$, the copper concentration saturated in - 2 days when the TEA concentration was $0.1 \mathrm{~m}$ and continued to increase throughout the 11-day test when the TEA concentration was $3.0 \mathrm{~m}$. In the latter case $-72 \%$ of the copper dissolved, but this quantity is insignificant, considering that the dry sludge is only $-0.055 \%$ copper by mass. 


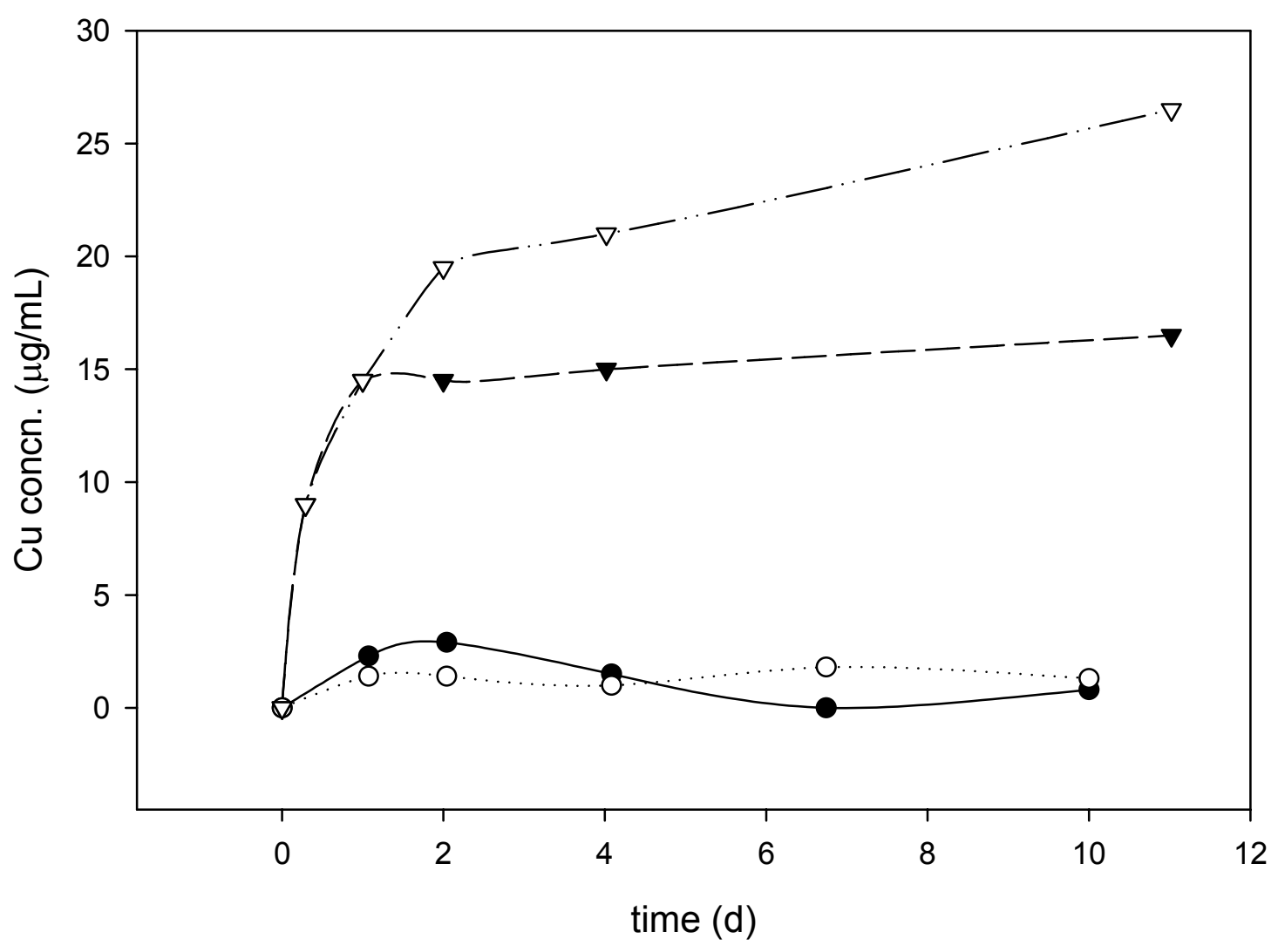

- $3.0 \mathrm{~m} \mathrm{NaOH} @ 80^{\circ} \mathrm{C}$

o. $3.0 \mathrm{~m} \mathrm{NaOH} @ 60^{\circ} \mathrm{C}$

$\rightarrow-3.0 \mathrm{~m} \mathrm{NaOH} \& 0.1 \mathrm{~m}$ TEA $@ 60^{\circ} \mathrm{C}$

$\rightarrow \cdots 3.0 m \mathrm{NaOH} \& 3.0 \mathrm{~m}$ TEA $@ 60^{\circ} \mathrm{C}$

Fig. 4.5. Leaching of copper in $3.0 \mathrm{~m} \mathrm{NaOH}$, showing increases with addition of TEA.

\subsubsection{Dissolution of Radionuclides}

The radionuclides detected in the leachate solutions were ${ }^{137} \mathrm{Cs},{ }^{60} \mathrm{Co}$, and ${ }^{154} \mathrm{Eu}$. Because of its lower concentration in the sludge, ${ }^{155} \mathrm{Eu}$ was sometimes, but not always, detected. Concentration profiles for these radionuclides are shown in Figs. 4.6 through 4.8. Cesium-137 was found in all leachates, as expected. The wet sludge samples contained interstitial liquid containing ${ }^{137} \mathrm{Cs}$. The data in Fig. 4.6 show that the equilibrium concentration of ${ }^{137} \mathrm{Cs}$ varies with the concentration of ingredients in the leach solution. The lowest concentrations of ${ }^{137} \mathrm{Cs}$ were measured in the $0.1 \mathrm{~m}$ 

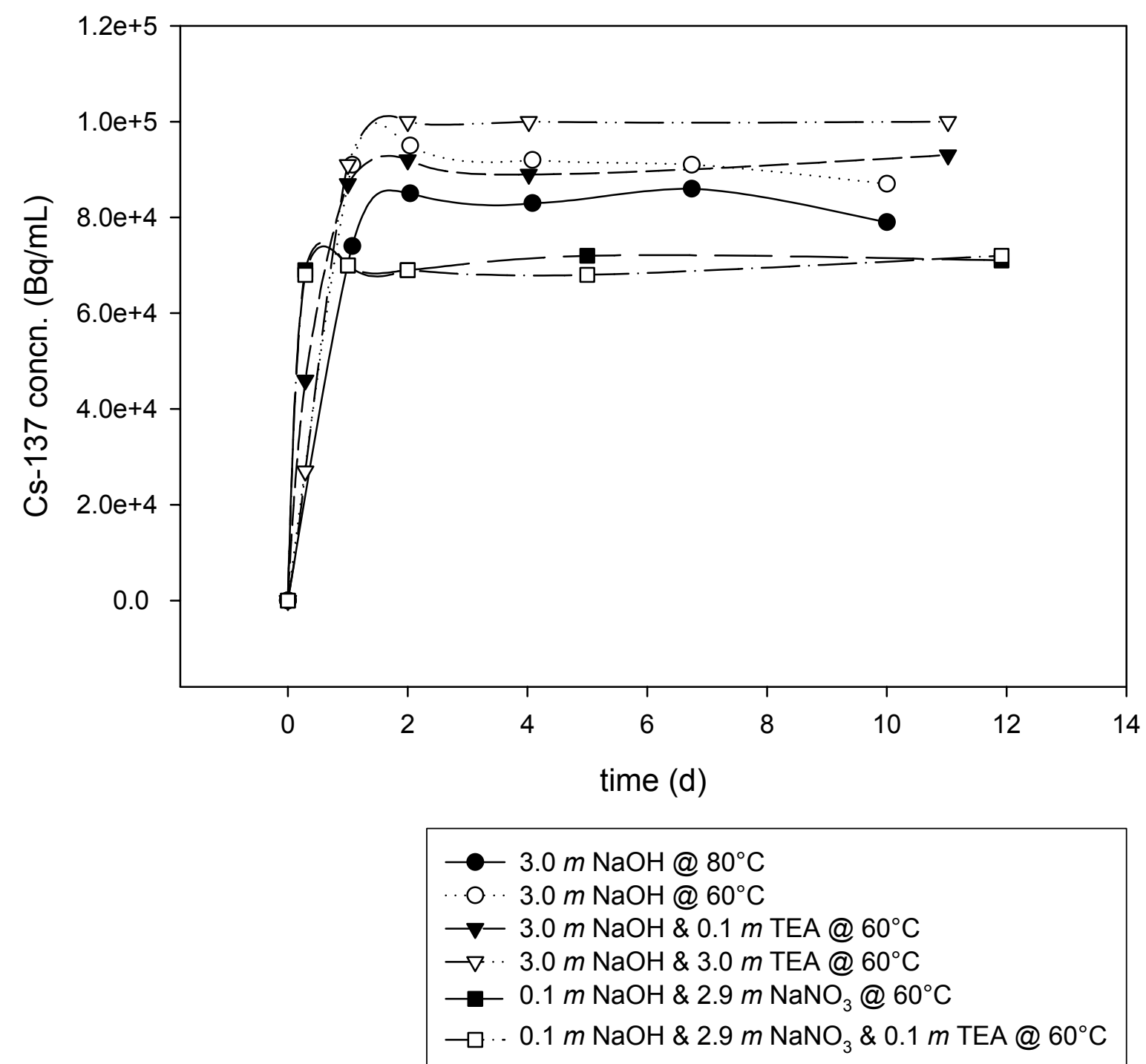

Fig. 4.6. Concentration of ${ }^{137} \mathrm{Cs}$ in leachates of all tests.

$\mathrm{NaOH}-2.9 m \mathrm{NaNO}_{3}$ leachates, with no significant difference occurring when the solution contained $0.1 \mathrm{~m}$ TEA. At these conditions $-69 \%$ of the remaining ${ }^{137} \mathrm{Cs}$ was removed from the washed sludge. Previous studies (Hunt et al., 1998) indicate that up to $72 \%$ of the ${ }^{137} \mathrm{Cs}$ may be removed from sludge by washing several times with inhibited water. Since only two washing steps were used during the preparation of the sludge in the present tests, it is reasonable to expect that part of the ${ }^{137} \mathrm{Cs}$ would have been removed by further washing without using leaching agents. When leaching with $3.0 \mathrm{~m}$ $\mathrm{NaOH}$ alone, increasing the temperature to $80 \mathrm{EC}$ decreased the equilibrium concentration of ${ }^{137} \mathrm{Cs}$ compared with the concentrations measured at $60 \mathrm{EC}$. The addition of $0.1 \mathrm{~m}$ TEA to $3.0 \mathrm{~m} \mathrm{NaOH}$ had no significant effect on the dissolution of cesium at $60 \mathrm{EC}$. The highest concentrations of cesium 
were measured in the leachate solution with $3.0 \mathrm{~m}$ TEA. The data indicate that $-96 \%$ of the ${ }^{137} \mathrm{Cs}$ remaining in the washed sludge was removed. Evidently, the enhanced dissolution of aluminum compounds with high caustic and TEA physically releases cesium, which readily enters solution. In all cases, the concentration of cesium rapidly increased and reached equilibrium in - 2 days or less.

Cobalt-60 was measured in leachates from two tests in which TEA was present, as illustrated in Fig. 4.7. The ${ }^{60} \mathrm{Co}$ concentrations are just above the detection limit in samples from the leaching test using $0.1 \mathrm{~m} \mathrm{NaOH}-2.9 \mathrm{~m} \mathrm{NaNO}_{3}-0.1 \mathrm{~m}$ TEA. Other experiments may have resulted in a similar amount of ${ }^{60} \mathrm{Co}$ dissolution (e.g., the test using $3.0 \mathrm{~m} \mathrm{NaOH}-0.1 \mathrm{~m}$ TEA); however, differences in the dilution factors during analysis could have reduced the values below the detection limits.

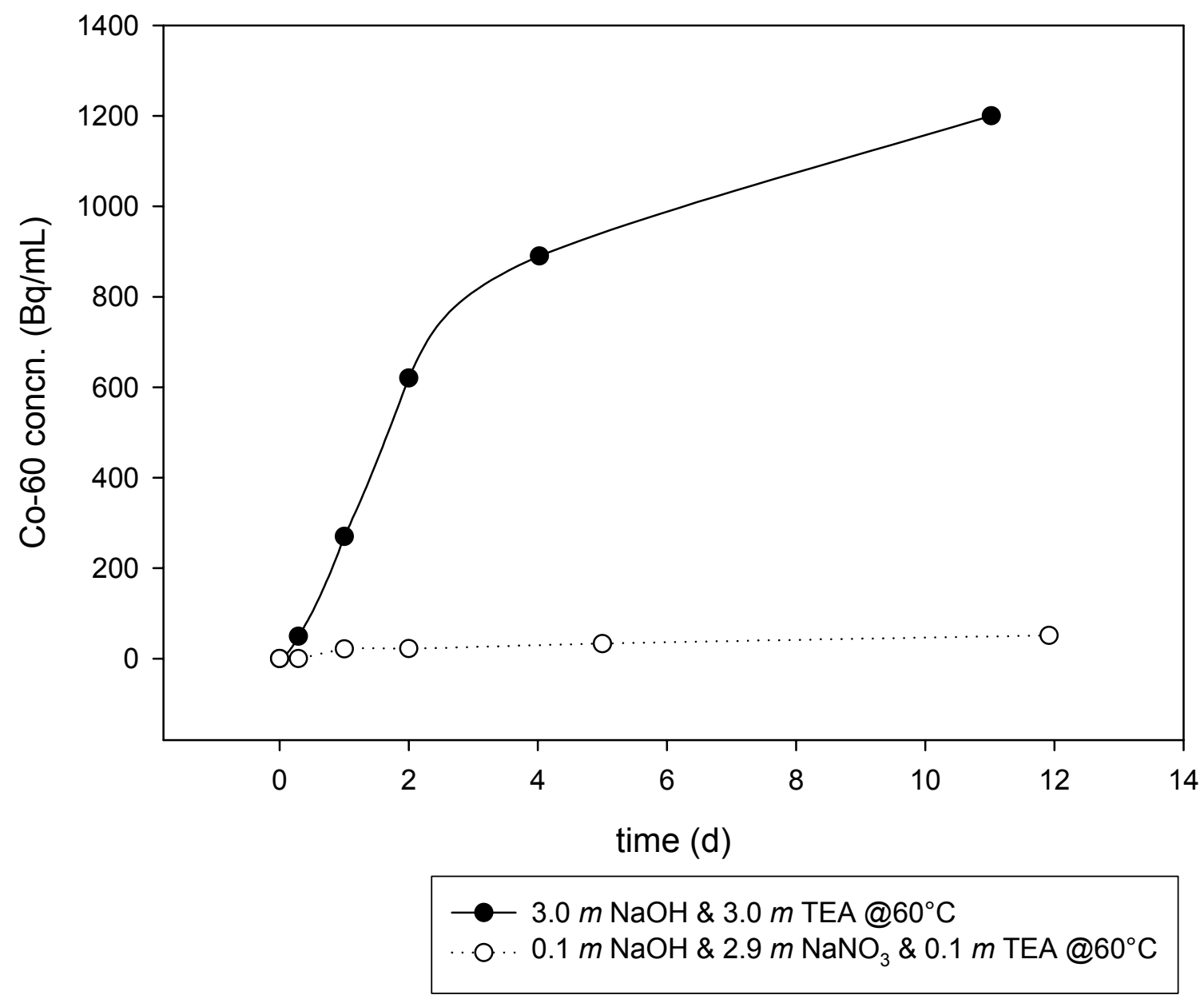

Fig. 4.7. Leaching of ${ }^{60} \mathrm{Co}$ at the higher concentrations of TEA.

The samples from leaching tests using $3.0 \mathrm{~m}$ NaOH-3.0 $\mathrm{m}$ TEA unambiguously show that cobalt is removed from the sludge. The period of most rapid rise in ${ }^{60} \mathrm{Co}$ concentration occurred in 
the first 2 days, and the concentration continued to rise throughout the 11-day experiment. Approximately $53 \%$ of the ${ }^{60} \mathrm{Co}$ was dissolved from the sludge when $3.0 \mathrm{~m}$ TEA was used. Because the overall cobalt concentration (radioactive and stable) in the sludge is below the detectable limits using ICP-AES analysis, the mass involved is negligible.

A small amount of europium was leached from the sludge when it was treated with a solution of $3.0 \mathrm{~m} \mathrm{NaOH}-3.0 \mathrm{~m}$ TEA. Figure 4.8 shows the measured ${ }^{154} \mathrm{Eu}$ concentration in the leachates as a function of time. The data indicate that the europium concentration initially rose very rapidly and then decreased to a steady value. One speculative explanation for this early maximum in the concentration profile is that the solubility limit of $\mathrm{Eu}(\mathrm{OH})_{3}$ was reached. An equilibrium concentration of europium was approached in - 2 days. At this concentration, only $-0.4 \%$ of europium present in sludge was dissolved.

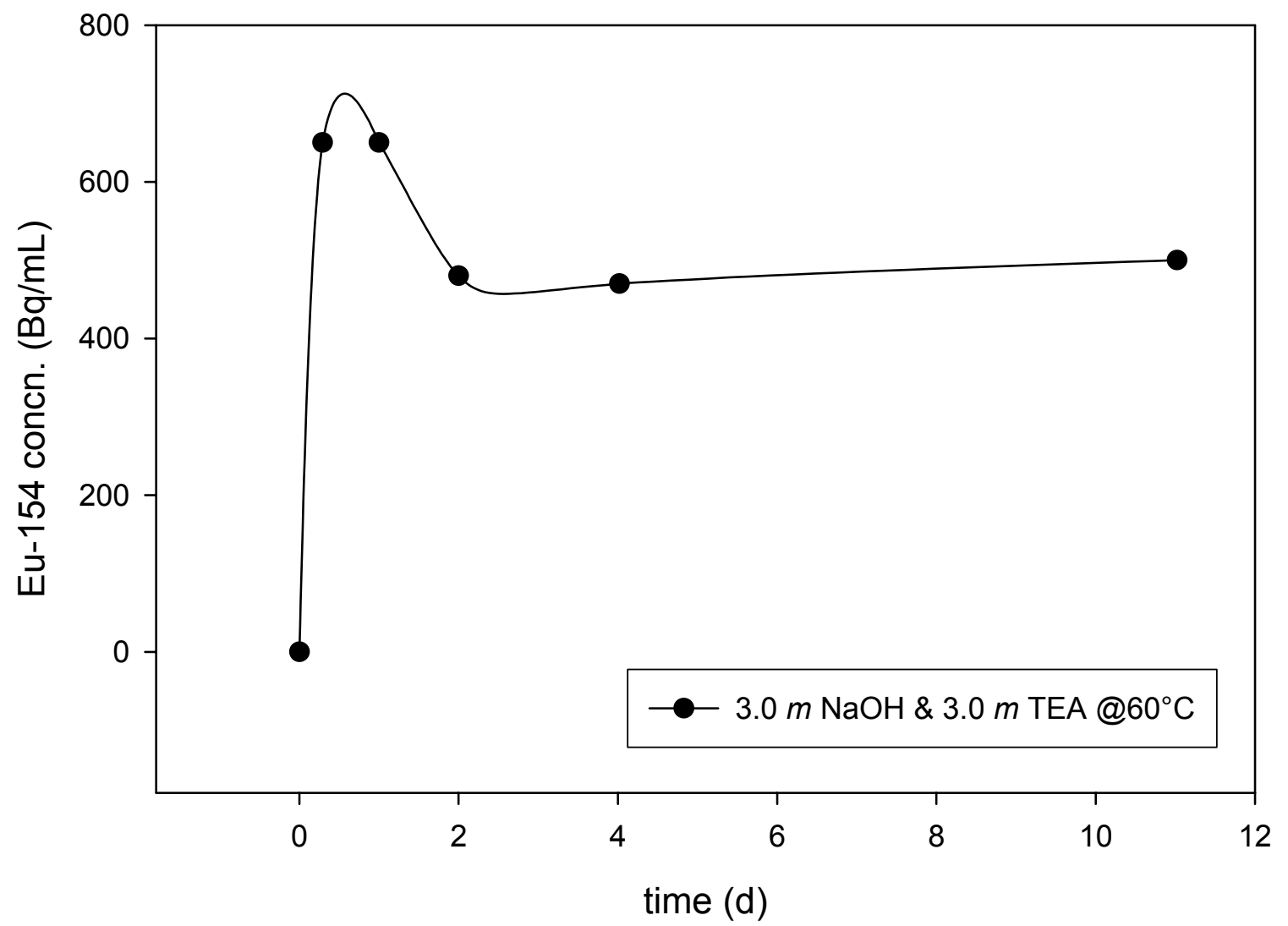

Fig. 4.8. Minor leaching of ${ }^{154} \mathrm{Eu}$ from the sludge at the higher concentration of TEA. 


\section{CONCLUSIONS AND RECOMMENDATIONS}

The primary objective of this study was to measure the effect of adding TEA to caustic leaching solutions to improve the solubility of aluminum in actual tank-waste sludge. HLW sludge that had a high aluminum assay was used for the tests. This waste, which originated with the processing of aluminum-clad/aluminum-alloy fuels, generates high levels of heat because of the high

${ }^{90} \mathrm{Sr}$ concentration and contains hard-to-dissolve boehmite phases. In concept, a chelating agent, such as TEA, can both improve the dissolution rate and increase the aluminum concentration in the liquid phase. For this reason, TEA could also increase the solubility of other sludge components that are potentially problematic to downstream processing. Tests were conducted to determine if this were the case. The high vapor pressure of the TEA at elevated temperatures must be considered during process design to keep losses low. General loss-control methods include sealed and/or pressurized systems (which are inappropriate for in-tank processing) or capture and recycle systems (which involve added process steps).

\subsection{CONCLUSIONS}

Sludge was retrieved from tank $12 \mathrm{H}$ at the SRS and shipped to ORNL for this study. The sludge contained a small quantity of rocky debris. One slate-like flat piece, which had approximate dimensions of $1 \frac{1}{4} \times 1 / 2 \times 1 / 8$ in., was recovered. Additional gravel-like fragments with approximate diameters ranging from $1 / 8$ to $1 / 4$ in. were also recovered by sieving the sludge slurry through a 1.4-mm square-pitch stainless steel mesh. These particles ranged from a yellow quartz-like material to grey-colored gravel. Of the $32.50 \mathrm{~g}$ of sludge received, the mass of the debris was only $0.89 \mathrm{~g}$, and the finely divided sludge comprised $-97 \%$ of the mass. The sludge was successfully subdivided into uniform aliquots during hot-cell operations. The smaller sludge samples were then used as needed for leaching experiments conducted in a glove box.

Six tests were performed with leachate concentrations ranging from 0.1 to $3.0 \mathrm{~m} \mathrm{NaOH}$, 0 to $3.0 \mathrm{~m}$ TEA and 0 to $2.9 \mathrm{~m} \mathrm{NaNO}_{3}$. One test was performed at an operating temperature of $80 \mathrm{EC}$ to obtain baseline data, and the remaining five tests were all performed at $60 \mathrm{EC}$. The two tests performed with a leaching solution of $3.0 \mathrm{~m} \mathrm{NaOH}$, at $60 \mathrm{EC}$ and $80 \mathrm{EC}$, indicated that more aluminum entered the solution at the higher temperature. Equilibrium was achieved at both temperatures within - 10 days. The addition of TEA significantly increased the concentration of aluminum in the leachate, and the concentration continued to increase even after 11 days of processing. The fraction of aluminum dissolved at $60 \mathrm{EC}$ increased from $-35 \%$ using $3.0 \mathrm{~m} \mathrm{NaOH}$ alone to $-87 \%$ using a combination of $3.0 \mathrm{~m} \mathrm{NaOH}$ and $3.0 \mathrm{~m}$ TEA. Leaching with solvents that had low hydroxide but high nitrate concentrations, both without TEA or with a small $(0.1 \mathrm{~m})$ TEA addition, did not significantly dissolve the aluminum.

Use of TEA also increased the solubility of some other sludge components. The fractions of copper, nickel, and iron that were dissolved increased to 72,13 , and $52 \%$, respectively. However, the original fractions of these metals were only $0.055,0.72$, and $3.1 \%$, respectively, of the dry mass of the sludge and therefore represent minor constituents. The presence of nickel in the leachate had a dramatic effect on its color as it changed from light yellow to deep green. By comparison, the 
baseline leaching with $3.0 \mathrm{~m} \mathrm{NaOH}$ at $60 \mathrm{EC}$ removed $-14 \%$ of the copper; nickel and iron were below the detectable limit.

The TEA also had a measurable effect on the solubility of the radionuclides ${ }^{137} \mathrm{Cs},{ }^{60} \mathrm{Co}$, and

${ }^{154} \mathrm{Eu}$. The presence of ${ }^{137} \mathrm{Cs}$ in the leachates was expected because of the ${ }^{137} \mathrm{Cs}$-bearing wash solution retained by the wet washed sludge and because of its high solubility in aqueous media. The high-nitrate leaches, which were the least effective of the leaching solutions, removed $69 \%$ of the ${ }^{137} \mathrm{Cs}$ from the washed sludge, while a combination of $3.0 \mathrm{~m} \mathrm{NaOH}$ and $3.0 \mathrm{~m}$ TEA removed $96 \%$. Very little ${ }^{60} \mathrm{Co}$ was removed from the sludge except with the use of the $3.0 \mathrm{~m} \mathrm{NaOH}-3.0 \mathrm{~m}$ TEA solution, which removed 53\%. This solution was also the only one that dissolved europium; however, only - $0.4 \%$ of the ${ }^{154} \mathrm{Eu}$ was removed from the sludge.

\subsection{RECOMMENDATIONS}

Adding TEA to the leaching solution significantly increased the removal of aluminum from the sludge. All the tests with TEA were performed at a temperature of $60 \mathrm{EC}$. Additional studies are recommended to obtain a better understanding of the effect of temperature on the leaching rate. Lower temperatures may be more appropriate for in-tank processing, whereas higher temperatures (and thus higher dissolution rates) may be more appropriate for out-of-tank processing. In either case, provisions should be made to minimize losses of the relatively volatile TEA. Further testing is also needed to evaluate optimal quantities of TEA required. For example, does the TEA need to be in great excess, or is a near-stoichiometric quantity with respect to aluminum sufficient? Engineering studies are recommended to evaluate process options, effects on materials of construction (especially for in-tank processes), safety concerns, and costs associated with the changes in the ESW process.

Nine well-characterized sludge samples and two other good samples, which could easily be characterized, are available for additional tests. These 11 samples can support the recommended test program or could be used to test other reagents. 


\section{ACKNOWLEDGMENTS}

This task was sponsored by the U.S. Department of Energy through the Office of Science and Technology's Tanks Focus Area under contract DE-AC05-00OR22725 with UT-Battelle, LLC. The work was performed at the Oak Ridge National Laboratory under the auspices of the Nuclear Science and Technology Division. 



\section{REFERENCES}

DeMuth, S. R., 1996. Estimating Heel Retrieval Costs for Underground Storage Tank Waste at Hanford, LA-UR-96-3038, Los Alamos National Laboratory.

Fondeur, F., 2001. Savannah River Site, personal communication to J. L. Collins, Oak Ridge National Laboratory, October 22.

Hunt, R. D., J. L. Collins, and C. W. Chase, 1998. Water Washes and Caustic Leaches of Sludge from Hanford Tank S-101 and Water Washes of Sludge from Hanford Tank C-103, ORNL/TM-13655, July.

Keller, J. M., J. M. Giaquinto, and A. M. Meeks, 1996. Characterization of the MVST Waste Tanks Located at ORNL, ORNL/TM-13357, Lockheed Martin Energy Research, Oak Ridge National Laboratory.

Lumetta, G. J., B. M. Rapko, M. J. Wagner, J. Liu, and Y. L. Chen, 1996. Washing and Caustic Leaching of Hanford Tank Sludges: Results of FY 1996 Studies, PNNL-11278, Battelle, Pacific Northwest National Laboratory.

Palmer, D. A., 2001. Oak Ridge National Laboratory, unpublished data, September.

Palmer, D. A., 2002. Oak Ridge National Laboratory, personal communication to B. B. Spencer, Oak Ridge National Laboratory, November 11.

U.S. Department of Energy, 1996. Integrated Database Report-1995: U.S. Spent Nuclear Fuel and Radioactive Waste Inventories, Projections, and Characteristics, DOE/RW-0006, Rev. 12. 

ORNL/TM-2002/195

\section{INTERNAL DISTRIBUTION}

1. R. T. Jubin

2-3. B. B. Spencer

4. ORNL Laboratory Records-CRL, RC, OSTI

\section{EXTERNAL DISTRIBUTION}

5. J. T. Bell, 137 Bowspirit Lane, Kingston, TN 37763

6. B. Z. Egan, 103 Lewis Lane, Oak Ridge, TN 37830

7. Louis Kovach, Hanford, P.O. Box 1970, K6-51, Richland WA 99352

8. Wally Schulz, W2S Company, 12704 Sandia Ridge Place, NE, Albuquerque, NM 87111

9. R. G. Wymer, 188-A Outer Drive, Oak Ridge, TN 37830

\section{ELECTRONIC DISTRIBUTION ONLY}

J. T. Carter, WSRC, joe.carter@sss.gov

B. A. Carteret, PNL, betty.carteret@pnl.gov

J. L. Collins, ORNL, collinsj1@ornl.gov

N. G. Colton, PNNL, penny.colton@pnl.gov

A. G. Croff, ORNL, croffag@,ornl.gov

S. D. Fink, WSRC, sam.fink@srs.gov

F. F. Fondeur, WSRC, fernando.fondeur@srs.gov

J. A. Frey, DOE-RL, jeffrey a frey@rl.gov

R. L. Gilchrist, PNL, rl.gilchrist@pnl.gov

D. T. Hobbs, WSRC, david.hobbs@srs.gov

H. D. Harmon, WSRC, harry.harmon@srs.gov

R. D. Hunt, ORNL, huntrd@ornl.gov

C. M. Kendrick, ORNL, kendrickcm@ornl.gov

R. A. Kirkbride, NHC, Randy A Kirkbride@rl.gov

B. E Lewis, Jr., ORNL, lewisbejr@ornl.gov

G. J. Lumetta, PNNL, gregg.lumetta@pnl.gov

C. P. McGinnis, ORNL, mcginniscp@,ornl.gov

J. R. Noble-Dial, DOE-OR, nobledialjr@ornldoe.gov

D. A. Palmer, ORNL, palmerda@ornl.gov

S. F. Piccolo, WSRC, stephen.piccolo@srs.gov

B. M. Rapko, PNNL, bryan.rapko@pnl.gov 
K. J. Rueter, WTP, kjrueter@bechtel.com

J. M. Simonson, ORNL, simonsonjm@ornl.gov

J. L. Swanson, PNNL, Ret., johnlswanson@worldnet.att.net

D. J. Temer, LANL, dtemer@lanl.gov

M. C. Thompson, WSRC, major.thompson@srs.gov

G. F. Vandegrift, III, ANL, vandegrift@cmt.anl.gov

T. D. Welch, ORNL, welchtd@ornl.gov

D. J. Wesolowski, ORNL, wesolowskid@ornl.gov 